EARLY-STAGE SOCIAL VENTURES:

RESOURCE ACQUISITION, CEO SELECTION, AND IMPACT INVESTORS

A Dissertation presented to the
$\begin{gathered}\text { Faculty of the Graduate School } \\ \text { University of Missouri }\end{gathered}$
In Partial Fulfillment
Of the Requirements for the Degree
Doctor of Philosophy
BAHYU OH
Dr. Karen A. Schnatterly, Dissertation Advisor

JULY 2018 
(C) Copyright by Nahyun Oh 2018

All Rights Reserved 
The undersigned, appointed by the Dean of the Graduate School, have examined the dissertation entitled

\section{EARLY-STAGE SOCIAL VENTURES: RESOURCE ACQUISITION, CEO SELECTION, AND IMPACT INVESTORS}

presented by Nahyun Oh, a candidate for the degree of Doctor of Philosophy of Business Administration, and hereby certify that in their opinion, it is worthy of acceptance.

Dr. Karen A. Schnatterly

Dr. Douglas D. Moesel

Dr. Lin Jiang

Dr. Randall E. Westgren 


\section{ACKNOWLEDGEMENTS}

I am grateful to all of those whom I have had a pleasure to work together during this journey. I would especially like to express the most profound appreciation to my dissertation chair and advisor Dr. Karen Schnatterly. She has been providing her invaluable guidance, inspiration, and support at all times. Without her guidance, this work would not have been possible, and I am eternally grateful to her for her assistance. I would like to give special thanks to my dissertation committee, Dr. Doug Moesel, Dr. Lin Jiang, and Dr. Randy Westgren for their warm support and insightful feedback and suggestions until this work came to existence. I also thank all my fellow doctoral students for their friendship and encouragement through this entire process. Last but not least, I would like to say a heartfelt thank my family and friends for encouraging me in all of my pursuits and inspiring me to follow my dreams. In particular, I am grateful to my parents for unconditional trust and endless emotional support. My sister and friends have always been generous with their love and encouragement despite the long distance between us. I sincerely thank all of them for helping me get through difficult moments and keep moving towards my goal. 


\section{TABLE OF CONTENTS}

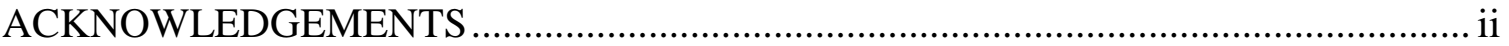

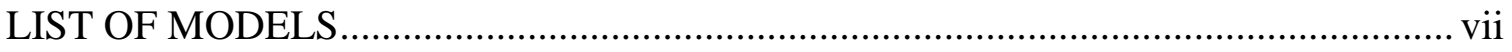

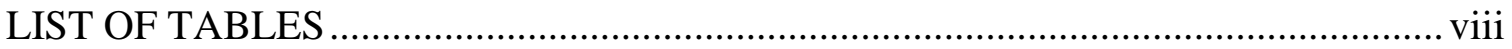

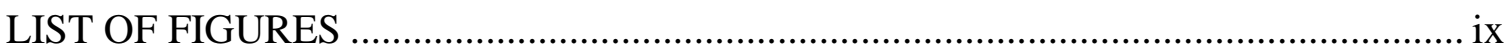

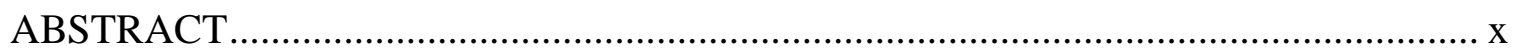

CHAPTER 1: INTRODUCTION ...................................................................... 1

CHAPTER 2: ASSESSING RESOURCES OF EARLY-STAGE SOCIAL VENTURES:

A SIGNALING THEORY PERSPECTIVE ON VENTURE PHILANTHROPY-

ORIENTED FOUNDATIONS' FUNDING DECISION ............................................ 4

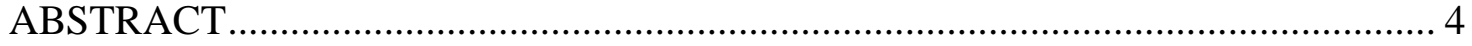

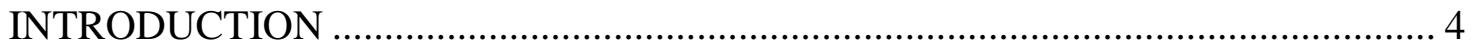

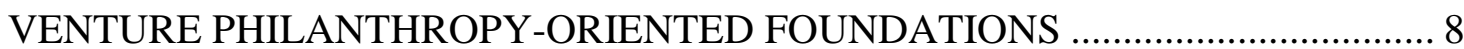

SIGNALS ACROSS THREE LEVELS: CORE FOUNDER, FOUNDING TEAM,

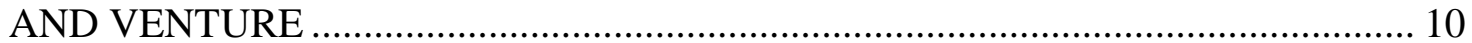

Information Asymmetry and Signaling Theory .............................................. 10

Core Founders' Breadth of Knowledge, Founding Teams' Functional Diversity, and

Funding from Venture Philanthropy-oriented Foundations................................. 11

Social Ventures’ Entrepreneurial Orientation (EO) and Mission Alignment on

Funding from Venture Philanthropy-oriented Foundations................................. 15 
THE FORMATION OF SOURCES OF SIGNALS ACROSS THREE LEVELS ...... 19

The Importance of Core Founders' Initial Decisions ............................................. 19

Core Founders' Breath of Functional Knowledge and Founding Team Formation . 20

The Moderating Role of Core Founders' Direct Personal Experience with a Focal

Social Problem

The Influence of Founding Teams’ Dominant Function Diversity on Social

Ventures' Entrepreneurial Orientation (EO) and Mission Alignment ..................... 28

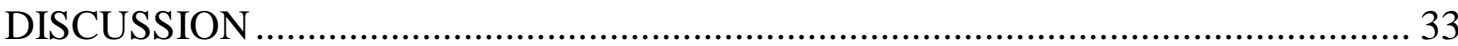

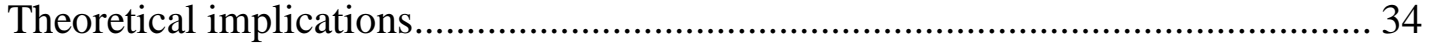

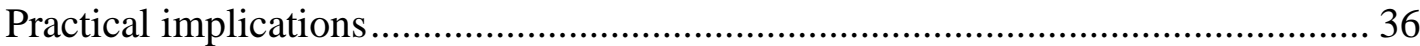

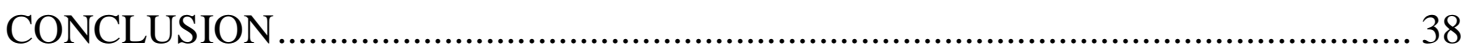

CHAPTER 3: LEADERSHIP EMERGENCE IN EARLY-STAGE SOCIAL VENTURES: HOW DOES THE FOUNDING TEAM SELECT THE FIRST CEO? .... 39

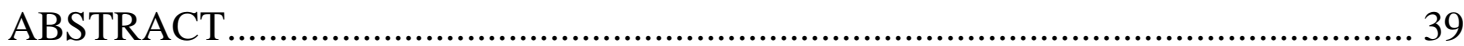

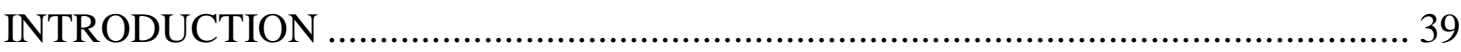

THEORETICAL BACKGROUNDS AND HYPOTHESES ................................. 43

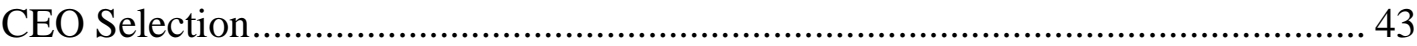

Human Capital Theory and Social Entrepreneurship .......................................... 45

Prior Commercial Experience and Leadership Emergence .................................... 47

Prior Social Experience and Leadership Emergence ............................................. 49 
Balanced Entrepreneurs and Leadership Emergence.

Gender Stereotypes in Business, Entrepreneurship, and Leadership Emergence..... 51

Moderating Influence of Gender on Leadership Emergence ................................. 54

Gender of Balanced Entrepreneurs and Leadership Emergence........................... 58

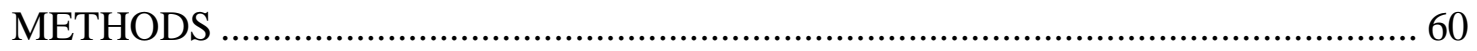

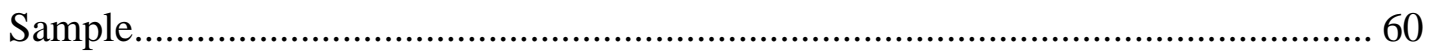

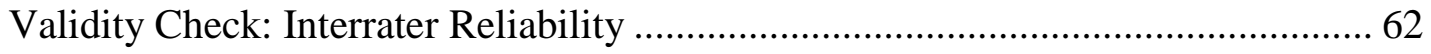

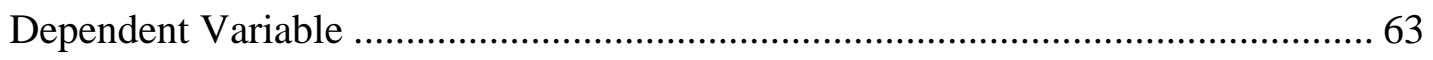

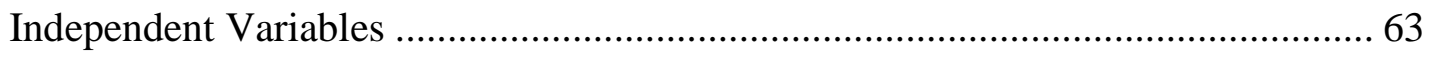

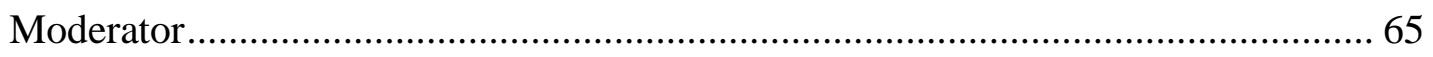

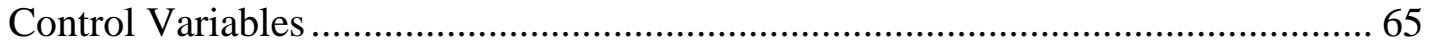

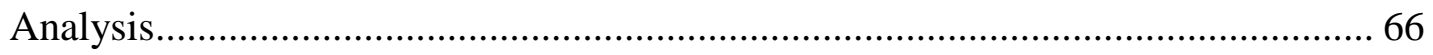

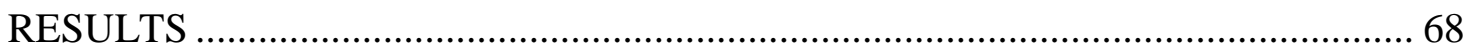

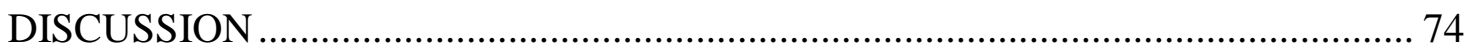

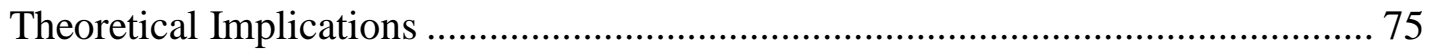

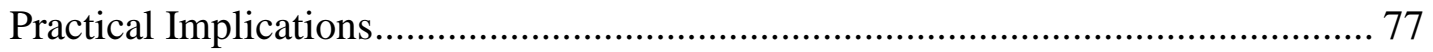

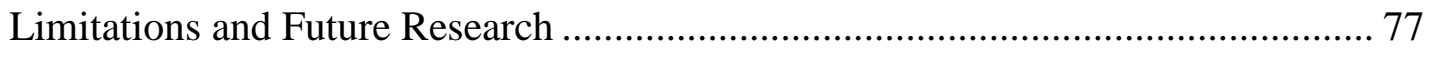

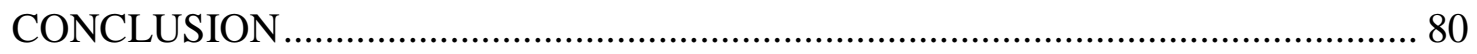

CHAPTER 4: ECHOING GREEN'S SURVIVAL STRATEGY AFTER THE

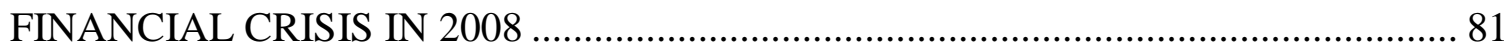


INTRODUCTION

ECHOING GREEN'S EARLY HISTORY

STRATEGIC CHANGES AFTER THE FINANCIAL CRISIS: FROM A SINGLE

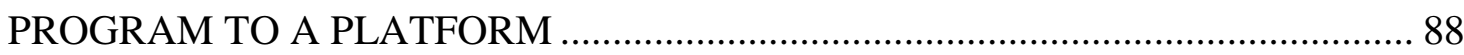

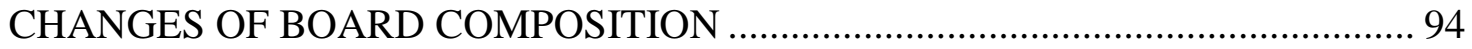

CHANGES IN CHARACTERISTICS OF FELLOWS ............................................... 97

IMPLICATIONS OF ECHOING GREEN'S STRATEGIC CHOICE ....................... 99

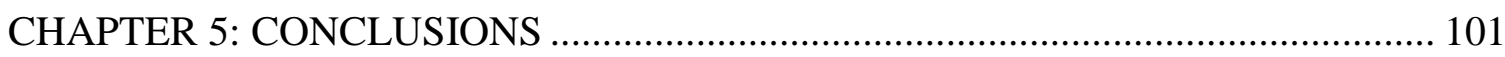

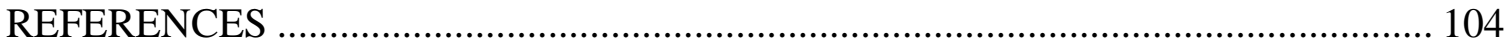

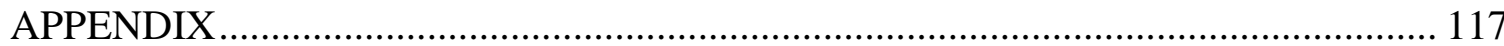

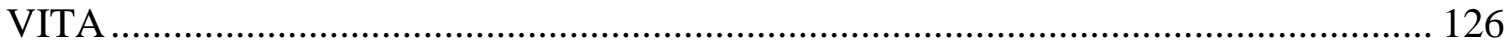




\section{LIST OF MODELS}

CHAPTER 2: Model 1: A Theoretical Model of Early-stage Social Venturs' Fundraising

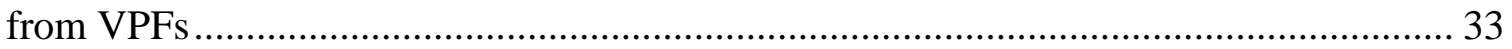

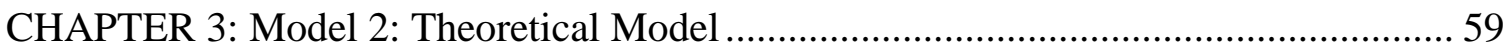




\section{LIST OF TABLES}

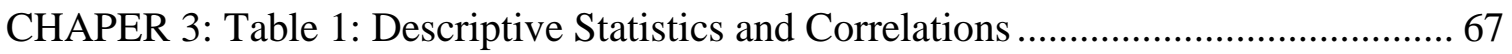

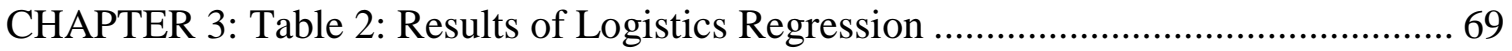

CHAPTER 4: Table 3: Summary of Financial Data (\$, except the number of donors and public support percentage; fiscal year ends June 30 of the year indicated) .................... 84

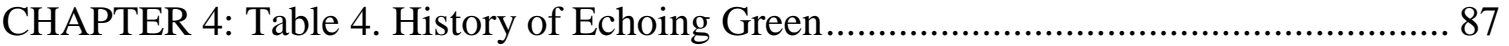

CHAPTER 4: Table 5. Major Donators (Represents donors who contributed $\$ 500,000$ or

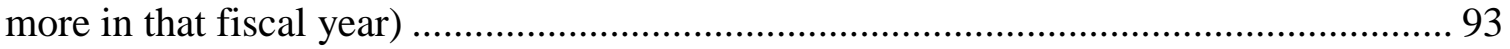




\section{LIST OF FIGURES}

CHAPTER 3: Figure 1: Main Effects of Social Experience on the Predicted Probability of becoming CEO 68

CHAPTER 3: Figure 2: Interaction Effects of Commercial experience and Gender on the

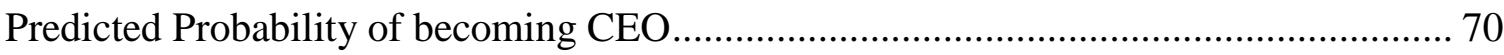

CHAPTER 3: Figure 3: Interaction Effects of Commercial Experience and Female

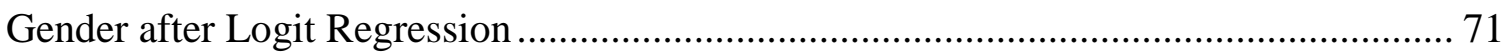

CHAPTER 3: Figure 4: Interaction Effects of Social Experience and Female Gender after

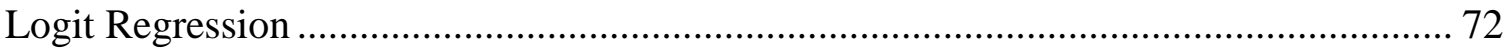

CHAPTER 3: Figure 5: Interaction Effects of Balanced Entrepreneur and Female Gender

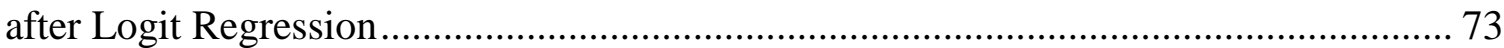

CHAPTER 4: Figure 6. Echoing Green Fellows' Organization Model (2008-2017) ...... 89

CHAPTER 4: Figure 7. Number of Fellows Selected by Year and Organization Model 90

CHAPTER 4: Figure 8. GDP growth of the United States from 2008-2017.................... 90

CHAPTER 4: Figure 9. Board of Directors of Echoing Green (2008-2017) ................... 96

CHAPTER 4: Figure 10. Issue Areas of Echoing Green Fellows by Year ....................... 98 


\title{
EARLY-STAGE SOCIAL VENTURES: RESOURCE ACQUISITION, CEO SELECTION, AND IMPACT INVESTORS
}

\author{
Nahyun Oh \\ Dr. Karen A. Schnatterly, Dissertation Advisor
}

\begin{abstract}
In this dissertation, I explore early-stage social ventures' resource acquisition, the first CEO selection, as well as how funding foundations supporting early-stage social ventures overcome challenges emerge from the economic crisis. Social ventures are organizations established by social entrepreneurs who seek to create social impact by providing systematic and sustainable solutions. They pursue the integration of social mission and economic goal in organizations' core, thus are distinguished from both commercial organizations and nonprofits. Successful acquisition of seed capital and the first CEO selection are crucial milestones for social ventures to survive and flourish. The proposed model in Chapter 2 suggested factors of social ventures that affect impact investor's eventual investment decision. It explicates how characteristics of a core founder, a founding team, and a social venture relate to each other and contribute to the increasing possibility of seed capital acquisition. Chapter 3 of this dissertation examines the first CEO selection of social venture. I empirically tested hypotheses using a dataset of 261 social entrepreneurs from 108 social ventures and found that previous working experience in social mission-oriented organizations is crucial for being assigned as the first CEO. Additionally, previous working experience in commercial firms contributes to only female social entrepreneurs' possibility of becoming the first CEO. In Chapter 4, I
\end{abstract}


shift the focus to impact investors and explore the survival strategy of a funding foundation, Echoing Green, in response to financial challenges during the economic downturn in 2008. 


\section{CHAPTER 1: INTRODUCTION}

Social ventures entail the application of business models to resolve social problems, such as poverty, food insecurity, and pollution (Battilana \& Lee, 2014; Wry \& York, 2017). The joint pursuit of social mission and financial goal distinguishes social ventures from both commercial ventures where prioritize economic profits and nonprofits that solely rely on financial inputs from donors (Dees, 1998; Dees \& Anderson, 2003; Ebrahim, Battilana, \& Mair, 2014; Wry \& York, 2017). Due to this unique feature, social ventures have been of interest to organizational scholars (Dacin, Dacin, \& Matear, 2010). So far, most of the academic attention in the field of social entrepreneurship has given to the challenges social ventures face when internal or external groups disagree with the logic that the organization should prioritize (Battilana \& Dorado, 2010; Ebrahim et al., 2014). Many research in social entrepreneurship has focused on how social ventures can effectively resolve the tensions arise from conflicting demands related to economic and social welfare logic (Wry \& York, 2017). While these studies provide useful insights to understand already established social ventures, research in early-stage social ventures are still emerging.

To extend our understanding about this understudied but promising topic, the current dissertation investigates resource acquisition and the first $\mathrm{CEO}$ selection, which are crucial events in the early-stage of social ventures that can have lasting impacts on the ventures' survival in future. Additionally, I explore funding organizations which offer early-stage social ventures financial and strategic support. It contributes to advance the 
understanding of the impact of funding organizations has on early-stage social ventures and the field of social entrepreneurship.

In Chapter 2 of this dissertation, I explore early-stage social ventures' acquisition of resources from venture philanthropy-oriented foundations (VPFs). VPFs are emerging as a major source of financing for social ventures in nascent stage. The fact of being selected as a fellow of prominent VPFs provide credibility to social entrepreneurs. As a result, it can highly improve social entrepreneurs' chance to obtain additional financial resources and strategic supports from other VPFs. Subsequently, social ventures' chance to survive and create continual social impact increases. However, we know little about which aspects of social ventures contribute to its success in fundraising from VPFs. Chapter 2 investigates the factors across core founder, founding team, and social venture level that amplify or attenuate the venture's possibility of obtaining support from VPFs. The suggested model also describes how these factors are related to each other.

Chapter 3 empirically investigates one of the critical milestones for social ventures, the first CEO selection. The role of the first CEO is crucial for early-stage social ventures' survival rate and future performance, as the first CEO paves the fundamentals for the venture, which have lasting effects. There are established literature on leadership emergence in leaderless groups, but not much academic attention has given to the first CEO selection of early-stage social venture founding team. Further, social ventures provide a unique context to explore leadership emergence due to their dualistic nature, pursuing both social mission and financial profits. In Chapter 3, I examine the criteria founding teams use when they select one of them as the first CEO of the social venture. Specifically, I focus on how factors related to prior occupational exposures and 
gender influence the CEO selection. The findings indicate that a founder's social experience largely affects his or her CEO assignment. Additionally, the results show that commercial experience only enhances a female social entrepreneur's likelihood of becoming the CEO. These findings demonstrate that early-stage social ventures tend to prioritize leader candidates' social experience above other occupational experiences in the first CEO selection, and positive violation of gender stereotype helps female founders become the first CEO.

In Chapter 4, I shift the focus to impact investors, explicitly funding foundations that primarily support organizations with social aim. This chapter is a qualitative case study about the Echoing Green Foundation, a New York City-based nonprofit public charity that selects promising social ventures and provides those with seed-capital and non-financial support annually. In this chapter, I investigate the Echoing Green's survival strategy in response to the financial crisis in 2008, which increased the demand for funding foundation's service while decreased financial inputs from donors. In particular, I examine how the Echoing Green improves its financial situation by collaborating with other private foundations and financial institutions. Also, I discuss how the Echoing Green's new partnerships affect its board construction and the consequent changes in the field of social entrepreneurship.

Overall, this dissertation discusses factors that contribute to early-stage social ventures' acquisition of funding, how early-stage social ventures select their first CEO, and how impact investors, significant supporters for social entrepreneurship, overcome external threats and how their survival strategy leads to following changes in the field of social entrepreneurship. 


\title{
CHAPTER 2: ASSESSING RESOURCES OF EARLY-STAGE SOCIAL VENTURES: A SIGNALING THEORY PERSPECTIVE ON VENTURE PHILANTHROPY-ORIENTED FOUNDATIONS' FUNDING DECISION
}

\begin{abstract}
Venture philanthropy-oriented foundations (VPFs) have an increasing impact on social entrepreneurship by supporting social ventures with creative ideas to solve social problems. However, we know little regarding which aspects of social ventures contribute to raising funds from VPFs and how these aspects are created during social ventures' formation. To extend our understanding of this topic, this article provides a theoretical framework that explicates how social ventures' key signals to prospective lenders, specifically VPFs, are created and work. Deriving insights from signaling theory, this article theorizes that direct influence of core founders' breadth of functional knowledge, founding teams' dominant function diversity, and social ventures' entrepreneurial orientation and mission alignment on social ventures' likelihood of obtaining seed capital from VPFs. Utilizing insights from the research on social imprinting, entrepreneurial team-building, and team diversity, the model also illustrates how a core founder's breadth of knowledge and personal experience with a focal social problem affect his or her criteria on founding team member selection and eventually shape the level of entrepreneurial orientation and mission alignment of new social ventures.
\end{abstract}

\section{INTRODUCTION}

Venture philanthropy-oriented foundations (VPFs) are emerging as one of the primary sources of seed capital for early-stage social ventures that seek to provide 
systematic solutions to social problems. To date, prominent VPFs demonstrate growing influence in social entrepreneurship by investing in innovative ideas for creating genuine and long-lasting change in a society. In addition to financial resources, VPFs provide strategic support, mentorship, and advice for promising new social ventures to move forward to the next stage. For instance, the Echoing Green foundation has offered grants and necessary supports for early-stage social ventures that address grave social issues encountered by billions of people, such as limited access to education, environmental pollution, food insecurity, and extreme poverty. Funding from Echoing Green consisted of a two-year stipend of $\$ 90,000$ to two-person partnerships in 2018 . Over the past three decades, Echoing Green has provided more than $\$ 40$ million in seed capital to more than 700 social ventures, as well as mentorship and strategic foundational support from the international business community to help social entrepreneurs achieve their business plan goals.

VPFs select social ventures that have a vision, talent, and strategic plan to maximize social benefits. In contrast to traditional charities, the grant-making process of VPFs is strategic rather than need-based. VPFs seek accountable social entrepreneurs who can generate substantial and tangible social returns with a well-defined goal of creating impact. Thus, to obtain support from VPFs, early-stage social ventures should effectively signal their credibility and capability to achieve the intended social mission. Although social entrepreneurship is attracting growing amounts of talents, grants, and attention today, relatively less scholarly focus has been placed on the signals early-stage social ventures use to successfully raise funding from VPFs and how these signals are formed in the founding phase. To extend our understanding of this topic, the current 
research investigates the following research questions: 1) What characteristics of nascent social ventures contribute to successful fundraising from VPFs? 2) How are these characteristics created during the social venture formation?

In prior research on financing of traditional ventures, signaling theory has been widely applied (Connelly, Certo, Ireland, \& Reutzel, 2011), and the literature showed that information available to investors plays a significant role in the investment decision (Daily, Certo, \& Dalton, 2005). For instance, the knowledge and skills that founders have amassed through past experiences (Dencker, Gruber, \& Shah, 2009; Hsu, 2007) and the features of the founding team (Beckman \& Burton, \& O’Reilly, 2007; Eisenhardt \& Schoohoven, 1990) and those of the venture (Moss, Newbaun, \& Meyskens, 2015) work as crucial inputs that affect resource providers' funding decisions. Along the same line, founder backgrounds and venture characteristics may work as important sources of signals for VPFs' assessment of social ventures.

The entrepreneurship literature has suggested that heterogeneity in talent and expertise within a founding team has a critical impact on the success of a new venture (Bamford, Dean, \& McDougall, 2000). The task-related diversity of the founding team leads to constructive conflicts among team members with different perspectives, which enable them to yield innovative solutions (Der Foo, Wong, \& Ong, 2005; Beckman et al., 2007). Furthermore, the breadth of functional knowledge of a core founder and a founding team can signal social ventures' capability to address entrepreneurial challenges. Thus, I propose that experienced task diversity at both core founder and founding team would positively affect the evaluation of social ventures by VPFs. Additionally, I posit that entrepreneurial orientation (EO) and mission alignment may 
signal a social venture's ability to accomplish a social mission in a creative and efficient manner.

In addition to signals directly affecting funding decisions of VPFs, the current research focuses on how a core founder's breadth of knowledge and personal experience caused by a social problem shape the characteristics of the founding team and the venture. Based upon a resource dependence logic, I theorize that core founders with broad functional experiences would primarily consider candidates' value congruency rather than human capital needs in their new founding team member selection. As core founders with broad sets of functional knowledge are able to fill in many different functions by themselves, they will be more interested in the value of candidates as social entrepreneurs and team players. On the other hand, core founders with fewer functional skills might mainly value the knowledge and the expertise of candidates. This tendency in founding team building becomes more salient when a core founder's motivation for establishing a social venture is related to his or her personal experience with a focal social problem. Having a personal experience implies that a core founder knows why the social mission should be addressed and what needs to be done to support beneficiaries. This in-depth understanding of a focal social problem enhances a core founder's confidence in mission success and thus affects his or her team member selection criteria.

This research offers several contributions. First, it extends our understanding of signaling theory to early-stage social ventures' fundraising context. By highlighting important social venture characteristics that convey positive signals to VPFs, this study elucidates how to effectively reduce information asymmetry between early-stage social ventures and VPFs. Second, the theoretical framework suggested in this study can 
improve our understanding of the spillover effect of core founder characteristics on the social venture attributes. Beginning with a core founder's founding team formation, the proposed model describes how characteristics of a core founder, a founding team, and a social venture relate to each other. Third, this study contributes to social entrepreneurship literature by identifying core founders' personal experiences related to a focal social problem as important resources that affect social venture characteristics.

\section{VENTURE PHILANTHROPY-ORIENTED FOUNDATIONS}

Becoming a fellow of a prominent VPF lends credence to a social entrepreneur's capabilities and enhances their social capital (Sen, 2007). Consequently, receiving funding from VPFs significantly reduces the uncertainty regarding the social entrepreneur's competency (Bugg-Levine, Kogut, \& Kulatilaka, 2012) to other resource providers, thus allowing him or her to access additional funding sources. Diversifying sources of financing enhances the ventures' likelihood of survival. For instance, Meyskens and her colleagues' study of 70 Ashoka fellows demonstrate that, as a source of financing becomes more diversified, the number of partners and the probability of survival significantly increase (Meyskens, Robb-Post, Stamp, Carsrud, \& Reynolds, 2010). Additionally, an evaluation study conducted by Ashoka in 2002 of fellows elected in 1997 revealed that five years after receiving funding from Ashoka, 94\% were still enhancing and spreading their innovations; $93 \%$ had proved their project and, in turn, had been replicated by other independent organizations. An additional 56\% had affected changes in national policies or legislation; and $72 \%$ were considered leaders in their areas (from Sen, 2007). Moreover, 70\% of Echoing Green-funded organizations from 1990- 
2015 are still in operation in 2018. Overall, data shows that successful fundraising from VPFs enhances early-stage social ventures' odds of survival.

Resource providers to early-stage ventures typically examine aspects of the venture, the founder, and the perception of the founder's aptitude for execution (Huang \& Pearce, 2015; Huang \& Knight, 2017; Lee \& Huang, 2018). It implies that resource providers consider the qualities not only of the venture and the founder but also of the fit between the two (Kaplan, Sensoy, \& Stromberg, 2009; Lee \& Huang, 2018). In the evaluation of early-stage social ventures, VPFs face a lack of objective data on ventures' potential success, such as proven products and financial performance, because there is not much available public information about organizations in the early stage (Moss et al., 2015). Furthermore, the quality of social mission is difficult to evaluate. There are no standardized criteria for evaluating the quality of a social mission because all social ventures are driven by virtuous motivation and empathy towards people in need. Therefore, VPFs must heavily rely upon signals based on the attributes of the core founder, the founding team, and the venture that are regarded as co-varying with the social ventures' underlying quality.

For instance, the Echoing Green foundation's application criteria includes purpose/passion, resilience, leadership, and ability to attract resources (Fellowship Program Application Selection Criteria, Echoing Green, 2018). All of these criteria are related to knowledge and previous experiences of a core founder and a founding team. Purpose/passion indicates how deeply an applicant cares and understands about the social phenomenon, which is related to the applicant's personal experience. Leadership indicates unique skills, experiences, and achievements of an applicant. Ability to attract 
resources is also related to an applicant's attributes, including social network, occupational prestige, and educational affiliation.

\section{SIGNALS ACROSS THREE LEVELS: CORE FOUNDER, FOUNDING TEAM, AND VENTURE}

\section{Information Asymmetry and Signaling Theory}

Signaling theory is primarily concerned with information asymmetry between two parties (Connelly et al., 2011; Spence, 2002). As certain information is private, information asymmetry emerges between those who hold private information and those who could potentially make better decisions if they had that information (Connelly et al., 2011). Two types of private information are particularly crucial when information asymmetry exists: (1) information about characteristics such as quality and reliability, and (2) information about the intention of behaviors (Stiglitz, 2000). Signals can be used to help parties resolve information asymmetry related to this unobservable private information (Elitzur \& Gavious, 2003; Moss et al., 2015).

Not all conveyances from social entrepreneurs are deemed valid signals by potential investors. Typically, to be productive, signals must be observable and costly (Moss et al., 2015). Observability indicates the extent to which outsiders can notice the signals. Costly refers to the sender's expense associated with signaling desirable characteristics, such as quality, reliability, and passion. Educational degrees, industry certifications, or professional credentials are examples of observable and costly signals.

Building on this, this research argues that the social venture's likelihood of obtaining funding from VPFs is significantly affected by human capital endowments in founders, which are observable and costly to obtain. Specifically, I focus on the human 
capital of a core founder, an individual who had the initial idea and originated the founding activities (Wasserman, 2012; 2016), and of a founding team. VPFs are likely to focus on the background of a core founder in their venture selection process, because a core founder's characteristics have a significant influence on a social venture' survival rate and performance in future. By attracting co-founders, employees, and investors to enhance organizational capabilities (Wasserman, 2016), core founders initially create fundamental elements for social ventures and pave the path for the ventures' future success. In the following section, the signaling role of a core founder's breadth of functional knowledge and a founding team's dominant function diversity in the VPFs' evaluation will be discussed.

\section{Core Founders' Breadth of Knowledge, Founding Teams' Functional Diversity, and Funding from Venture Philanthropy-oriented Foundations}

The core founder's breadth of functional knowledge. The breadth of functional knowledge of the entrepreneur indicates the extent to which the entrepreneur possesses knowledge of a variety of different business areas necessary for starting and operating a new organization (Denker et al., 2009). It is derived from diverse functional experiences in previous organizations (Taylor \& Greve, 2006). The jack-of-all-trades view of entrepreneurship (Lazear, 2004) posits that experiences in a large number of different roles increase the likelihood of becoming an entrepreneur (Lazear, 2004; Wagner, 2006). This implies that entrepreneurs need to have knowledge in a variety of areas to integrate many ingredients needed for survival and success of business (Wagner, 2006). This integration allows entrepreneurs to take multiple perspectives for deepening the understanding of the business environment. 
The importance of founders' prior experience for identifying problems and creating solutions have been highlighted prominently in the extant entrepreneurship literature. Founders' identification of strategic choices regarding new markets and innovative solutions is significantly bounded by their limited prior knowledge (Fern, Cardinal, \& O'Neill, 2012; Gruber, 2010; Shane, 1995; Shane \& Venkatraman, 2000). Consequently, the search for alternative solutions is less challenging to founders with a broader set of knowledge and experience endowments than people with more constrained endowments, as the former's local search space may be wider and thus more likely to identify diverse alternatives than the latter with a bounded search space (Gruber, 2010). Likewise, founders with a broader set of knowledge and experience are better able to recombine different knowledge components to achieve novel solutions (Gruber, 2010; Taylor \& Greve, 2006). Therefore, business ideas from founders with task-related diversity tend to be positively evaluated by external funders (Der Foo et al., 2005). Building on this, I argue that a core founder who can utilize an extensive set of knowledge and experience endowments may be in a better position to attract funding from prospective investors due to their superior possibilities of arriving at innovative solutions.

Proposition 1: The core founder's breadth of functional knowledge is positively related to the social venture's likelihood of obtaining funding from venture philanthropy-oriented foundations (VPFs).

Founding teams' dominant function diversity. In addition to core founders' breath of functional knowledge, founding teams' diverse knowledge and skills would also 
signal the venture's innovativeness to VPFs. This study focuses on dominant function diversity, which is mainly concerned with a team's breadth of experience across functional categories (Bunderson \& Sutcliffe, 2002). The founding team's dominant function diversity refers to a form of diversity in the different functional areas within which team members have spent the greater part of their careers (Bunderson \& Sutcliffe, 2002). This concept is based on the assumption that each member provides a specific functional perspective to a team, a perspective obtained from experience that is related to a particular function (Bunderson \& Sutcliffe, 2002). Dominant function diversity is high when team members have specialized functional experiences that complement one another in a manner that includes a wide range of functional areas within a team. Comprehensive experiences and perspectives can yield more alternatives to solve complicated problems and lead to a thorough evaluation of alternatives, thus ultimately improving the overall qualities and effectiveness of decisions made by team members (Beckman et al., 2007; Cannella, Park, \& Lee, 2008). Therefore, dominant function diversity engenders positive outcomes for organizations in general (e.g., Cummings, 2004; Wegge, Roth, Neubach, Schmidt, \& Kanfer, 2008).

There is a large stream of entrepreneurship literature relating founding team diversity and its innovativeness (Beckman et al., 2007; Beckman \& Burton, 2008; Chowdhury, 2005; Eesley, Hsu, \& Roberts, 2014; Horwitz \& Horwitz, 2007). For instance, Eisenhardt and Schoonhoven (1990) found that the greater the team heterogeneity is, the higher the growth rate of the new technology firm, because the heterogeneity in industry experience among the members tends to create constructive conflict, which yields innovative outcomes (Eisenhardt \& Schoohoven, 1990). Similarly, 
Beckman, Burton, and O'Reilly (2007) showed that having founding top-management team members with diverse prior experiences yields positive outcomes. Specifically, teams with diverse prior company affiliations and broad prior functional experiences are more likely to achieve critical entrepreneurial firm milestones such as venture capital financing and successful completion of an initial public offering (IPO) than their counterparts with less functional diversity and experiences. As founding teams with a variety of skills and experiences tend to yield more innovative performances by integrating diverse perspectives, their ventures are likely to obtain much attention from investors (Beckman et al., 2007).

VPFs importantly consider the innovativeness of social ventures in their venture selection process (Short, Moss, \& Lumpkin, 2009). As social ventures are established to address social problems that are not solved by governmental help and an extant firm's approach, their solutions need to be creative to result in meaningful social changes. Furthermore, early-stage social ventures need to deal with a series of unexpected situations. A wide range of expertise and knowledge within founding teams can improve the quality of ventures' decisions in complex situations. Therefore, a founding team's dominant function diversity conveys a positive signal to VPFs.

\author{
Proposition 2: The founding team's dominant function diversity is \\ positively related to the social venture's likelihood of obtaining funding \\ from venture philanthropy-oriented foundations (VPFs).
}


In addition to human capital attributes of a core founder and a founding team, characteristics of a venture deliver important signals to prospective resource providers. In the following section, I suggest that social ventures' entrepreneurial orientation (EO) and mission alignment enhance the possibility of obtaining funding from VPFs.

\section{Social Ventures' Entrepreneurial Orientation (EO) and Mission Alignment on Funding from Venture Philanthropy-oriented Foundations}

Entrepreneurial orientation. Social entrepreneurship has been broadly conceptualized as reflecting two key elements: an overarching social mission and entrepreneurial creativity (Nicholls, 2006; Peredo \& McLean, 2006). Dees (1998) declared, "social entrepreneurs are one species in the genus entrepreneur" (p. 3). Based on Drucker (1985) and Stevenson, Roberts, and Grousbeck (1989), Dees (1998) identified the entrepreneurial aspects of social entrepreneurship as recognizing opportunities, continuously engaging in innovation and modification, and displaying resourcefulness, which means the refusal to be constrained by prevailing resource limitations. Highlighting the entrepreneurial element in social entrepreneurship, Pomerantz (2003) describes key aspects of a social venture involve taking a businesslike, innovative approach to the mission of delivering community services (Peredo \& McLean, 2006). Overall, scholars emphasized that innovation is an essential component of social entrepreneurship (Short et al., 2009).

Since social entrepreneurship emerges because of an unfulfilled need by traditional organizations, the replication of existing practices and processes is inadequate for social ventures to address social issues (Austin, Stevenson, \& Wei-Skillern, 2006). Accordingly, EO, which represents a mindset and framework regarding entrepreneurship 
that is reflected in a firm's ongoing strategy-making processes, structures, and behaviors, may signal that the social venture is sufficiently capable to resolve a focal social problem in an innovative manner (Lyon, Lumpkin, \& Dess, 2000). Miller (1983) posited innovativeness, proactiveness, and risk-taking as constituents of EO and these were combined to form a higher-order indicator at the firm-level. Lumpkin and Dess (1996) conceived two additional constituents — competitive aggressiveness and autonomy—to the original three domains of EO (Rauch, Wiklund, \& Frese, 2017; Saha, Kumar, Dutta, \& Dutta, 2017).

Research in entrepreneurship has noted that the $\mathrm{EO}$ of a venture is a crucial determinant of the venture's positive outcomes related to both financial and non-financial performance (Wilkund \& Shepherd, 2005; Zahra, Nielsen, \& Bogner, 1999). EO also plays a significant role in the non-profit organizations' growth and sustainability and facilitates the market orientation of the non-profit (Morris et al., 2007). The role of EO is particularly salient when the ventures are under conditions of environmental turbulence (Morris et al., 2007). Therefore, the role of EO would be salient in the context of earlystage social ventures as well.

VPFs have stated that social ventures' entrepreneurial skills and creativity are important selection criteria. The previous research provides evidences that social venture capitalists tend to relate a social venture's innovative capabilities to its probability of being effective (Miller, Wesley, \& Curtis, 2010). An empirical study lends weight to this finding by showing that impact investors primarily attribute eco-ventures' failure in fundraising to the lack of innovativeness (Randjelovic, O'Rourke, \& Orsato, 2003). 
Considering these points, I suggest that the $\mathrm{EO}$ of social ventures will enhance the likelihood of winning funding from foundations over their counterparts with lower EO.

Proposition 3: The social venture's EO (entrepreneurial orientation) is positively related to the social venture's likelihood of obtaining funding from venture philanthropy-oriented foundations (VPFs).

Mission alignment. The social mission is the raison d'être of social ventures. An organizational mission embodies the most fundamental signal of an organization's identity and its ultimate goal (Bart, Bontis, \& Taggar, 2001; Perrini \& Vurro, 2006). Dees (1998) posits that the dedication to the mission of creating and sustaining social impact is what distinguishes organizations in social entrepreneurship from those in the commercial and traditional entrepreneurship sector. In its fellow selection process, Echoing Green foundation crucially considers the importance of social issue that an applicant addresses, an applicant's potential for creating big, bold impact, and an effectiveness of business model. To signal its effectiveness to VPFs, social entrepreneurs need to be clear and concise in how their social venture will run. In other words, all organizational elements of social ventures need to be aligned to support its social mission to successfully raise seed capital from VPFs.

Organizational alignment refers to the degree to which an organization's design, strategy, and culture are cooperating to achieve the same desired goals (Semler, 1997). High alignment requires agreement rather than conflict among the strategic, structural, and cultural variables. Nearly by definition, an organization that is well aligned is 
efficient. Tichy (1983) posited that the strategic management task is to maintain an organization that is both internally and externally aligned. Miles and Snow (1984) extended this reasoning by suggesting that an organization that has a tight fit or alignment with various contingency factors (e.g., size, environment, technology, resource availability) can significantly improve firm performance (Crotts, Dickson, \& Ford, 2005). The researchers also stated, "Tight fit is the underlying causal dynamic producing sustained, excellent performance and strong corporate culture” (Miles \& Snow, 1984).

As a type of internal organizational alignment, mission alignment indicates a consistent fit between the organizational mission and the structure, policies, and procedures of the organization and the practices of its leadership (Crotts et al., 2005). A strong mission alignment offers the organization the ability to focus its resources on the desired outputs with the greatest efficiency. A strong congruency between social mission and other organizational elements, such as organizational structures, practices, and procedures, implies social ventures' effectiveness in the strategic positioning and the decision-making pattern for creating meaningful social impacts. As VPFs want to select early-stage social ventures that lead to appropriate and noticeable social changes, social ventures with a strong mission alignment may convey a favorable signal to VPFs.

Proposition 4: The venture's mission alignment is positively related to the social venture's likelihood of obtaining funding from venture philanthropy-oriented foundations (VPFs). 


\section{THE FORMATION OF SOURCES OF SIGNALS ACROSS THREE LEVELS The Importance of Core Founders' Initial Decisions}

The creation of a new organization entails myriad decisions. Initial decisions are the charge of a core founder, who has the idea to launch the startup and is driving the initial stage of establishing it. In many cases, core founders initiate entrepreneurial activities entirely on their own, although later in the process they may turn to others for help. Others begin with a team, forming an organization with collective efforts. Once a core founder decides to make a founding team, he or she invites co-founders. These initial strategic choices of a core founder are crucial for the venture's future because these choices have lasting consequences for the venture's survival and performance (Ruef, Aldrich, \& Carter, 2003).

The founding period remains the key sensitive period for organizations, as it marks the fundamental transition from nonexistence to existence (Marquis \& Tilcsik, 2013). The social imprinting literature noted that the elements an organization takes from its founding environment will persist well beyond the founding phase (Johnson, 2007; Marquis \& Tilcsik, 2013). Founders leave legacies in ventures by making crucial decisions early on in the venture's development (Mathias, Williams, \& Smith, 2015). Baron and his colleagues (1999) found that a founder's initial decisions concerning human resources during the early stage of the firm constrain the pool of people who may be willing or able to join the company, thus have an enduring effect on the firm's employment pattern (Barron, Hannan, \& Burton, 1999). Similarly, Johnson (2007) emphasized the important role of entrepreneurs "who stamp new organizations with the distinctive signs of their founding times" (Johnson, 2007, p. 122). Namely, organizations 
select and incorporate elements of the historically specific environment through its founders (Johnson, 2007; Marquis \& Tilcsik, 2013). Overall, the research highlights the major role of founders in choosing and integrating contextual factors into ventures, which become lasting parts of ventures.

The prior work on new ventures has shown that a founders' prior work experiences shape a firm's initial strategy in founding team formation (Denker et al., 2009; Fern, Cardinal, \& O'Neill, 2012; Kim \& Longest, 2014). For instance, Fern, Cardinal, and O'Neill (2012) found that a founder's experience strongly constrains choices of new companies. Similarly, Kim and Longest (2014) demonstrated various aspects of occupational experiences of a founder that affect the number of people founders choose to involve in founding efforts. While founders with highly interactive occupational backgrounds are more likely to opt for more collaboration, founders possessing venture-specific industry experience are more likely to recruit a small number of collaborators or start solo. Additionally, an entrepreneur possessing a greater breadth of knowledge tends to create fewer jobs, and entrepreneurs possessing prior leadership experience tend to create more jobs (Denker et al., 2009). Generally, the previous literature acknowledges that the founder's human capital characteristics, including preentry knowledge endowments and breadth of knowledge, are key to determine the venture's early strategy for adding new members.

\section{Core Founders' Breath of Functional Knowledge and Founding Team Formation}

Some scholars view the addition of a new member as driven by economic, instrumental considerations, while other scholars view the process as motivated primarily by interpersonal attraction and by social networks (Forbes, Borchert, Zellmer-Bruhn, \& 
Sapienza, 2006). According to the first view, new members are selected based on the firm's needs to fill particular "gaps" in capabilities. Several early conceptual studies elaborate this competency-driven search perspective of team formation (Francis \& Sandberg, 2000; Larson \& Starr, 1993). A resource-dependence view is implicit in the competency-driven search model; the process is intentionally rational and focuses on identifying the candidate with the best access to resources critical to moving the firm forward (Forbes et al., 2006). Reflecting the resource dependence view, a study by Ucbasaran and his colleagues (2003) showed that the size of the founding team is negatively related to the addition of new members to the founding team. This finding indicates that seeking new members is often driven by a deficiency in the necessary functions (Ucbasaran, Lockett, Wright, \& Westhead, 2003).

The second view for founding team expansion is based on the literature of the social psychological needs of existing team members. Ruef and his colleagues (2003) found that the entrepreneurial team composition was strongly influenced by relational trust and the homophily of personal characteristics. In the sociology literature, homophily refers to the selection of other team members by similar characteristics, such as gender, ethnicity, nationality, appearance, and more (McPherson, Smith-Lovin, \& Cook, 2001; Ruef et al., 2003). Sociologists have shown in small businesses that people of the same gender or race and people of similar geographic origins, educational backgrounds, and functional experiences are disproportionately likely to establish companies together (Wasserman, 2012).

In the founding team context, homogeneity has substantial benefits, likely the most immediate of which is speed. For a founder who was scrambling to meet the 
challenges of a growing startup, choosing co-founders between people who he or she currently knows may be the quickest and easiest solution. This process also generally takes less time to develop effective working relationships with people who are similar to the core founder. When founders share a similar background, they share a common language, culture, and narratives that facilitate communication. For instance, Francis and Sandberg (2000) found that friendship allows the venture to incorporate people who would otherwise price their services beyond the reach of a startup venture if friendship were not involved (Forbes et al., 2006; Francis \& Sandberg, 2000). Thus, when a core founder can use social networks to add new members, the search may be affected by similarities between a core founder and a prospective member, previous relationships, and shared networks, instead of a prospective member's functional expertise.

As all entrepreneurial decisions involve complexity, responsibility, and challenges, founders with the breadth of functional knowledge should be able to address these difficulties more proficiently than founders with the less diverse knowledge set (Burke, Fitzroy, \& Nolan, 2000). In addition, due to the broad skill sets and diverse industry knowledge, founders with broad functional knowledge are liable to believe that their capabilities are currently sufficient to realize business ideas. Having such confidence lowers the perceived needs for immediate assistance and reduces the motivation for seeking collaborators with complementary knowledge (Kim \& Longest, 2014; Toft-Kehler, Wennberg, \& Kim, 2014). Thus, these entrepreneurs are less likely to recruit strangers in need of functional assistance early on (Kim \& Longest, 2014). Therefore, I propose that, when a core founder has experience in diverse functional areas, the level of the founding team's dominant function diversity may decrease. 
Proposition 5: The core founder's breadth of functional knowledge is negatively related to the founding team's dominant function diversity.

The team building process of homophily suggests that, when free choice is possible, individuals will interact with others in a like-minded manner (Burt \& Reagans, 1997; Forbes et al., 2006). According to homophily logics, when a core founder possesses substantial knowledge sets necessary for moving the social venture forward and has a network that enables him or her to access a large pool of human resources, the core founder is likely to add new members based on interpersonal attraction or similarity in mindsets instead of complementary resources.

Previous research suggests that social networks provide inexpensive and trustful sources of information about necessary resources for entrepreneurs (Forbes et al., 2006), and they are the most common sources for seeking business partners (Ensley, Carland, Carland, \& Banks, 1999). Core founders with broad functional knowledge are likely to have a larger social network than their counterparts who have been working at one functional position. This opens the possibility for these core founders to invite people from previous employment to new founding teams because it significantly reduces the uncertainty of new member invitation.

New founding team members who joined from a core founder's social network may possess a similar mindset and identity with a core founder because new members decide to endure a high degree of uncertainty by joining the social venture and working 
with the core founder. Joining a new social venture is a financially risky decision, as its founding is primarily driven by a strong orientation towards a social change and empathy towards people in need instead of by economic self-interest. Furthermore, the structure of a social venture is more unstable than traditional organizations in general. Unless new members agree with the social mission of the venture, they may not take such a high risk at the expense of their current job.

Overall, founders with a breadth of occupational knowledge for launching a social venture are more likely to invite founding team members on a familiarity and attraction base instead of a functionality base. Thus, expectedly, the founding team constructed by a core founder with a breadth of functional knowledge will incorporate people who possess a similar mindset, agree on a social venture's mission and vision and have a strong bond with a core founder. This founding team will have a high level of shared team identity. Accordingly, new founding team members selected throughout network searching may possess similar values to the core founder.

Proposition 6: The core founder's breadth of functional knowledge is positively related to the founding team's shared team identity.

\section{The Moderating Role of Core Founders' Direct Personal Experience with a Focal Social Problem}

Each social entrepreneur has a different motivation of starting a social venture. The motivation of some social entrepreneur is based on triggering events that afford 
reasons to help others or to address social problems. Due to the variance in sources of motivation to establish a social venture, each social entrepreneur possess a different level of understanding of the focal social problem, the beneficiary groups, and of the institutional structure of the context that their organization operates in. At the one extreme, there are entrepreneurs who had directly suffered from the focal social problem at one point in life. For example, the founding motivation of Matt Dickson, a social entrepreneur who strives to empower young women in Kenya to launch their egg farming businesses, lies in his childhood experience (Echoing Green, 2016). Born and raised in Kenya, he acknowledges the realities of poverty. His understanding and experiences of poverty inspire him to create a social venture that can provide better and healthier life for his family and community. Conversely, the other extreme may be social entrepreneurs who have limited exposed to the focal social problem, such as people who recognize the opportunity for social business by a coincidence. A variety of different cases can exist in between.

Previous research suggests that social entrepreneurship is more problem-solving focused than traditional ventures, thus how a social entrepreneur is related to the focal social problem can largely explain the social ventures' entrepreneurial process and performance (Yitshaki \& Kropp, 2016). For instance, if a social entrepreneur had gone through the focal social problem in past, he or she is likely to have a concrete understanding about the phenomenon and detailed contextual information surrounding the issue. This personal experience with the social problem provides the social entrepreneur with specific and unique knowledge set about the problem that the social ventures addresses which might ease the venture's effective operation. Thus, an 
entrepreneur's personal experience with the social problem is a valuable resource. It is also rare and non-imitable, as it is primarily accrued from an entrepreneur's life events.

The accrued knowledge from an experience with a social problem is fundamentally different from the knowledge obtained from social functional occupational experiences. Unlike functional knowledge, direct personal experience with the social problem is not easily tradable or applicable outside of the social venture. Therefore, it could only serve as a source of sustainable competitive advance in the social entrepreneurship context. In summary, under the circumstances of social entrepreneurship, as a valuable, rare, and non-imitable resource, direct personal experience with the social problem provides social entrepreneurs with a much clear understanding of why the focal social issue should be solved, what is necessary for mitigating it, and what needs to be done for effective implementation of strategy.

When social entrepreneurs with the breadth of knowledge also have personal experiences that drive them to solve the focal social problem, they may believe that they have sufficient capabilities to build and operate new ventures. Being confident lowers the perceived need for immediate assistance and reduces the motivation of seeking collaborators (Kim \& Longest, 2014; Toft-Kehler, Wennberg, \& Kim, 2014). Thus, personal experience may enhance the tendency of founders with the breadth of knowledge to avoid the pursuit of a functionally diverse founding team. Therefore, I suggest that the manner in which a core founder experiences a focal social problem may attenuate the influence of the core founder's breadth of knowledge on the pattern of composing a founding team. 
Conversely, although a core founder has a wide range of functional experiences, without direct personal experience with a focal social problem, the core founder may be inclined to compose a more "complete" founding team. To complement the deficiency in in-depth understanding about the focal social problem, these core founders are likely to invite individuals who are experts in various areas. This practice will strengthen the dominant function diversity of a new social venture. Given the arguments thus far, I suggest that the founder's manner of experiencing social problems and their range of functional knowledge will jointly determine the dominant function diversity level of a founding team.

Proposition 7a: The core founder's personal direct experience with the social problem positively moderates the negative link between the core founder's breadth of functional knowledge and the founding team's dominant functional diversity.

Having worked in various areas provides greater confidence to social entrepreneurs in addressing challenges relevant to the founding of a social venture as well as its operation. Additionally, this experience provides social entrepreneurs rich social networks in addition to diverse knowledge and skills. Thus, social entrepreneurs with diverse pre-entry occupational experiences tend to convince others that they are sufficiently capable to attain the necessary resources in time from outside of the firm's boundary. This tendency will be further augmented by social entrepreneurs' belief that they have a thorough understanding of the context that the social venture will operate in 
for managing unexpected challenges. In this circumstance, the search for founding team members is likely to be more relational instead of functional. Furthermore, core founders who lack contextual knowledge and direct experience with the social problem are more willing to seek assistance from other collaborators who can provide useful resources for the social venture. Thus, I expect that core founders without direct experience with the focal social problem are more likely to expand the search for founding team members with the necessary expertise beyond their own social network. As a result, the shared team identity of the founding team may decrease.

Proposition 7b: The core founder's personal direct experience with the social problem positively moderates the positive link between the core founder's breadth of functional knowledge and the founding team's shared team identity.

\section{The Influence of Founding Teams' Dominant Function Diversity on Social Ventures' Entrepreneurial Orientation (EO) and Mission Alignment}

\section{Founding teams' dominant function diversity and social ventures' EO and}

mission alignment. For young startups, having top management team members who have diverse prior experiences and myriad prior company affiliations yield positive venture outcomes (Bamford et al., 2000; Beckman et al., 2007). Moreover, the taskrelated diversity of founding team members enhances team effectiveness and thus positively affects the external evaluations of the team's business idea (Der Foo et al., 2005). Beckman (2006) noted that founding teams whose members have worked at 
diverse organizations are likely to engage in explorative behaviors because they have access to various information, ideas, and alternatives. Overall, the extant diversity literature suggests that different backgrounds and expertise within the founding team enhances the venture's level of creativity (Woodman, Sawyer, \& Griffin, 1993).

Creativity requires the capacity to think divergently, view things from various perspectives, and combine separate processes and products in novel modes (Amabile, 1996; Shin, Kim, Lee, \& Bian, 2012). The value of diversity resides in the increased range of knowledge, skills, and perspectives available within a team (Williams \& O'Reilly, 1998), which can be sources of creativity and innovation (Shin et al., 2012). Related to the extant literature, I propose that the dominant function diversity of founding team members may heighten their social ventures' level of entrepreneurial orientation, which represents the entrepreneurial mindsets and behavioral patterns of the venture.

\section{Proposition 8: The founding team's dominant function diversity is} positively related to the social venture's EO (entrepreneurial orientation).

Conversely, the prior literature reveals that team functional diversity does not always have positive effects on venture performance (Bettenhausen, 1991; Kanter, 1988; Lovelace, Shapiro, \& Weingart, 2001). Excessive diversity can make it difficult for team members to flesh out a given perspective in any depth, perhaps because issues compete for attention when team members are diverse (Dahlin, Weingart, \& Hinds, 2005). The new product team research found that the greater conflict in heterogeneous rather than homogeneous groups is often due to the difficulty that people have in understanding each 
other when the members have different languages and vocabularies because of their professional socialization experiences and different goals (Dougherty, 1992). Empirical evidence suggests that the more functionally diverse a team is, the more extensive their task disagreements are (Lovelace et al. 2001). Given these points, I suggest that a founding team's dominant function diversity may exacerbate the social venture's mission alignment, which reflects the founding team members' level of agreement on the mission and the strategic direction of social ventures.

Proposition 9: The founding team's dominant function diversity is negatively related to the social venture's mission alignment.

\section{Founding teams' shared team identity and social ventures' EO and mission}

alignment. A shared identity among founding team members is one of the key entrepreneurial resources for new ventures with limited financial and human capital (Beckman, 2006; Hinds \& Mortensen, 2005). A strong shared identity can reduce the level of interpersonal conflicts (Jehn, Northcraft, \& Neale, 1999). Social categorization theory suggests that individuals reduce ambiguity and promote self-enhancement by partitioning their colleagues by relative similarity to themselves. Individuals create "ingroups" composed of similar others and "out-groups" of those who are perceived as being different (Tajfel, 1974; 1981). The intergroup hostility can surface as conflict over workgroup members' personal preferences or disagreements about interpersonal interactions, typically about non-work issues such as gossip, social events, or religious preferences. Therefore, team members with a strong shared identity are less likely to 
experience relationship conflicts that lead to massive inefficiency in strategic decision making and implementations.

The founding environment of an early-stage social venture is highly uncertain. Under such context, founding team's shared identity can be a valuable asset, as it allows founding team members to communicate more efficiently than their counterparts who do not have strong shared team identity (Smith, Smith, Olian, Sims Jr, O’Bannon, \& Scully, 1994). Extant literature provides empirical evidence that founding teams with familiar members perform better because of improved coordination, high team cohesion, and enhanced intra-team trust (Kor, 2003; Zheng, 2012). Additionally, intra-team trust improves coordination among team members since its development of social or working interactions reduces emotional conflicts among team members (Edmondson, 1999; McEvily, Perrone, \& Zaheer, 2003; Zheng, 2012). Therefore, when the founding team has a strong shared identity, the new social venture is likely to exhibit strong mission alignment, because all founding team members may easily achieve an agreement on new ventures' direction and other strategic decisions relevant to mission achievement.

Proposition 10: The founding team's shared team identity is positively related to the social venture's mission alignment.

Founding teams with common prior affiliations tend to engage more in exploitative strategies, because they have shared understandings and can thus act quickly. However, founding teams composed of members who have worked at many different 
companies tend to engage more in explorative strategies because they have access to diverse information, unique ideas, and alternatives (Beckman, 2006). Heterogeneity in team resource endowments facilitates innovation-related performance of ventures and thus has a critical impact on the success of the new venture (Bamford et al., 2000). Collectively, extant studies posit that team composition shapes the range of new ventures' outcomes relevant to innovation.

"Groupthink" encourages individuals working closely together to think in the same way about issues (Shane, 1995). Groupthink often leads to concurrence-seeking tendencies and a failure to realistically evaluate different alternatives (Nijstad \& De Dreu, 2002). To smooth over conflicts and maintain high cohesion, team members with a high level of cohesion are likely to reject opposite views and only accept convergent opinions. The convergent thinking style and a confirmatory manner to appraise information are unlikely to cause creative solutions and high levels of innovation. Thus, the tendency of conformity prevalent in a team can restrict group innovativeness and cause only mediocre-level innovation (Chen, Liu, \& Tjosvold, 2005).

Shared team identity generates intra-team trust and team integration; however, excessive group cohesion often sacrifices each person's unique idea to settle for mundane solutions that are agreeable to all team members (Barton Rabe, 2006). Therefore, I suggest that, when the founding team has a strong shared identity, they are likely to demonstrate a lower level of entrepreneurial orientation than their counterparts with a weaker shared identity who often experience constructive conflicts and disagreement on each other's perspective. 
Proposition 11: The founding team's shared team identity is negatively

related to the social venture's entrepreneurial orientation (EO).

\section{Model 1: A Theoretical Model of Early-stage Social Venturs' Fundraising from VPFs}

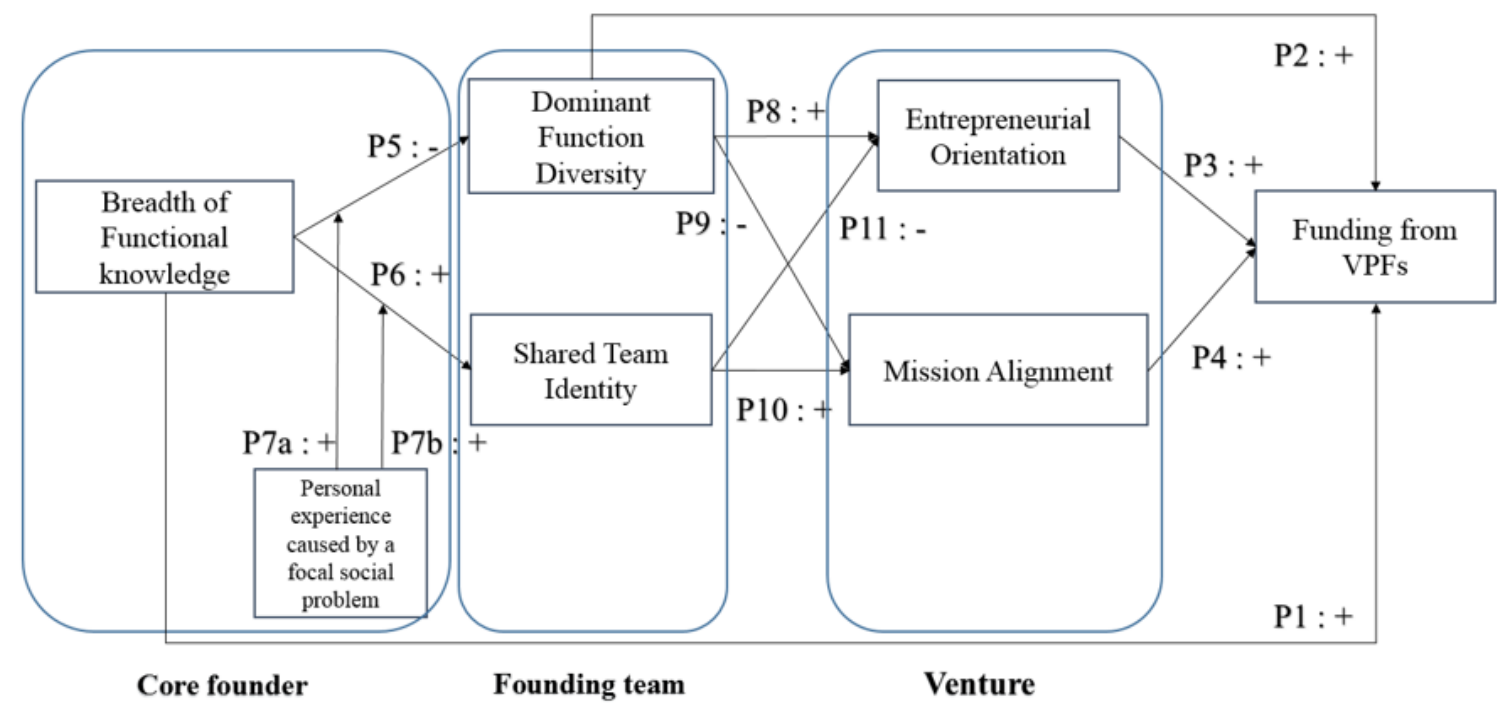

\section{DISCUSSION}

VPFs are increasingly recognized as important supporters for early-stage social ventures. However, our understanding of signals that social ventures can use to attain funding from VPFs and the sources of such signals has been limited. Due to the limited availability of objective data on proven products or financial records, VPFs are more likely to rely on relatively subjective but observable and costly signals related to social ventures' capabilities to achieve their goals. Based upon insights from the signaling theory, I investigated sources of such signals including the breadth of functional knowledge of core founder, the functional diversity of the founding team, and the 
entrepreneurial orientation and mission alignment of the venture, which may extensively affect funding decisions of VPFs.

Additionally, the current research provides a theoretical framework describing the process and development of the sources of signals across three domains: core founders, founding teams, and social ventures. By explicitly utilizing the process of the spillover effect of a core founders' characteristics on his or her team and venture, the suggested theoretical framework contributes beyond the other signaling theory literature that focuses on direct signaling of ventures. Although these theories provide comprehensive explanations on effective signals, they do not offer any explanations on how these signals are shaped and evolved, which is the focal point of the theory of this research.

\section{Theoretical implications}

This research makes several theoretical contributions to the extant literature. By applying signaling theory to demonstrate the fundraising process of early-stage social ventures, this research expands the range of where the signaling process occurs. By focusing on the unique context of social ventures seeking funding from VPFs, the theoretical model provides a holistic picture of which signals are crucial for the earlystage social ventures' fundraising success from VPFs and how they are created. In most theoretical arguments on venture financing, the discussion is often limited to ventures' features laid in a single level. The suggested model describes how variables across three levels, core founder, founding the team, and entity, concurrently contribute to the increasing possibility of funding from foundations. 
Moreover, this study adds value to the entrepreneurship literature by highlighting the importance of having members with a variety of expertise and skills to successfully obtain seed capital from VPFs. Similar to prior studies investigating micro-financing lenders' decision making (Moss et al., 2015), I argued that certain factors imply innovativeness and effectiveness of social ventures; for example, the breadth of knowledge of a core founder, the dominant function diversity of a founding team, the EO, and the mission alignment are much more favorably considered than the social mission in VPFs' assessments of early-stage social ventures. VPFs intend to generate social impact from their investment, which is fundamentally different from venture capitalists (VCs) for traditional ventures whose goal is to maximize financial returns. Despite this major difference, both VPFs and VCs do not want their investment to fail; thus, they may focus on the early-stage organizations most likely to survive and thrive. The theory emphasizes that, for ventures with a social mission, entrepreneurial qualities are essential to obtain support from resource providers.

This research also elucidates the spillover effect of a core founder characteristics on team and venture formation, which ultimately affect the investment decisions of VPFs. The prior literature on early-stage social ventures explains what makes social ventures succeed; however, it does not explicate how social ventures create such factors during its venture formation process. This paper addresses this gap by identifying that a core founder's breadth of knowledge and personal experiences relevant to social venture founding motivation are particularly crucial for shaping other factors in social ventures. Utilizing insights from the research on social imprinting, entrepreneurial team-building, and team diversity, the theory explicates how a core founder's breadth of knowledge and 
personal experience with a focal social problem affect his or her criteria on founding team member selection and eventually shape the level of EO and mission alignment of new social ventures.

Additionally, this research adds value to the social entrepreneurship literature by recognizing that a core founder's personal experience with a focal social problem affects the founding team and venture formation process. This research is the first that considers the triggering events of establishing social ventures as resources that can potentially contribute to the team-building process. The prior scholarly focus has been mainly on exploring social entrepreneurs' various motivations to initiate founding activities to address social problems (Germak \& Robinson, 2014; Yitshaki \& Kropp, 2016). Extending previous research on entrepreneurs' motivation, I examine how variances in founding motivations of social entrepreneurs would affect the team-building process. I believe the current research offers opportunities for future research on social entrepreneurs' motivation to start social ventures. Future research can address how the narrative of the social entrepreneur's founding story affects the resource provider's assessment of the social venture. Additionally, scholars can explore differences in personal experiences with social problems related to social ventures' survival rate and future performance.

\section{Practical implications}

This research has several implications for social entrepreneurs considering VPFs as potential option for fundraising. This paper clarifies positive signals that are effective in attracting finances from VPFs. For social entrepreneurs, a greater awareness of their own characteristics can be critical in obtaining funding from VPFs. Additionally, this 
research emphasizes that entrepreneurial orientation and mission alignment are sources of positive signal of the new ventures' capabilities; thus, emphasizing these features in the application process may enhance the possibility of fundraising success. The diverse expertise and skill sets within a founding team can signal the innovativeness and effectiveness of a social venture.

Moreover, this research helps social entrepreneurs figure out their strengths and weaknesses and consequently build effective social ventures. For instance, a core founder's personal experience with the focal social problem can change his or her pattern of recruiting founding team members, which is directly associated with a venture's characteristics. Understanding this process can offer insights to social entrepreneurs to be better equipped for the recruitment of founding team members as well as the application for funding from VPFs. A core founder with personal experience with the focal social problem can also actively utilize the experience to build the strong shared identity of the founding team. Social ventures with strong shared identity can effectively improve their funding possibilities by focusing on signaling superior mission alignment. On the other hand, social ventures composed of like-minded people can prepare for the potential risk of groupthink, which lowers the ventures' level of entrepreneurial orientation. Conversely, teams with a high level of dominant function diversity can take a systematic approach to enhance their strong entrepreneurial orientation, while contemplating the manner of aligning their social mission with the venture's other components. In accordance with the knowledge and experience within the venture, social entrepreneurs can generate various strategies to pursue finances from VPFs. 


\section{CONCLUSION}

Although VPFs are emerging as important resource providers for early-stage social entrepreneurs, not much scholarly focus has been accorded this topic. Utilizing insights from signaling theory and team diversity literature, the current theoretical model explicates social ventures' factors that deliver positive signals to VPFs and how these positive signals are created in the venture formation process. This research contributes to understanding how early-stage social entrepreneurs and social ventures seek financial resources from VPFs to elicit social changes. Furthermore, this research emphasizes that, when social entrepreneurs understand their characteristics well, they can better generate an effective strategy to obtain the necessary resources from resource providers. I hope this research yields new dialogue and research on early-stage social ventures and VPFs. 


\title{
CHAPTER 3: LEADERSHIP EMERGENCE IN EARLY-STAGE SOCIAL VENTURES: HOW DOES THE FOUNDING TEAM SELECT THE FIRST CEO?
}

\begin{abstract}
This study examines leadership emergence in early-stage social ventures, entrepreneurial organizations aim to solve social problems with business models. The first CEO of the social venture plays a crucial role in paving the way for the new venture's success, yet we know little about how the first CEO is selected by founding team members. Drawing on insights from human capital theory and expectancy violation theory, this study examines the criteria founding teams use when they select one of them as the first CEO of social venture. In particular, the current study focuses on how founders' prior occupational experience and gender influence the CEO selection. Findings indicate that a founder's social experience substantially affects his or her emergence as the CEO. Additionally, commercial experience enhances a founder's likelihood of becoming the CEO only when the founder is a woman. By accounting for leadership emergence in social entrepreneurship context, this study offers important implications for social entrepreneurship research.
\end{abstract}

\section{INTRODUCTION}

Social ventures have a dualistic nature, integrating social welfare and commercial logics at their core (Battilana \& Lee, 2014; Wry \& York, 2017). This dualism makes social ventures distinct from commercial ventures or other organizations that primarily 
focus on shareholders' economic prosperity (Dees, 1998). A social venture is built upon the founding efforts of core founders who first design the innovative idea of resolving a social problem that cannot be eradicated with governmental help or market intervention (Hellmann \& Wasserman, 2017; Wasserman, 2006). At the beginning of a new venture, resources in three major areas (human capital, social capital, and financial capital) are usually in limited supply (Morris, Coombes, Schindehutte, \& Allen, 2007).To attract missing resources, core founders often assemble a founding team, and the team members together create essential elements for the venture and set the path to organizational success.

At social ventures' early stage, founding team members need to select their representative, the first CEO. Leadership emergence literature suggests that when group members select their leader, they naturally engage in a comparison process between the shared image of a prototypical leader and each leader candidate (Neubert \& Taggar, 2004). Founding team members typically select the individual who seems to be a prototypical leader as the $\mathrm{CEO}$ to maximize the chance to fulfill the collective goal. However, we know little about on basis of which criteria social venture founding teams would select their first leader. Which specific leadership qualities are valued in the organization in which both social mission and profit generation matter? Although less is known about the factors that influence the first CEO selection in social ventures, understanding the features of the first CEOs is of importance to entrepreneurship scholars who are interested in decision making of early-stage founding teams. It is also important to impact investors who select and support promising early-stage social ventures, and to social entrepreneurs who might compete for the CEO position in now or future. 
Scholars suggest that founders' task-relevant human capital, which may provide skills specific to a particular job context, has a positive effect on new ventures' performance (Unger, Rauch, Frese, \& Rosenbusch, 2011). In the social entrepreneurship context where both economic and social goals are crucial, human capital associated with either commercial or social welfare logic might be valued. A conceptual research recently coined the concept of "balanced entrepreneur" (Wry \& York, 2017), which indicates a social entrepreneur with salient role identity related to both commercial logic and social welfare logic. These social entrepreneurs have work experiences in commercial firms and social mission-oriented organizations; thus, they possess knowledge, competencies, and social relations related to both commercial and social welfare domains. They tend to spot more opportunities to create social and commercial value, put more efforts into the integration of commercial and social welfare logics, and strive to focus on social and commercial aims without sacrificing their counterparts with either a commercial or social welfare background (Wry \& York, 2017). In addition to human capital associated with either commercial or social sector, the current study investigates how a social entrepreneur's "balanced" background would operate in leadership emergence.

Gender is another important individual characteristic associated with leadership emergence (Eagly \& Karau, 1991; Lanaj \& Hollenbeck, 2015). According to gender role theory (Ridgeway \& Correll, 2004) people tend to believe that men have more agentic qualities that accompany success in business, whereas women have more communal qualities necessary for supporting others. It provides a partial explanation for men's overemergence as leaders in workplace. Applications of this theory show that women who perform agentic behaviors likely experience social backlash and are penalized in the 
workplace (Lanaj \& Hollenbeck, 2015). However, later applications of the theory demonstrate that the context where these behaviors occur matters and agentic behaviors performed by women are not perceived negatively under specific circumstances (Heilman, 2012; Lanaj \& Hollenbeck, 2015). Instead, Expectancy violation theory (Jussim, Coleman, \& Lerch, 1987) predicts that when women engage in positive behaviors that are prototypical leader behaviors but atypical for the gender stereotype, they are likely to be assessed more positively than men who engage in the same behaviors (Lanaj \& Hollenbeck, 2015; Schaumberg \& Flynn, 2017). Lanaj and Hollenbeck (2015) showed that women benefit from a countervailing bias in selfmanaging team by engaging in more task behaviors and boundary spanning behaviors.

Traditionally, male stereotypes are associated with the goals and motivations of the commercial sector, whereas female stereotypes are associated with the goals and motivations of the social sector (Dimitriadis, Lee, Ramarajan, \& Battilana, 2017). In social ventures, however, ideal leaders need to be both agentic and communal because of the organizational need to serve the financial goal and social mission simultaneously. It makes us difficult to predict how gender works in social venture founding team members' evaluation on CEO candidates' leadership quality. In the current study, I propose that expectancy violation theory (Jussim et al., 1987; Lanaj \& Hollenbeck, 2015; Schaumberg \& Flynn, 2017), rather than gender role theory (Eagly \& Karau, 1991) can better account for the role of gender with respect to leadership emergence in social venture context. In a social venture, a team member whose background is not consistent with his or her gender stereotype might be perceived as representing balanced qualities, thus is more likely to become the CEO than other team members with gender stereotype- 
consistent background. Specifically, women with prior commercial experience and men with prior social experience are more likely to emerge as leaders than men with prior commercial experience and women with prior social experience.

By identifying characteristics of the first CEO of social ventures, this study offers a fresh perspective on how human capital and positive gender stereotype violation may affect founding teams' CEO selection. This study makes several theoretical and practical contributions. First, it contributes to the social entrepreneurship literature by suggesting distinctive leadership characteristics required for becoming the leader in early-stage social ventures. Second, this study contributes to human capital theory by discussing specific human capital that contributes to the CEO emergence in social entrepreneurship context. Research in social entrepreneurship has investigated the influence of human capital on opportunity recognition pattern and willingness to start social ventures, but only few studies have related human capital to leadership emergence in social entrepreneurship contexts. Third, this study contributes to gender issues in the entrepreneurship literature by showing how gender affects leader appointments in a social venture context. Using expectancy violation theory, this study suggests that people with a background in countervailing gender bias are more likely to be seen as leaders than people with stereotype-consistent background.

\section{THEORETICAL BACKGROUNDS AND HYPOTHESES}

\section{CEO Selection}

Classical works by Hambrick and Mason (1984) and Pfeffer (1983) have facilitated a major stream of executive succession literature in strategic management. Pfeffer (1983) argued that efforts to examine organizational phenomenon are too much 
concentrated on understanding unobservable psychological factors, and encouraged scholars to shift their focus on more structural and observable factors, such as organizational demographics. Along the same line, Hambrick and Mason (1984) developed their upper-echelons theory, which argued that organizational outcomes can be explained by background characteristics of management, including demographic attributes such as age, education, functional experience, and socioeconomic status (Magnusson \& Boggs, 2006). Ideas from upper-echelon theory had been extended within the field of strategic management and entrepreneurship, and generated tremendous research interests in executive succession studies associated CEO or Top Management Team (TMT) characteristics with organizational outcomes. Scholars have investigated how executive characteristics are related to corporate strategy (Westphal \& Fredrickson, 2001), insider/outsider succession (Zhang \& Rajagopalan, 2003), board characteristics(Garg et al., 2017), and firm characteristics (Guthrie \& Datta, 1997).

Despite tremendous research works on executive succession and its consequences in the post-succession era, relatively less academic attention has given to the events leading up to CEO selection (Cannella \& Shen, 2001; Zhang \& Rajagopalan, 2003). Specifically, most studies have used upper-echelons theory have not provided framework to compare individuals assigned as CEOs to candidates who were not selected (Magnusson \& Boggs, 2006), with only two exceptions. Based on executive successions at USA Fortune 200 companies, Magnusson and Boggs (2006) identified international experience as a crucial factor associated with the CEO appointment of large corporations. Additionally, recent work of Jung, Vissa, and Pich (2017) investigated how founding team members allocate task positions when they launch new ventures. Drawing on status 
characteristics theory, they found co-founders with high diffuse status cues of gender(male), ethnicity(white), or achievement (academic honors/occupational prestige) could predict the occupation of higher-ranked positions, such as CEO.

This study aims to contribute to the budding CEO selection literature in entrepreneurship by investigating the characteristics, including human capital and demographic characteristics, of co-founders who are considered for CEOs when founding team members launching social ventures. Social ventures are distinctive from traditional ventures or large corporations by its dual financial and social goal and strong orientation towards social innovation. Due to this uniqueness in nature of organization, social venture founding team members might rely on different criteria and process in the selection of their first CEO from commercial firms or charitable organizations. In the following section, I discuss characteristics of social venture CEO candidates that might affect the CEO appointment by taking the perspective of human capital theory.

\section{Human Capital Theory and Social Entrepreneurship}

Human capital represents the knowledge and skills that individuals bring to an organization (Dimov \& Shepherd, 2005). It is developed through education and previous experience and thus contributes to the firm's explicit and tacit knowledge. The fundamental argument of human capital theory is that the better the human capital within the firm, the better the firm's performance in particular tasks (Becker, 1975; Dimov \& Shepherd, 2005). Specifically, individuals' knowledge and experience increase their cognitive abilities, leading to more productive and efficient activities (Becker, 1975; Davidsson \& Honig, 2003). Therefore, entrepreneurs with greater or higher quality of human capital can better perceive and exploit opportunities for new value creation. 
Research in entrepreneurship has supported the positive effect of human capital on entrepreneurial outcomes, such as the start of entrepreneurship or self-employment, new venture formation, and new venture growth and survival (Davidsson \& Honig, 2003; Dimov \& Shepherd, 2005).

The human capital literature distinguishes between general human capital, typically acquired through formal education and overall life experience, and specific human capital, which is obtained via experience specific to a particular activity or context (Becker, 1975; Estrin, Mickiewicz, \& Stephan, 2016). Research efforts have mainly focused on how general human capital, including age, education, and years of work experience affect organizational outcomes. According to the literature, general human capital encourages motivation to engage in start-up activities (Davidsson \& Honig, 2003; Estrin et al., 2016) and increases the likelihood of fund-raising success (Gimmon \& Levie, 2010), venture performance (Beckman \& Burton, 2008; Davidsson \& Honig, 2003), and venture survival (Gimeno, Folta, Cooper, \& Woo, 1997).

However, recent arguments suggest that specific human capital, which is more closely related to creating value in a specific venture context but limited in its applicability across multiple industries, is likely a more proximal predictor of venture outcomes (Dimov, 2010). Specific human capital represents the degree of similarity between a new venture and the organization where the entrepreneur had previously worked (Gimeno et al., 1997). Specific human capital accrued through task-specific experiences helps entrepreneurs select knowledge more relevant to the firm's success, especially in cases where experience is both firm and industry specific (Kor, 2003; Scarlata, Zacharakis, \& Walske, 2016). Considering the dualistic nature of social 
ventures, I investigate two specific human capital of founders: prior commercial experience and prior social experience. These are associated with the venture's goal of social mission and of profit generation, respectively.

\section{Prior Commercial Experience and Leadership Emergence}

Even though social and traditional entrepreneurs differ in their ultimate goals and ways of creating value, they both need to acquire external resources in their organizations' early operation to move into the next step (Estrin et al., 2016). In particular, like commercial ventures, early-stage social ventures must acquire seed capital from external investors to create viable product or service (Dimov \& Murray, 2008) as most founders lack sufficient capital to finance projects in general (Gompers \& Lerner, 1998). The external financing of seed capital reduces the uncertainty of business circumstances and offers advantages where professional investors provide guidance and advice to new ventures (Dimov \& Murray, 2008; Gompers \& Lerner, 1998). Therefore, one of the primary duties of a social venture's first CEO is to attract financial resources from external investors.

Typical funding sources for early-stage social ventures are impact investors include social venture capitalists (SVCs), philanthropic venture capitalists (PhVC), and fellowship foundations (Nicholls, 2012) . These funding organizations aim to create social wealth by financially and strategically supporting organizations pursue social changes. The funding decision rules of impact investors are unique because of the dual goal and identity of organizations they support (Miller \& Wesley, 2010). For instance, assessment factors of SVCs include attributes unique to social ventures such as social mission, an entrepreneur's passion for social change, and community-based networks. In 
addition to these attributes, SVCs also importantly consider entrepreneurial and commercial attributes such as business experience, innovation capabilities, and educational prestige (Miller \& Wesley, 2010). Research provides empirical evidences that the greater the entrepreneur's management experience is, the less likely SVCs is to evaluate the venture as uncertain (Miller \& Wesley, 2010). Scholars also found that SVCs tend to put much weight on entrepreneurial and commercial attributes in decisions on social ventures to support (Miller \& Wesley, 2010; Scarlata \& Alemany, 2009; Scarlata et al., 2016). These findings imply that impact investors select social ventures that can be economically sustainable, because only economically sustainable social ventures can grow and survive and, consequently, create the intended social impact (Scarlata \& Alemany, 2009).

Past research provided both theoretical support and empirical evidence that founders' human capital conveys an important signal about ventures' potential for future performance, thus enhances fundraising performance (Hsu, 2007). To enhance the signaling of a social venture's economic viability to external investors, team members would importantly consider an individual's previous commercial experience in the CEO selection. Therefore, I propose that a founder's prior commercial experience might be of value in the social venture and will enhance the possibility of the founder becoming the CEO.

Hypothesis 1: A founder's prior commercial experience is positively related to the likelihood of the founder becoming the first CEO. 


\section{Prior Social Experience and Leadership Emergence}

Dees (2002) posited that a social mission forms the key distinction between social ventures and traditional ventures. Impact investors regard social ventures' mission, social entrepreneurs' authenticity and passion for social change, and ethical orientation as critical assessment factors in addition to dimensions related to entrepreneurial and commercial activities (Miller, Grimes, McMullen, \& Vogus, 2012). Social experience refers to an entrepreneur's previous work experience in government ministries or government agencies, or enterprises with a social aim, and of starting and managing an enterprise with the intention to make a social impact (Scarlata et al., 2016). By engaging in activities in such organizations, individuals can form role identities as social activists and accumulate relevant knowledge on solving societal problems and applying these solutions across multiple contexts. Thus, an entrepreneur's social experience can improve the credibility of the social venture as it can enhance the venture's ability to address its social mission.

The distinctive features of a CEO's knowledge and expertise can make the difference in social ventures' primary goals and orientation. Wry and York (2017) suggested that the CEO's role identity associated with knowledge and competencies in a particular domain likely determines the social venture's approach to address its social mission. For instance, CEOs with knowledge and competencies in social welfare areas tend to seek the maximization of social impact in opportunity development. These CEOs are less likely to lose sight of their purpose and values in the quest for organizational efficiency (Ebrahim, Battilana, \& Mair, 2014). Thus, a CEO’s social experience can 
affect the venture's credibility in its support of social mission and consequently affect the venture's chances of acquire funding from impact investors.

Considering the mission-oriented nature of social ventures, I suggest that a founder's social experience might increase team members' expectation on the founder's contributions to the venture's performance. Therefore, a founder's social experience might enhance the possibility of occupying the CEO position.

Hypothesis 2: A founder's prior social experience is positively related to the likelihood of the founder becoming the first CEO.

\section{Balanced Entrepreneurs and Leadership Emergence}

Some founders of social ventures have accumulated work experience in both the social and commercial sector. Wry and York (2017) called these social entrepreneurs "balanced entrepreneurs" as they hold multiple role identities relevant to different logics (Stryker, 1980). Research shows that past work roles often remain salient because people preserve knowledge, capabilities, and social relationships from previous jobs (Dokko, Wilk, \& Rothbard, 2009; Wry \& York, 2017). When prior knowledge and skills are similar to new knowledge related to the current task, new knowledge acquisition becomes easier (Levinthal, 1989; Unger et al., 2011).

Therefore, balanced entrepreneurs with both commercial and social sector experience can better adapt to the social entrepreneurship context and more effectively transfer knowledge from the previous workplace to the new setting, compared with entrepreneurs with either commercial or social work experience. This fast understanding 
creates a high expectation among team members about the balanced entrepreneur's potential contribution to the new venture. Furthermore, when an individual has past work experience in both commercial and social sectors and possesses role identities related to each area, founding team members form high expectations of the individual's capability to pursue two different goals at the same time. In line with the arguments so far, I suggest that when a founder is a balanced entrepreneur, the possibility of becoming the CEO is higher than when a founder has work experience only in either commercial or social sector.

Hypothesis 3: A founder who is a balanced entrepreneur is more likely to be the CEO than a founder with either prior social experience or commercial experience.

\section{Gender Stereotypes in Business, Entrepreneurship, and Leadership Emergence}

Even though the number of women occupying executive positions has been continuously increasing(Lee \& James, 2007), gender stereotypes, defined as a shared belief of the characteristics and attributes related to each gender (Gupta, Turban, Wasti, \& Sikdar, 2009), are still common in the business and entrepreneurship world (Lee \& James, 2007). The extant literature provides underpinnings for the shared belief that women are less competent and qualified than men to manage a successful business. For instance, investors show more skepticism and negative responses about new female CEOs' expertise and expected future contributions to the firm than the expertise and expected future contributions of male CEOs (Lee \& James, 2007). Moreover, female 
entrepreneurs tend to have more difficulty obtaining financial resources than their male counterparts (Brooks, Huang, Kearney, \& Murray, 2014; Buttner \& Rosen, 1989; FullerLove, Lim, \& Akehurst, 2006) because female entrepreneurs are seen as less competent and unwilling to take challenges from external investors (Gupta et al., 2009). Gender stereotypes also affect the status-organizing process within entrepreneurial teams (Berger \& Fişek, 2006; Chen, Peterson, Phillips, Podolny, \& Ridgeway, 2012; Jung, 2017). For instance, Jung, Vissa, and Pitch (2017) showed that in new commercial ventures, men are better placed to take a hierarchically high-ranked position, such as CEO, whereas women are likely to take a hierarchically low-ranked position, such as CMO or COO.

Overall, gender role theory (Ridgeway \& Correll, 2004) and the prior literature on gender stereotypes has theorized and empirically supported the notion that communal qualities related to feminine gender stereotypes (expressiveness, connectedness, relatedness, kindness, supportiveness, relationship-oriented) are considered inconsistent with qualities required for business success and thus less valued than qualities related to masculine gender stereotypes (independence, aggressiveness, autonomy, task-oriented). Categorization theory suggests that a judgment of another individual is made by the congruence between the person and prototype or exemplar (Fraser \& Lord, 1988; Neubert \& Taggar, 2004). In commercial organizations, including commercial ventures, agentic qualities believed to be more associated with masculine gender stereotypes are considered essential for success. Because of this common belief, men are more likely to be viewed as leaders in such contexts (Neubert \& Taggar, 2004), which results in maledominated tendencies in leadership positions in business. 
However, gender role theorists also posit that the biasing effect of gender status on self-other performance expectations varies across all situations (Ridgeway, 2001). The diagnostic value of gender status beliefs can vary depending on how salient and task relevant gender is in a situation compared with other social roles and status-valued social distinctions are salient for participants (Ridgeway, 2001; Wagner \& Berger, 1997). Thus, the negative effects of gender stereotypes in leadership emergence are context specific rather than universal. For instance, if positive social behaviors were to become especially important to a group's success, women might emerge as leaders more often because of their greater attention to group morale and positive interpersonal relations (Eagly \& Karau, 1991).

Characteristics in a workplace described as essentially feminine include heightened communication skills (especially the ability to be a good listener and empathetic), advanced intermediary skills (for negotiation and conflict resolution), welldeveloped interpersonal skills, and a soft approach to handling people (Appelbaum, Audet, \& Miller, 2003). These characteristics are consistent with the attributes needed to do charitable and noncommercial work (Alvord, Brown, \& Letts, 2004; Teasdale, Mckay, Phillimore, \& Teasdale, 2011). The Global Entrepreneurship Monitoring survey indicated that women are almost as likely as men (around four women for every five men) to be involved in social entrepreneurial activity (Teasdale et al., 2011). This ratio favorably compares with that of more than twice as many men as women in commercial entrepreneurial activity (Harding, 2007).

In sum, previous research has shown that women in the workplace tend to demonstrate better people-oriented leadership skills compared with men with better 
business-oriented leadership skills. Because of these differences, leadership skills associated with feminine characteristics tend to be highly valued in the social sector, whereas masculine leadership characteristics tend to be associated with success in the commercial sector. Social ventures have both commercial and social aspects within organizational boundaries, which makes it difficult to predict the role of the entrepreneur's gender in leadership emergence in social entrepreneurship.

\section{Moderating Influence of Gender on Leadership Emergence}

One of the distinctive characteristics of social ventures is their requirement to satisfy multiple stakeholders with varying claims (Lumpkin, Moss, Gras, Kato, \& Amezcua, 2013). For instance, for some social ventures, the beneficiaries of products/services are not the same as those who pay for products/services. Social ventures need to rely on both to generate community support, gain access to resources, and enable beneficiaries to enact positive social change (Lumpkin et al., 2013). After investigating leadership attributes in successful social entrepreneurship, Alvord et al. (2004) found that the capacities for bridging and adaptive leadership are present in most successful social ventures. Further, the leaders of social ventures are required to identify key stakeholders in creating the kind of transformational change they envision. They must develop strategies for overcoming challenges and strengthening allies. Overall, the leader's ability to form and maintain relationships with multiple stakeholders with different needs is essential for a social venture's venture.

To create the intended social impact, social ventures need to be economically sustainable (Lumpkin et al., 2013). Fundraising and profit generation are critical to the creation of social wealth as well as the social venture's long-term survival. Thus, 
commercial activities are crucial for sustaining the operation of social ventures. To be economically sustainable, social ventures have been increasingly utilizing commercial practices that generate revenue. However, too much focus on commercial activities can distract the venture from serving its social mission, leading to "mission drift." Therefore, a major challenge that social ventures often face is achieving the balance in resource allocation trade-offs between commercial activities and activities that directly advance their social missions. Further, new social venture leaders should strive to reconcile differences among founding team members, particularly their relative orientation toward social and commercial goal achievement (Almandoz, 2014; Battilana \& Dorado, 2010; Dimitriadis et al., 2017).

To summarize, ideal leaders in social ventures should be capable of managing multiple stakeholders with different needs and the delicate balance between social and financial goal. Managing multiple stakeholders requires a high level of communication and interpersonal skills, which are associated with female stereotypes, while focusing on economic sustainability requires a high level of task orientation, which is generally associated with male stereotypes. Accordingly, leader prototypes in social entrepreneurship are associated with aspects of both female and male stereotypes. In this case, how would an individual's gender be associated with the CEO selection in earlystage social ventures?

According to expectancy violation theory (Jussim et al., 1987; Prentice \& Carranza, 2002), individuals who display positive counter-stereotypical traits are evaluated more positively than those who display positive stereotype traits (Lanaj \& Hollenbeck, 2015; Schaumberg \& Flynn, 2017). For instance, people tend to respond 
more favorably to eloquent football players than eloquent members of an academic speech team (Bettencourt, Charlton, Dorr, \& Hume, 2001; Schaumberg \& Flynn, 2017) and they applaud male fashion writers more than female fashion writers(Bettencourt et al., 2001; Schaumberg \& Flynn, 2017). A violator is believed to have positive stereotype characteristics by nature of his or her group membership and positive counter-stereotype qualities by nature of his or her particular exhibition of these traits (Schaumberg \& Flynn, 2017). Therefore, people often offer the greatest status and prestige to an individual who is deemed to positively violate stereotypes of the group of which individual has a membership (Kark, Waismel-Manor, \& Shamir, 2012; Powell, Butterfield, \& Bartol, 2008). Therefore, in certain context, women who engage in more task-oriented behaviors are more likely to emerge as leaders even if the same behaviors are demonstrated by men as well (Lanaj \& Hollenbeck, 2015).

Typically, characteristics such as being competitive, risk taking, task-oriented, and agentic have been associated with male stereotypes and are believed to be consistent with the goals and motivations of commercial firms (Dimitriadis et al., 2017). Thus, women with prior commercial experience might be perceived as possessing attributes of male stereotypes, which are assumed lacking for women, in addition to attributes of female stereotypes consistent with gender. Yet, founding team members would predict men with prior commercial experience, whose background is consistent with gender, might prioritize profit generation over the achievement of the social mission. This is because men with commercial background are assumed to only have attributes related to male stereotype. Based on the argument so far, I suggest that women with prior commercial experience are more likely to emerge as CEOs than their men counterparts. 
Hypothesis 4: Gender will moderate the relationship between prior commercial experience and the likelihood of becoming the CEO such that female founders with prior commercial experience will be more likely to become CEOs than male founders with prior commercial experience.

Drawing on people's favorable response to positive expectancy violation, I argue that prior work experience in the social welfare sector positively signals men's higher capabilities for communication and service of both social and financial missions compared with women. Traditionally, gender role theory associates women with personal qualities, such as caring, communal, kind, and empathetic - attributes consistent with the goals and motivations of the social sector (Dimitriadis et al., 2017). Men with prior experience in the social sector might be seen to have qualities relevant to serving social goals in addition to agentic qualities related to male stereotypes appropriate for serving financial goals. However, women from a social sector background are believed to lean toward social motivations and goals when the organization requires a balance between social and financial goals. Thus, women founders with social sector background are less positively evaluated as ideal leaders by other team members than men from the same background. Taken together, I suggest that men with prior social experience are more likely to emerge as leaders than women with prior social experience. 
Hypothesis 5: Gender will moderate the relationship between prior social

experience and the likelihood of becoming the CEO such that male

founders with prior social experience will be more likely to become CEOs

than female founders with prior social experience.

\section{Gender of Balanced Entrepreneurs and Leadership Emergence}

Entrepreneurship research has stated that firms founded and run by women tend to have distinctive features from those created by men (Baron, Hannan, Hsu, \& Koçak, 2007). A meta-analysis by Eagly and Johnson (1990), which reviewed studies comparing the leadership styles of men and women, found that female leaders tend to adopt a more democratic and participative and less autocratic or directive style than male leaders (Kark et al., 2012). In the same vein, several studies showed that women are perceived, and perceive themselves, as using transformational leadership styles more than men (Bass, Avolio, \& Atwater, 1996; Kark, 2004; Rosener, 2001). For instance, Eagly et al. (2003) found that women were rated higher than men in factors related to transformational leadership, whereas men were rated higher on transactional leadership scales. Overall, research has supported the notion that female leaders tend to be seen as transformational leaders who foster positive interactions and trust relations among subordinates, share power and information, and encourage employees to subordinate their personal aims and interests to collective ends (Kark, 2004).

One of the desirable leadership qualities of leaders in social ventures is to build and manage a number of relationships with multiple stakeholders. Female leaders are expected to display the features of transformational leaders, such as savvy relationship 
skills, paying attention to the needs of people inside and outside the venture, and offering developmental support and coaching. Leaders with these characteristics are likely to manage well the various needs of investors, beneficiaries, and team members and to provide essential support to stakeholders. Accordingly, female founders with past experience in both social and commercial sectors are more likely to emerge as leaders than their male counterparts.

Hypothesis 6: Gender will moderate the relationship between balanced experience and the likelihood of becoming the CEO such that female balanced entrepreneurs are more likely to become CEOs than male balanced entrepreneurs.

\section{Model 2: Theoretical Model}

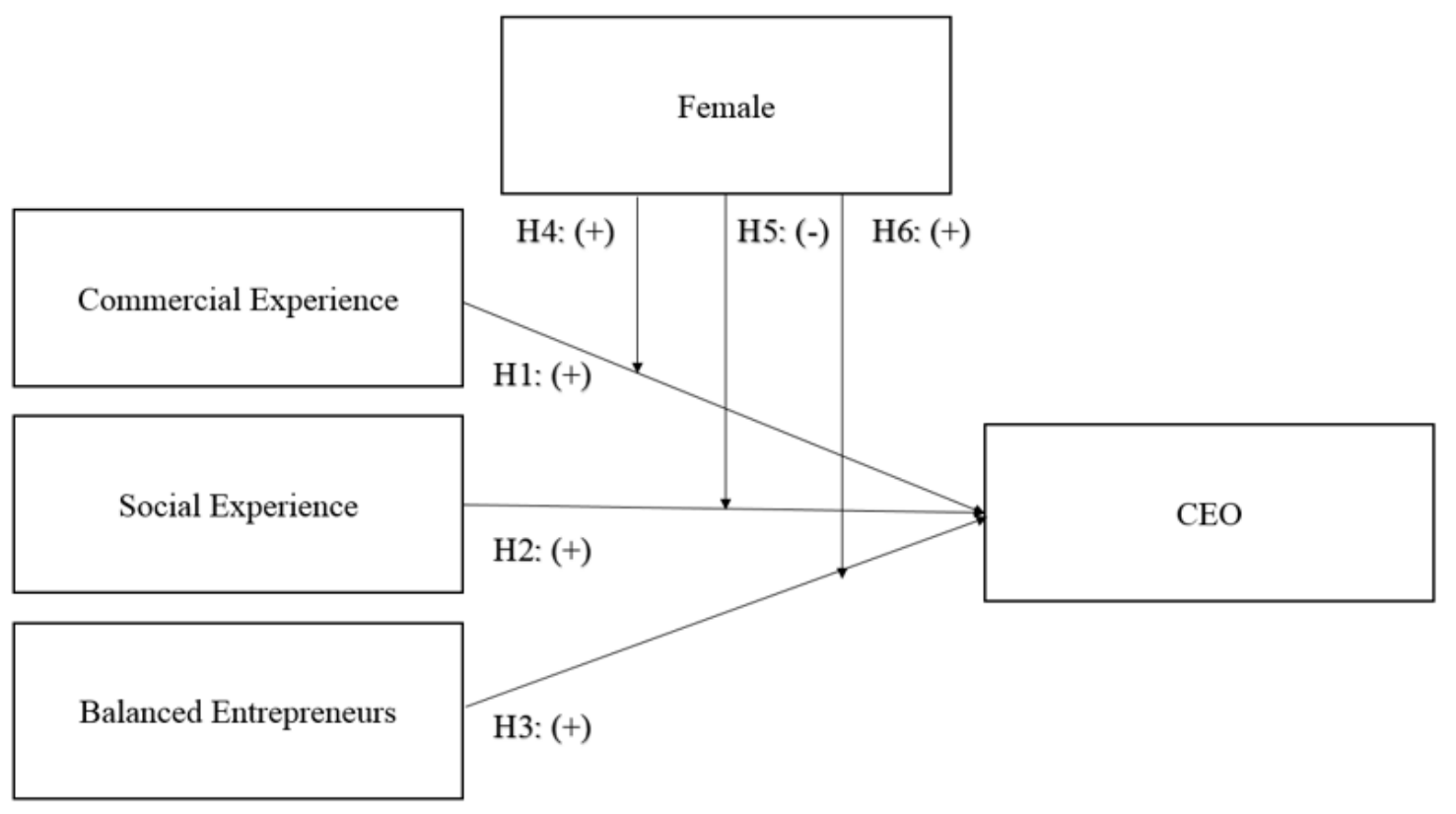




\section{METHODS}

\section{Sample}

Echoing Green is a 30-year-old non-profit grant-offering foundation, providing seed-stage funding and strategic support for promising early-stage social ventures to drive positive social change. Once a year, Echoing Green selects fellows with an innovative solution for diverse social issues, including poverty alleviation, food security, environmental problems, climate change, and social justice. Echoing Green has provided over \$36 million in seed-stage funding to social ventures in start-up phase, generally within the first two years of operations. Organizations still in the idea phase are also eligible to apply. Echoing Green takes a highly selective process for choosing promising social ventures. On average, Echoing Green receives more than 25,000 applications in a year, but only around 30 fellows are selected. The selection process is composed of multiple stages and includes online applications, essays, budgets, letters of reference, inperson pitches, and panel interviews. Currently in 2018, Echoing Green Fellows receive up to $\$ 90,000$ of unrestricted funding for their organizations that can be spent on anything, and can get the reimbursement for health insurance payments up to $\$ 4,000$ a year. Additionally, each Fellow receives \$1,000 a year for professional development.

Unlike other prominent impact investors, such as Ashoka, Skoll Foundation, and Schwab Foundation for Social Entrepreneurship that provide awards to leading social ventures with substantial social impact, Echoing Green identifies and supports emerging social entrepreneurs in their early-stages and help them to launch new organizations. As the primary focus of the current research is the founders of early-stage social ventures, I chose Echoing Green fellows from 1990 to 2017 for the investigation. Data is mainly collected from the Echoing Green website. As a supplemental source of information 
related to previous work experiences and founding motivations, I used social ventures' websites and LinkedIn, one of the largest business-oriented professional networking websites, and founders' interviews published in magazines and newspapers.

As this research aims to investigate leadership emergence in social ventures with social and financial objective, I only included founding team members of for-profit and hybrid social ventures in the sample. For-profit social ventures refer to entrepreneurial organizations that are legally incorporated as for-profit entities, but explicitly designed to serve a social purpose (Dees \& Anderson, 2003). While hybrid social ventures are nonprofit organizations but are operating commercial activities to profit generation within their structure. Even though for-profit and hybrid social ventures seemingly indistinctive in their objectives and operations, hybrids are legally not allowed to distribute economic profits to their stakeholders, as they are categorized as nonprofits. Initially, the sample includes 310 social entrepreneurs from 155 for-profit or hybrid social ventures.

As this study examines leadership emergence in a founding team, I excluded 49 one-person social ventures. For testing Hypothesis 1 to 3 , I used the sample of 261 social entrepreneurs from 108 social ventures. As the primary focus of Hypothesis 4 to 6 is related to social entrepreneurs' gender, I excluded 62 social ventures created by samegender founding teams. The sample used to test Hypothesis 4 to 6 includes 115 social entrepreneurs from 44 social ventures. Due to the missing information, the final sample for testing Hypothesis 1 to 3 includes the information of 241 social entrepreneurs, and the final sample for testing Hypothesis 4 to 6 includes the information of 111 social entrepreneurs. 


\section{Validity Check: Interrater Reliability}

Data was mainly collected and coded by the author according to coding protocol (Appendix B). Based on the information from sources, the author coded each founder's demographic data and other background information. Information of social ventures was obtained from multiple sources. However, the current study's research method can raise the question of consistency or agreement among the individuals collecting data due to the variability among human observers (Mchugh, 2012). The most credible way to address concerns of validity is to check interrater reliability: the results and differences among trained research assistants coding each set of information. To check interrater reliability, studies must include procedures that calculate agreement among data collectors. The study design needs to incorporate training the data collectors and measuring the extent to which they record the same scores for the same phenomena (Mchugh, 2012). Following suggestions from previous studies, I checked interrater reliability (Fleiss' kappa) for two indicators that required the judgment of coders, 'core founder' and 'primary motivation of founding a social venture,' before conducting the main analysis.

To examine the interrater reliability of two indicators that require a judgment, 'core founder' and 'primary motivation of founding a social venture,' the author and two research assistants (unfamiliar with this study's hypotheses) coded $20 \%$ of the data separately. First, coders identified the core founder in each founding team. A core founder refers to an individual who initiates the idea of establishing a venture and suggests the earliest outline of it (Wasserman, 2006) and ventures often have more than one core founder. Second, coders classified the motivation of each core fonder who primarily drives formation of the current social venture. After reading the founding story 
and core founders' interviews from articles, coders recognized whether core founders' motivation was triggered by specific personal experiences with the focal social problem.

The Fleiss' Kappa is an adaptation of Cohen's Kappa for three or more raters. A number of benchmarks for interpreting Kappa have been provided. Hartmann (1977) argues that Kappa values should exceed 0.6. Altman (1991) offered much detailed benchmark. Specifically, Kappa values lower than 0.2 is slight agreement, 0.21-0.4 is fair agreement, 0.41-0.6 is moderate agreement, 0.61-0.8 is substantial agreement, and higher than 0.81 is almost perfect agreement. He also mentioned that any value of Kappa below 0.5 would indicate poor agreement. Fleiss (1981) also presented benchmarks for interpreting Kappa; Poor: <.40, Intermediate to Good: .40 to .75 , Excellent: More than 0.75 (Fleiss, 1981; Gwet, 2014). The interrater reliability analysis shows that Kappa for 'core founder' is .67 , and 'primary motivation of founding a social venture' is .61. Both Kappa values exceed 0.6 and show good agreement or intermediate to good agreement.

\section{Dependent Variable}

CEO. Following the previous study (Jung, 2017), I created dummy variable for a founder's job title: When a founder is a Chief Executive Officer (CEO), 1 was given, and if a founder holds another job title, such as a Chief Operating Officer (COO), Chief Strategy Officer (CSO), or Chief Financial Officer (CFO), it was coded as 0. Among 43 social ventures in the sample, 4 social ventures have more than one CEOs.

\section{Independent Variables}

Prior commercial experience. A founders' prior commercial experience was conceptualized as a founder's work experience at commercial companies (Beckman \& 
Burton, 2008; Scarlata et al., 2016). It included a founder's occupational experience at venture capital (VC) firms, financial experience, senior management experience, consulting experience, entrepreneurial experience as a founder and an employee of a startup, and other work experience at commercially motivated firms (adapted from Scarlata et al., 2016). VC experience indicated core founders' prior experience of working in a traditional venture capital. Financial experience includes investment banking, options trading, commercial banking, and mutual fund portfolio management (Scarlata et al., 2016). Senior management experience includes work experience as CEO, $\mathrm{COO}, \mathrm{CSO}$, and $\mathrm{CFO}$ in companies where the focal individual is not a founder. The sum of months that spent on each experience was measured.

Prior social experience. Social experience indicates prior work experience in organizations with a primary social aim. Social experiences include a founder's prior work experience in SVCs or PhVCs, senior management experience at organizations with a social aim, government or government agencies, and founding experience or work experience at a venture with a social aim, and other work experience at organizations with a primary social aim (adapted from Scarlata et al., 2016). Senior management experience indicates work experience as $\mathrm{CEO}, \mathrm{COO}, \mathrm{CSO}$, and $\mathrm{CFO}$ in organizations with a social aim, where the focal individual is not a founder. Government experience indicates work experience in a government branch or for international governmental organizations aimed at promoting economic development and social progress. The sum of months that spent on each experience was measured.

Balanced entrepreneur. Balanced entrepreneurs concurrently hold salient role identities that align with commercial logic and social welfare logic (Wry \& York, 2017). 
Therefore, balanced entrepreneurs have occupational experiences in both commercial firms and organizations that aim to create social impact. A founder was categorized as a balanced entrepreneur when a person had more than 12 months of work experiences in both commercial and social area. Balanced entrepreneurs are coded as "1", and nonbalanced entrepreneurs are coded as " 0 ".

\section{Moderator}

Gender. Each founder's gender was coded as dummy variable: male $=0$; female $=1$.

\section{Control Variables}

Control variables were collected across three levels: a founder level, a founding team level, and a venture level. At a founder level, whether a founder is a core founder or not is measured and collected. Additionally, a founder's highest level of completed degree, elite education at undergraduate and graduate level, race/ethnicity, research experience, and motivation related to personal experience with the focal social problem were measured and controlled.

Among 106 social ventures that have more than one founding team members, majority has one core founder. Fourteen social ventures have two core founders, four social ventures have three core founders, and three social ventures have more than four core founders. Core founder is coded as " 1 ", and non-core founder is coded as "0". The founding team member's education was measured in two different ways. Firstly, the highest level of completed degrees was coded into one of following categories: $1=$ Bachelor's or less, $2=$ Master's, $3=$ Higher professional degrees. Organizational researchers posited that a manager's educational background, specifically attendance at 
certain school, can signal prominence (D’Aveni, 1990; Finkelstein, 2001). Thus, elite education is measured as well. Based on the list elite universities of Finkelstein (1992), the variable was coded as " 0 " when the entrepreneur did not attend elite school, and if he or she has undergraduate or post-graduate degree from elite school, it was coded as " 1 ". Race/ethnicity was coded into one of following categories: White $=1$, Otherwise $=0$.

Research experience refers to prior research experience at an educational institution, government agencies, or other research institution, and months spent on these organizations are coded.

At the founding team level, the founding team's size and task-relevant diversity based on team members' functional experiences and sectors are assessed and controlled. Prior functional experience was based on the team members' previous three jobs (Beckman, Burton, \& O’Reilly, 2007). The Shannon index is calculated as $-\sum P i(\ln P i)$, for $\mathrm{i}=1$ to $\mathrm{x}$, where $\mathrm{x}$ is the number of categories, and $\mathrm{Pi}$ is the proportion of team members with experience in category i. Adapting the previous study (Beckman et al., 2007), I used eight functional categories (production and operations, R\&D, and engineering, accounting and finance, management and administration, sales and marketing, law, personnel and labor relations, and others). Lastly, at the venture level, organizational type (hybrid, for-profit) was coded and controlled. Hybrid social ventures are coded as 0 , and for-profit social ventures are coded as 1.

\section{Analysis}

Data in this study was analyzed using logistics regression analysis (Hennart, 1997; Hair, Anderson, Tatham, \& Black, 1995). For testing hypotheses regarding the moderating role of gender, I used inteff command in STATA (Ai \& Norton, 2003; 
Norton, Wang, \& Ai, 2004). Prior to running the logistics regression, a correlation analysis was prepared (Table 1). None of the significant correlations appears to be high enough to demand concern about multicollinearity (Hair et al., 1995).

Table 1: Descriptive Statistics and Correlations

\begin{tabular}{|c|c|c|c|c|c|c|c|c|c|c|}
\hline & Variables & Mean & SD & 1 & 2 & 3 & 4 & 5 & 6 & 7 \\
\hline 1 & $\mathrm{CEO}$ & 0.47 & 0.50 & 1.00 & & & & & & \\
\hline 2 & Commercial experience & 33.93 & 57.29 & -0.08 & 1.00 & & & & & \\
\hline 3 & Social experience & 23.13 & 38.60 & $0.19 * *$ & -0.11 & 1.00 & & & & \\
\hline 4 & Balanced entrepreneur & 0.20 & 0.40 & 0.03 & $0.31 * *$ & $\begin{array}{l}0.30 * \\
*\end{array}$ & 1.00 & & & \\
\hline 5 & Female & 0.32 & 0.47 & 0.07 & -0.12 & 0.04 & -0.02 & 1.00 & & \\
\hline 6 & Core founder & 0.61 & 0.49 & $0.53 * *$ & $0.22 * *$ & 0.07 & -0.06 & 0.06 & 1.00 & \\
\hline 7 & Research experience & 9.63 & 32.24 & -0.07 & -0.01 & 0.04 & 0.07 & -0.04 & 0.02 & 1.00 \\
\hline 8 & Elite School & 0.60 & 0.49 & $0.12 *$ & -0.10 & -0.05 & -0.03 & $0.12 *$ & 0.10 & -0.03 \\
\hline 9 & $\begin{array}{l}\text { Highest level of completed } \\
\text { education }\end{array}$ & 1.70 & 0.71 & -0.00 & -0.03 & 0.06 & 0.03 & 0.02 & -0.04 & $\begin{array}{l}0.41 * \\
*\end{array}$ \\
\hline 10 & Race & 0.50 & 0.50 & 0.04 & $\overline{0}-17 * *$ & $0.14^{*}$ & 0.01 & -0.00 & -0.02 & -0.04 \\
\hline 11 & Founding motivation & 0.14 & 0.35 & 0.07 & 0.05 & -0.07 & -0.10 & -0.13 & $0.13 *$ & -0.05 \\
\hline 12 & Team functional diversity & 2.34 & 1.32 & $-0.14 *$ & $0.24 * *$ & $0.15^{*}$ & $\begin{array}{l}0.32 * \\
*\end{array}$ & -0.03 & $-0.14 *$ & 0.05 \\
\hline 13 & Founding team size & 2.73 & 1.01 & $-0.23 * *$ & -0.00 & -0.08 & -0.00 & -0.08 & $-0.13^{*}$ & 0.09 \\
\hline 14 & Organization type & 0.49 & 0.50 & -0.06 & -0.04 & 0.01 & 0.04 & -0.03 & -0.09 & 0.10 \\
\hline
\end{tabular}

Note: $N=241 * p<.05 * *_{p}<.01$

(cont'd)

\begin{tabular}{|c|c|c|c|c|c|c|c|c|}
\hline & Variables & 8 & 9 & 10 & 11 & 12 & 13 & 14 \\
\hline 8 & Elite School & 1.00 & & & & & & \\
\hline 9 & $\begin{array}{l}\text { Highest level of completed } \\
\text { education }\end{array}$ & $0.13^{*}$ & 1.00 & & & & & \\
\hline 10 & Race & $0.14 *$ & 0.04 & 1.00 & & & & \\
\hline 11 & Founding motivation & $-0.17 * *$ & -0.03 & $-0.35^{* *}$ & 1.00 & & & \\
\hline 12 & Team functional diversity & -0.11 & 0.11 & -0.11 & -0.06 & 1.00 & & \\
\hline 13 & Founding team size & 0.03 & 0.05 & -0.08 & -0.08 & $0.30^{* *}$ & 1.00 & \\
\hline 14 & Organization type & -0.03 & $0.16^{*}$ & -0.03 & 0.05 & $0.31 * *$ & -0.11 & 1.00 \\
\hline
\end{tabular}

Note: $N=241 * p<.05 * *_{p}<.01$ 


\section{RESULTS}

Three tests were ran to examine the impact of previous work experience and demographic background for the CEO emergence together and separately. Table 2 reports the results of hypotheses testing. Hypothesis 1 predicted that a founder's commercial experience would increase the possibility of becoming the CEO. The coefficient on the commercial experience indicator variable in Model 2 of Table 2 is not statistically significantly, thus failing to support Hypothesis 1 . Hypothesis 2 proposed that a founder's social experience would contribute to becoming the CEO. The coefficient on the social experience indicator variable in Model 2 of Table 2 is positive and significant $(\mathrm{p}<.01)$, supporting Hypothesis 2. Figure 1 displays the main effect of social experience on the possibility of becoming the CEO. Hypothesis 3 argued that when a founder has working experiences in both commercial firms and organizations with a primary social aim, the founder is likely to be the CEO. The coefficient on balanced entrepreneur indicator variable in Model 2 of Table 2 is not significantly significant, thus Hypothesis 3 is not supported.

Figure 1: Main Effects of Social Experience on the Predicted Probability of becoming CEO

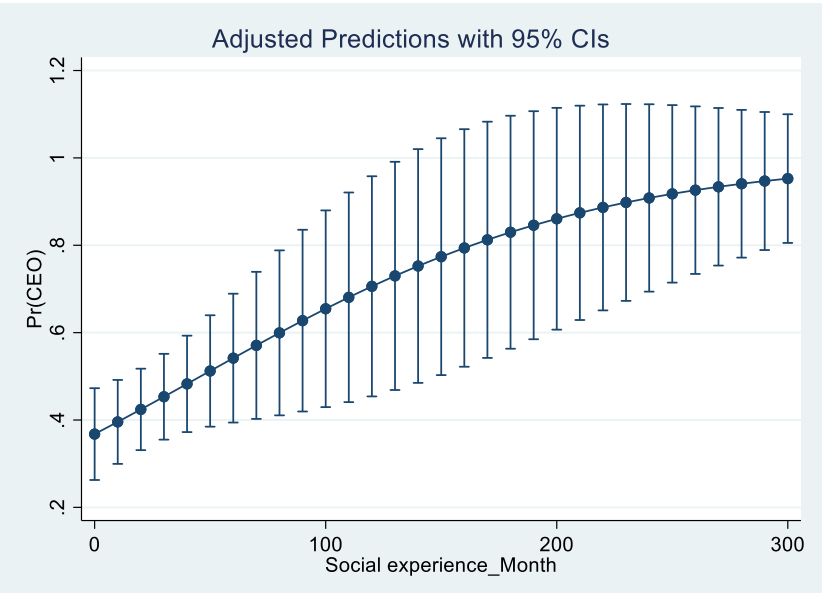

Note. Vertical lines are $95 \%$ confidence intervals. 
Table 2: Results of Logistics Regression

\begin{tabular}{|c|c|c|c|c|}
\hline & \multicolumn{4}{|c|}{ Dependent variable: $\mathrm{CEO}=1$, Otherwise $=0$} \\
\hline & Model 1 & Model 2 & Model 3 & Model 4 \\
\hline & Control model & Main effects & Individual level & Interactions \\
\hline \multicolumn{5}{|l|}{ Control variables } \\
\hline Core founder & $\begin{array}{c}2.516 * * * \\
(0.000)\end{array}$ & $\begin{array}{c}2.760 * * * \\
(0.000)\end{array}$ & $\begin{array}{c}2.97 * * * \\
(0.000)\end{array}$ & $\begin{array}{l}3.696 * * * \\
(0.000)\end{array}$ \\
\hline Female & $\begin{array}{l}-0.024 \\
(0.944)\end{array}$ & $\begin{array}{l}-0.085 \\
(0.814)\end{array}$ & $\begin{array}{l}-0.866 \\
(0.276)\end{array}$ & $\begin{array}{l}-1.804 * * \\
(0.062)\end{array}$ \\
\hline Race & $\begin{array}{c}0.115 \\
(0.735)\end{array}$ & $\begin{array}{c}0.007 \\
(0.984)\end{array}$ & $\begin{array}{l}-0.282 \\
(0.624)\end{array}$ & $\begin{array}{l}-0.229 \\
(0.738)\end{array}$ \\
\hline Founding motivation & $\begin{array}{c}0.140 \\
(0.774)\end{array}$ & $\begin{array}{c}0.204 \\
(0.693)\end{array}$ & $\begin{array}{c}0.948 \\
(0.322)\end{array}$ & $\begin{array}{c}0.515 \\
(0.637)\end{array}$ \\
\hline Research experience & $\begin{array}{l}-0.005 \\
(0.473)\end{array}$ & $\begin{array}{l}-0.008 \\
(0.251)\end{array}$ & $\begin{array}{l}-0.009 \\
(0.538)\end{array}$ & $\begin{array}{l}-0.012 \\
(0.476)\end{array}$ \\
\hline $\begin{array}{l}\text { Highest educational } \\
\text { degree= Master's degree }\end{array}$ & $\begin{array}{l}0.684 \dagger \\
(0.057)\end{array}$ & $\begin{array}{l}0.690 \dagger \\
(0.063)\end{array}$ & $\begin{array}{c}0.872 \\
(0.191)\end{array}$ & $\begin{array}{c}1.043 \\
(0.170)\end{array}$ \\
\hline $\begin{array}{l}\text { Highest educational } \\
\text { degree=PhD or } \\
\text { Professional degree }\end{array}$ & $\begin{array}{c}0.174 \\
(0.753)\end{array}$ & $\begin{array}{c}0.531 \\
(0.374)\end{array}$ & $\begin{array}{c}0.505 \\
(0.604)\end{array}$ & $\begin{array}{c}1.418 \\
(0.231)\end{array}$ \\
\hline Elite education & $\begin{array}{c}0.260 \\
(0.449)\end{array}$ & $\begin{array}{c}0.321 \\
(0.372)\end{array}$ & $\begin{array}{c}0.305 \\
(0.601)\end{array}$ & $\begin{array}{c}1.127 \\
(0.121)\end{array}$ \\
\hline Founding team size & $\begin{array}{c}-0.477 * * \\
(0.009)\end{array}$ & $\begin{array}{l}-0.403^{*} \\
(0.029)\end{array}$ & & $\begin{array}{l}-0.900 * * \\
(0.006)\end{array}$ \\
\hline $\begin{array}{l}\text { Team functional } \\
\text { diversity }\end{array}$ & $\begin{array}{l}-0.088 \\
(0.544)\end{array}$ & $\begin{array}{l}-0.254 \\
(0.118)\end{array}$ & & $\begin{array}{l}-0.422 \\
(0.173)\end{array}$ \\
\hline Organization type & $\begin{array}{l}-0.160 \\
(0.277)\end{array}$ & $\begin{array}{c}0.096 \\
(0.797)\end{array}$ & & $\begin{array}{c}0.086 \\
(0.909)\end{array}$ \\
\hline \multicolumn{5}{|l|}{ Independent variables } \\
\hline Commercial experience & & $\begin{array}{c}0.004 \\
(0.163)\end{array}$ & $\begin{array}{l}-0.031 \dagger \\
(0.064)\end{array}$ & $\begin{array}{l}-0.025 \\
(0.158)\end{array}$ \\
\hline Social experience & & $\begin{array}{l}0.017 * * \\
(0.006)\end{array}$ & $\begin{array}{c}0.003 \\
(0.837)\end{array}$ & $\begin{array}{c}0.008 \\
(0.620)\end{array}$ \\
\hline Balanced entrepreneur & & $\begin{array}{c}0.033 \\
(0.944)\end{array}$ & $\begin{array}{c}1.898 \\
(0.205)\end{array}$ & $\begin{array}{c}1.374 \\
(0.402)\end{array}$ \\
\hline \multicolumn{5}{|l|}{ Interactions } \\
\hline $\begin{array}{l}\text { Commercial experience } \\
\text { X Female }\end{array}$ & & & $\begin{array}{c}0.071 * * \\
(0.006)\end{array}$ & $\begin{array}{c}0.075^{* *} \\
(0.007)\end{array}$ \\
\hline $\begin{array}{l}\text { Social experience } \mathrm{X} \\
\text { Female } \\
\text { Balanced entrepreneur } \mathrm{X} \\
\text { Female }\end{array}$ & & & $\begin{array}{l}0.019 \\
(0.275) \\
-3.154 \dagger \\
(0.089)\end{array}$ & $\begin{array}{l}0.018 \\
(0.412) \\
-1.726 \\
(0.410)\end{array}$ \\
\hline $\begin{array}{l}\text { df } \\
\text { LR } x^{2} \\
\text { Log likelihood } \\
\text { Pseudo } R^{2} \\
\text { Observations }\end{array}$ & $\begin{array}{c}11 \\
87.97 * * * \\
-125.10 \\
0.26 \\
245\end{array}$ & $\begin{array}{c}14 \\
99.56^{* * *} \\
-116.80 \\
0.30 \\
241\end{array}$ & $\begin{array}{c}14 \\
58.65 * * * \\
-46.60 \\
0.39 \\
111\end{array}$ & $\begin{array}{c}17 \\
72.78 * * * \\
-39.63 \\
0.48 \\
111\end{array}$ \\
\hline
\end{tabular}

Notes: $* * * p<0.001 * * p<0.01, * p<0.05, \dagger p<0.10$ 
Hypothesis 4 predicted that female founders with prior commercial experience will be more likely to become CEOs than male founders with prior commercial experience. The coefficient of the interaction between commercial experience and female gender in Model 3 of Table 2 is positive and statistically significant $(\mathrm{p}<.01)$. Figure 2 describes differing effects of gender on the relationship between commercial experience and the possibility of becoming the CEO. In Hypothesis 5, I argued that male founders with prior social experience will be more likely to become CEOs than female founders with prior social experience. The coefficient on the interaction between social experience and female in Model 3 of Table 2 is not statistically significant, thus failing to support Hypothesis 5. Hypothesis 6 predicted that female balanced entrepreneurs are more likely to be the first CEO than their male counterparts. The coefficient on the interaction between balanced entrepreneur and female is negative and statistically significant ( $<<0.5)$, thus failing to support Hypothesis 6.

Figure 2: Interaction Effects of Commercial experience and Gender on the Predicted Probability of becoming CEO

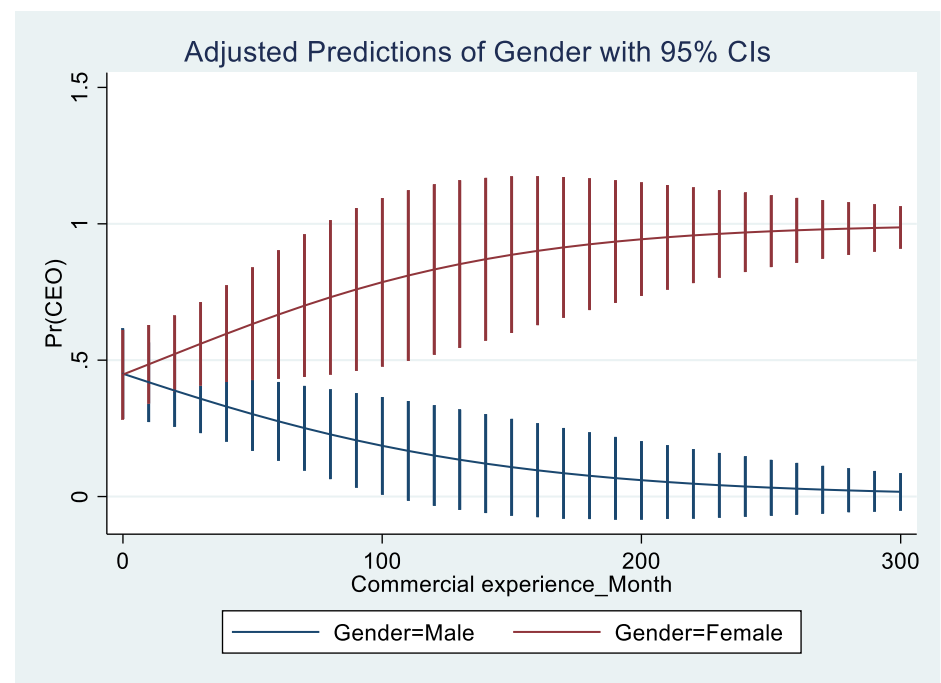

Note. Vertical lines are $95 \%$ confidence intervals. 
However, as noted by Ai and Norton (2003), the impact of an interaction in a nonlinear model is not simply the coefficient for the interaction. Because there are two additive terms and each can be positive or negative, the interaction effect may have different signs for different values of covariates. In this case, besides the interpretation of the significance of the z-statistics of the coefficient, a graphical presentation of the interaction term for the different observations is almost required (Hoetker, 2007; Mazzola, Perrone, \& Kamuriwo, 2015). Therefore, I use the Norton, Wang, and Ai (2004)'s methodology (inteff command in STATA) which recommended for computing the marginal effects of interaction terms in logit models.

\section{Figure 3: Interaction Effects of Commercial Experience and Female Gender after Logit} Regression
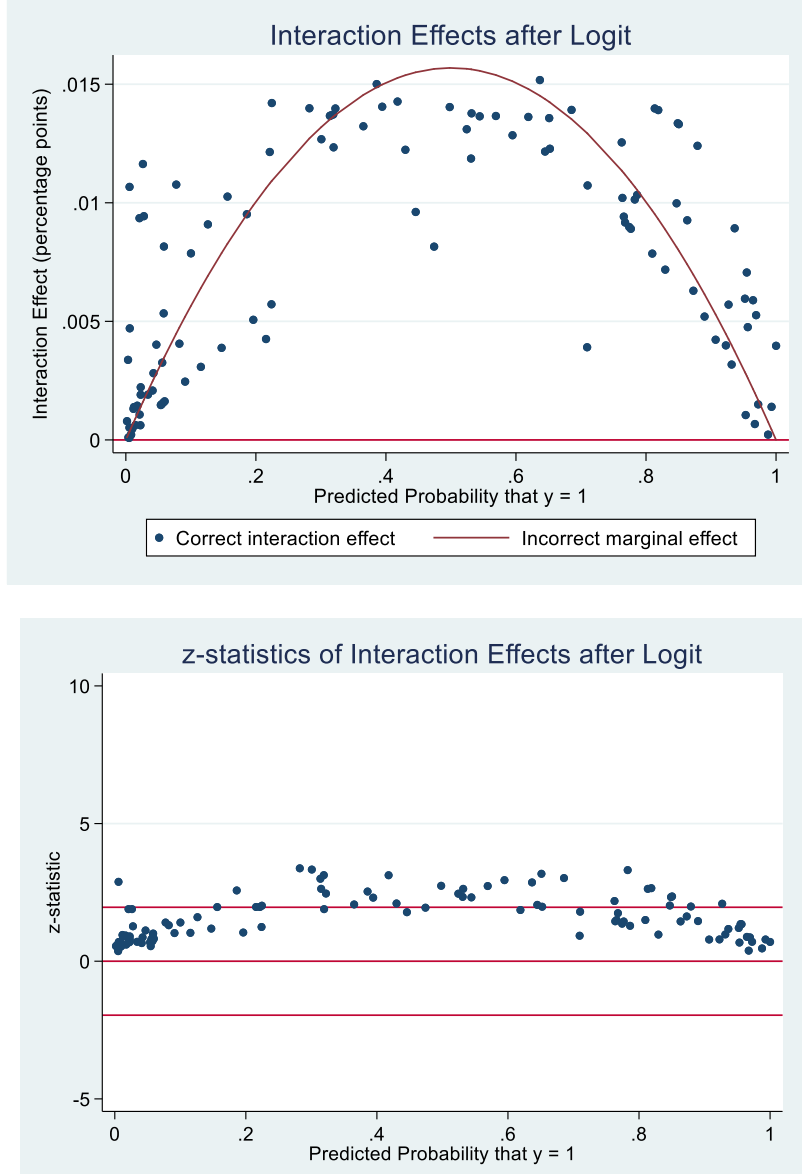
In Figure 3, the interaction term between commercial experience and gender is positive for all observations, which confirms that there exists positive interaction effect. Also, the sign of the z-statistics of all observations are positive. Additionally, the zstatistics significance is quiet good; looking at Figure 4, most of observations of individuals whose possibility of becoming the CEO is between 0.2 and 0.8 , the zstatistics are above the red line delimiting the significance. Therefore, the interaction effect is positive, and statistically significant. It broadly confirms the support for Hypothesis 4.

Figure 4: Interaction Effects of Social Experience and Female Gender after Logit Regression
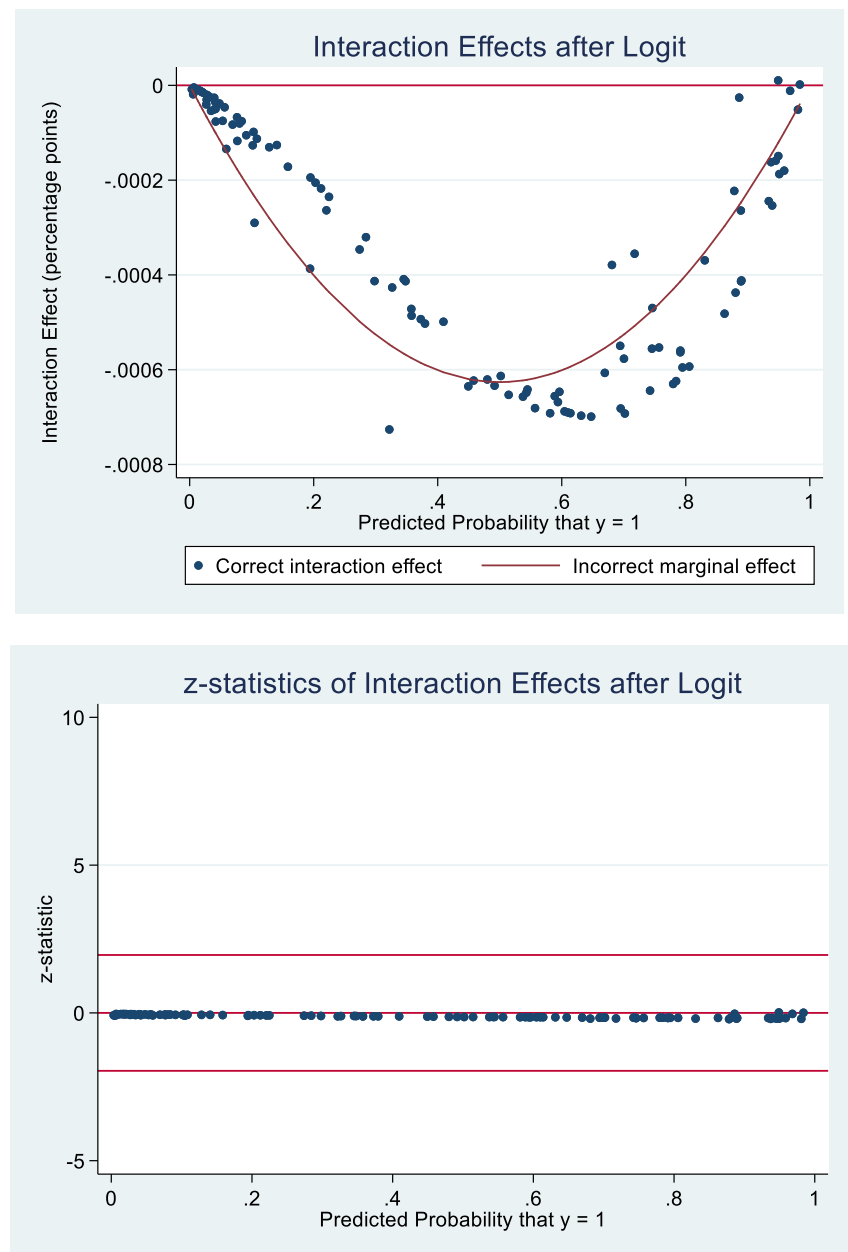
Figure 4 presented for the interaction effects of social experience and gender on the possibility of becoming the CEO. For most founding team members the interaction term is negative, but z-statistics graph shows that the interaction term is not statistically significant. It confirms the rejection for Hypothesis 5. Figure 5 shows the interaction effect between balanced entrepreneur and gender on the possibility of becoming CEO. All observations are positive and statistically insignificant, which confirms the rejection for Hypothesis 6.

Figure 5: Interaction Effects of Balanced Entrepreneur and Female Gender after Logit Regression
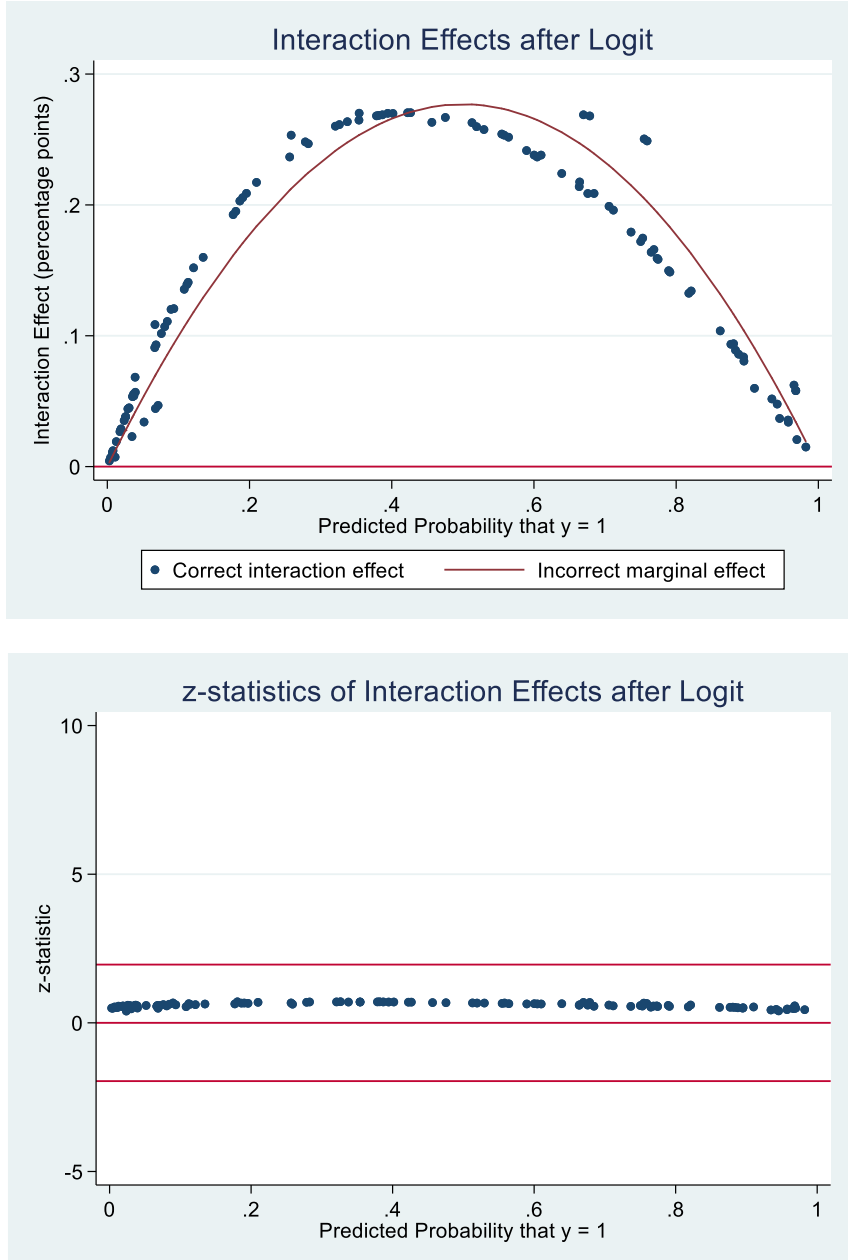


\section{DISCUSSION}

Research on leadership emergence has offered useful insights into how an individual's capability is perceived by others and contributes to acquire high status within a group. Extant literature has suggested that group members determine who is best suited to engage in leadership through a prototype-driven comparison process (Wellman, 2017). Specifically, scholars associated leadership emergence with each group's prototype of the ideal leader and proposed that when members of the group perceive an individual as having more of the same characteristics as the prototype, he or she is more likely to be seen as a leader (Wellman, 2017). While leadership emergence literature provides a meaningful answer to the question of why some people emerge as leaders and others do not, it does not fully address differences in team contexts, which can greatly influence how a group envisions the team prototype.

To advance our understanding of leadership emergence in the team and the social entrepreneurship context, I suggest hypotheses related to when an individual within a founding team becomes the first $\mathrm{CEO}$ of a social venture. Following the premise of extant literature, I assume that a team member whose characteristics mostly overlap with the ideal leader prototype in social entrepreneurship is most likely to become the first CEO. Drawing upon human capital theory and expectancy violation theory, I propose that task-relevant human capital — prior commercial experience and prior social experienceand a founder's gender may work as critical cues of leader attributes. Based on configurations of human capital and gender, the likelihood of a founder becoming the CEO would diverge. 
Results showed that the most important human capital element to become a leader in a social venture is prior social experience; the role of commercial experience and balanced background were not salient. It shows that even for hybrid or for-profit social ventures with a goal of profit generation, founding team members tend to consider social sector experience as a crucial factor to become a leader. This could be due to the social venture's need to enhance the legitimacy in its early-stage. As Dees (1998) mentioned, the most essential element of the social venture is its social mission. To enhance the legitimacy as an organization with a primary social goal, social venture founding teams might want to choose a leader who can strengthen the venture's identity as a social mission-oriented organization and can expound the organization's social goal.

Additionally, consistent with the expectancy violation theory, findings show that female founders' commercial experience amplify her probability of becoming the CEO. On the other hand, male founders' social experiences do not have any influence on the probability of becoming the CEO. This finding indicates that positive violation of gender stereotypes helps only female founders to emerge as leaders in social ventures, while do not help male founders. I believe the results of this paper provide rich opportunities for the future research.

\section{Theoretical Implications}

The current research makes theoretical contributions to the literature on social entrepreneurship and leadership emergence by offering a framework to comprehend the first CEO assignment of social ventures. First, this study extends human capital theory by suggesting that the specific human capital of social entrepreneurs is related to chances of becoming the CEO in the early-stage of a social venture. To best address the social 
venture's goal, the ideal leader must manage the different needs of stakeholders and maintain the delicate balance between the social and financial goal (Lumpkin et al., 2013). Although social ventures need to apply business models to serve a social mission, previous work experiences accrued from the social sector turned out to be the most crucial factor for becoming the first CEO. The finding also indicates that social experience of a core founder is even much important than having work experiences in both commercial firms and social mission-oriented organizations. It implies that in the early stage, social ventures tend to concentrate on identifying and solidifying their social mission rather than improving their capability for profit generation or fundraising.

This study also contributes to the gender in entrepreneurship literature by suggesting that leadership over-emergence of a specific gender does not occur in the social entrepreneurship context. Entrepreneurship literature has shown that female entrepreneurs tend to encounter more difficulties in acquiring access to external financial resources because investors are more likely to associate the physical characteristics of female entrepreneurs with their level of general capability as compared with their male counterparts (Brooks et al., 2014; Buttner \& Rosen, 1989; Fuller-Love et al., 2006). Due to this tendency, leadership positions in entrepreneurial organizations are typically dominated by men. The current study shows that this tendency differs in social entrepreneurship. Results indicate women entrepreneurs' commercial experience is valued as appropriate quality as leaders by social venture founding teams, while men entrepreneurs' commercial experience is not. This aligns with prior argument from literature: the impact of gender on outcomes is context-specific and varies depending on valued qualities in a specific environment (Eagly \& Karau, 1991; Ridgeway, 2001). 


\section{Practical Implications}

This study has managerial implications for social entrepreneurs who compete for the CEO position now or in future. By looking at the first CEO selection in social ventures, this study identifies and explores the type of human capital that contributes to the first CEO appointment. The finding shows that the social experience of a founding team member has a significant impact on becoming the CEO, which implies that acquiring legitimacy in the area is the most crucial task for early-stage social ventures. It also indicates that initial social ventures are primarily oriented towards social mission in general rather than making the balance between social mission and profit generation. Furthermore, only for female founding team members, previous working experiences in the commercial sector can enhance her possibility of becoming the CEO. Social venture founding teams tend to positively assess the commercial background of female team members and view it as a leadership quality. This result has implications in particular for female social entrepreneurs who strive for the leadership position within early-stage social ventures.

\section{Limitations and Future Research}

In this study, I only focus on leadership emergence, the first strategic decision that founding team members need to make in the social venture's early stage. Future research can extend the current study by investigating the long-term effect of the first CEO's dominant background on social ventures' decision-making pattern, survival rate, and performance in fundraising and economic sustainability. Specifically, it might be interesting and meaningful to examine how ventures led by CEOs with commercial backgrounds differs from a venture led by CEOs with social backgrounds. Due to social 
ventures' dualistic nature, the first CEO's background may largely affect the organization's orientation towards commercial activities and social mission, and it will have a lasting impact on the firms' future performance. Scholars have recognized that organizations differ from one another because of social imprinting (Stinchcombe, 1965; Johnson, 2007). According to social imprinting perspective, organizations differ from each other because they are shaped by economic, technological, and cultural resources that their founders drew from the founding context. These resources exercise a lasting influence on a wide variety of organizational features, including managerial structure, organizational network, and survival rate (Johnson, 2007). Social imprinting arguments can offer a profound theoretical framework to explore this phenomenon.

While the data of this study was directly collected from social entrepreneurs' background and motivation, I was unable to assess the decision-making process of social venture founding teams directly. Thus, scholars can take a more proximal approach to assessing founding team members' decision-making pattern, such as scenario analysis and computer simulation (Kish-gephart \& Campbell, 2015). Early-stage social ventures at incubators might be relatively accessible to reach than already established social ventures.

Another limitation of this study is its concentration on only for-profit and hybrid ventures and mixed-gender founding teams, which bounds generalizability of the finding. The data for this study excluded entrepreneurs in nonprofit social ventures or singlegender founding teams to focus on the leadership emergence in organizations with dual social and financial purpose in association with the gender of team members. I believe exploring the CEO selection patter using a different type of data from this study would 
allow researchers to create richer theoretical and empirical implications for leadership emergence and entrepreneurship literature. Specifically, a focus of nonprofit social ventures in their leader selection would be different from that of for-profit/hybrid social ventures. Further, expectedly, all-women founding teams and all-men founding teams might engage in different cognitive evaluations in their leader selection from mix-gender teams.

This study assumes that a social entrepreneur's personal experience with the focal social problem may affect a social venture's decision-making pattern, thus in the analysis I controlled for it. For a future research endeavor, scholars can explore the founding motivation of social entrepreneurs and its influence on organizational outcomes. The role of entrepreneurial motivation in entrepreneurial processes and outcomes has been widely explored in traditional entrepreneurship studies, but the long-term effect of social entrepreneurs' motivation is less commonly studied (Shane, Locke, \& Collins, 2003). For years, a few social entrepreneurship scholars have explored the question of why social entrepreneurs seek to create social ventures. However, most work has focused on either how intentions of engaging in social ventures are formed (Mair \& Martí, 2006) or the differences among social entrepreneurs in their fundamental reasons to initiate social entrepreneurship activities (Robinson, 2006). Social entrepreneurship is much more problem-solving focused than traditional ventures, thus how a social entrepreneur is related to the focal social problem can largely explain the social ventures' entrepreneurial process and performance (Yitshaki \& Kropp, 2016). Future research can further delve into this concept by taking the micro-foundations approach. For instance, scholars can examine how a social entrepreneur's founding motivation related to the social problem 
would affect a social venture's strategic choice, future performance, and survival rate. Additionally, future research can consider how the specific personal experience of a social entrepreneur can enrich the power of narratives. Narratives that well-describe social entrepreneurs' founding motivation can improve external resource providers' evaluations on the social ventures' legitimacy and authenticity towards the social mission (Yitshaki \& Kropp, 2016).

\section{CONCLUSION}

Leadership emergence literature suggests that team members with characteristics consistent with the general leadership prototype are likely to emerge as leaders due to perceptual congruence (Neubert \& Taggar, 2004; Wellman, 2017) . Drawing on human capital theory and expectancy violation theory, this study investigates the first CEO emergence occurring in early-stage social ventures, where members of groups determine who might be best suited as leader. By focusing on the characteristics of core founders and the situations of core founders becoming the first CEO, this study highlights unique aspects of leadership emergence in social ventures that simultaneously pursue social mission and commercial goal. When core founders had previously worked at social sectors, they were most likely to be perceived as leaders because their prior work experiences made group members perceive them as capable of serving the social mission. Additionally, women entrepreneurs' commercial experience is much favorably considered than men entrepreneurs' commercial experience in the first CEO selection. Overall, findings demonstrate that early-stage social venture founding teams are unique in their first leader selection, and it is strongly associated with distinctive characteristics of social entrepreneurship. 


\section{CHAPTER 4: ECHOING GREEN'S SURVIVAL STRATEGY AFTER THE FINANCIAL CRISIS IN 2008}

\section{INTRODUCTION}

Today, a number of fellowship programs support social entrepreneurship. These fellowship programs offered by foundations provide a great deal of approachable opportunities to early-stage organizations that primarily support social mission.

Foundations provide their fellows with seed capital to launch organizations that address their innovative ideas and help social entrepreneurs develop skills needed to be leaders in social entrepreneurship. Social entrepreneurs who were selected as fellows of foundations tend to show high survival rate. For instance, an evaluation study conducted by Ashoka in 2002 of 1997 fellows showed that $94 \%$ were survived after 5 years of successful

operation. Further, 70\% of Echoing Green-funded organizations from 1990-2015 are still in 2018. Overall, fellowship foundations contribute to the growth of social entrepreneurship by selecting and supporting promising talents with innovative ideas to tackle social problems.

Fellowship foundations are largely affected by economic fluctuations. One of primary macroeconomic challenges that most organizations went through was the recent global financial crisis in 2008. Financial crisis in 2008 leads to severe budget limitations for many nonprofit organizations due to less financial support from individual donators and governments (Peterson \& Su, 2017; Strom, 2009; Watkins, 2009). This hardship is further exacerbated for charitable organizations as the economic downturn creates more 
demands for their services (Peterson \& Su, 2017). It also resulted in tremendous change in fellowship foundations for social entrepreneurs, specifically in foundations' overall strategic decisions. These consequential changes include the foundation's way of financing, the choice of creating partnership, the composition of the board, and the allocation of the foundation's fellowship. In this paper, I explore how fellowship foundations responded to the increased call for funding and the diminishing financial sources after the downturn in the U.S. economy, by exploring a prominent fellowship foundation for early-stage social entrepreneurs, Echoing Green.

By investigating Echoing Green's strategic decisions in response to the financial crisis in 2008, the current paper aims to discuss the results and implications of the foundation's choices and provide knowledge on the effect of financial adversity to organizations in the area of social entrepreneurship. Specifically, I investigate strategic actions that Echoing Green foundation took in response to challenges derived from its financial challenges during the economic downturn in 2008. Echoing Green is a nonprofit public charity that selects Echoing Green Fellows and provides those Fellows with seed capital and non-financial support to help them succeed with their ventures (Battilana, DeLong, \& Weber, 2009). Echoing Green Fellows are social entrepreneurs-individuals who found and manage organizations aimed at solving social problems. Echoing Green Fellows have been implementing new ideas to address an environmental, economic, social, or political inequity problem (Battilana et al., 2009). Echoing Green had funded leading organizations in social entrepreneurship such as City Year and Teach for America in the United States, African Leadership Academy in Africa, and SKS Microfinance in Asia. In general, funding consisted of a two-year stipend that ranged from $\$ 30,000$ to 
$\$ 45,000$ per year, per organization in 2008 (Battilana et al., 2009; Battilana, DeLong, \& Weber, 2015). Strategic supports include leadership development, training, conferences, and networking opportunities designed to facilitate Fellows' success (Battilana et al., 2015). As Echoing Green was heavily backing young entrepreneurs who just graduated college or graduate school, strategic supports were especially crucial to help entrepreneurs create genuine social impact.

In late 2008, many Echoing Green's supporters reduced or deferred their donations due to the economic downturn. However, despite this adversity in 2008, Echoing Green was relatively successful in the field. It kept raising more money, selecting more fellows, and developing a new program. However, Echoing Green was facing another challenge - increased competition in the field. Echoing Green had been a lone pioneer in the field of social entrepreneurship for over 20 years. However, at that time it was on the verge of losing its leadership position as a number of organizations with similar missions and more resources come to the field, including Ashoka and the Skoll Foundation. From inside and outside, Echoing Green was facing a strong need to transform.

In this article, I examine Echoing Greens' strategic actions after the financial crisis 2008. In response to increasing demand of its services and competition in the field of social entrepreneurship, Echoing Green creates a number of partnerships to expand its program and focus. Echoing Green's strategic responses to the complicated internal and external challenges have an important implication for public charity and private foundations aimed at support social entrepreneurs. 
Table 3: Summary of Financial Data (\$, except the number of donors and public support percentage; fiscal year ends June 30 of the year indicated)

\begin{tabular}{|c|c|c|c|c|c|c|c|c|c|}
\hline & 2008 & 2009 & 2010 & 2011 & 2012 & 2013 & 2014 & 2015 & 2016 \\
\hline $\begin{array}{l}\text { Total } \\
\text { revenue }\end{array}$ & $4,261,335$ & $5,544,407$ & $3,568,391$ & $5,582,121$ & $8,438,807$ & $18,507,751$ & $9,000,301$ & $6,751,613$ & $6,153,472$ \\
\hline $\begin{array}{l}\text { Received } \\
\text { contributions }\end{array}$ & $4,214,870$ & $5,512,455$ & $3,502,438$ & $4,921,009$ & $7,602,156$ & $17,872,933$ & $8,653,858$ & $6,595,633$ & $6,053,339$ \\
\hline Grants paid & $1,205,854$ & $1,386,208$ & $1,334,251$ & $2,657,036$ & $2,719,351$ & $3,944,099$ & $4,160,060$ & $4,179,374$ & $3,321,048$ \\
\hline $\begin{array}{l}\text { Other } \\
\text { expenses }\end{array}$ & 221,836 & $1,069,771$ & $1,065,094$ & $1,503,002$ & $1,679,516$ & $2,061,580$ & $3,320,129$ & $2,900,182$ & $2,871,693$ \\
\hline $\begin{array}{l}\text { Total } \\
\text { expenses }\end{array}$ & $3,286,334$ & $3,576,391$ & $3,752,192$ & $6,028,990$ & $6,633,853$ & $9,119,916$ & $11,275,877$ & $10,924,236$ & $9,814,028$ \\
\hline $\begin{array}{l}\text { Excess } \\
\text { revenues } \\
\text { over } \\
\text { expenses }\end{array}$ & 975,001 & $1,968,016$ & $(183,801)$ & $(446,869)$ & $1,804,954$ & $9,387,835$ & $(2,275,465)$ & $(4,172,623)$ & $(3,660,556)$ \\
\hline Total assets & $3,913,315$ & $5,844,543$ & $5,784,569$ & $6,329,026$ & $8,465,263$ & $19,215,897$ & $17,728,888$ & $12,575,722$ & $9,138,988$ \\
\hline $\begin{array}{l}\text { Number of } \\
\text { donors }^{1}\end{array}$ & 87 & $\mathrm{n} / \mathrm{a}$ & 90 & 94 & $\mathrm{n} / \mathrm{a}$ & 106 & $\mathrm{n} / \mathrm{a}$ & $\mathrm{n} / \mathrm{a}$ & $\mathrm{n} / \mathrm{a}$ \\
\hline $\begin{array}{l}\text { Public } \\
\text { support } \\
\text { percentage }^{2}\end{array}$ & $\mathrm{n} / \mathrm{a}$ & $55.20 \%$ & $55.09 \%$ & $57.13 \%$ & $57.23 \%$ & $51.12 \%$ & $55.76 \%$ & $60.08 \%$ & $62.58 \%$ \\
\hline
\end{tabular}

Source: Echoing Green Form 990 (2008-2016).

\footnotetext{
${ }^{1}$ Represents the number of donors who contributed $\$ 5,000$ or more in that year.

${ }^{2}$ A 501(c)(3) organization is treated as a public charity for its current year and the next taxable year if, over five-year measuring period, one-third or more of its total support is public support from governmental agencies and qualifying contribution or grants from the general public and other public charities. (Source: http://www.nonprofitlawblog.com/public-support-tests-part-i-509a1/)
} 


\section{ECHOING GREEN'S EARLY HISTORY}

Echoing Green is a New York City-based fellowship organization that seeks the improvement of society by identifying and supporting social entrepreneurs who launched entrepreneurial organizations to tap into societal problems. Echoing Green selects fellows with great talents and ideas to solve the world's problems, supports fellows to enhance their odds of success, and attract donors by using fellows' stories of success to continue backing social entrepreneurs.

Echoing Green was established in 1987, in order to increase social impact by using venture capital investment model. Its roots can be found the philanthropic activities of Charles Feeney, a businessman and philanthropist and the founder of General Atlantic and Atlantic Philanthropies. In 1960, Feeney co-founded Duty-Free Shoppers Group (DFS), which pioneered the concept of duty-free shopping. Over several decades, he developed and managed the highly profitable business and created a tremendous wealth. However, he is known for his frugality, and enjoyed giving money away in secret. In 1982, Feeney created the Atlantic Philanthropies and also found General Atlantic as a private investment company to manage the assets of Atlantic Philanthropies (Battilana et al, 2015). General Atlantic hired Edward Cohen as the CEO.

In 1987, General Atlantic helped launch Echoing Green to generate a positive social impact by assisting young social entrepreneurs to start their ventures and solve the social problem. Cohen and professionals from General Atlantic evaluated candidates for Echoing Green Fellows as if they were evaluating a potential investment (Battilana et al., 2015). Over the 20 years, two major funding sources of Echoing Green had been General 
Atlantic and Atlantic Philanthropies. Cohen was often identified with Echoing Green and called as the early guiding force of the organization. After Cohen retired in 1995, Echoing Green was significantly suffered from his absence. The number of Fellows kept decreasing, and officers left the organization. In 2001, Echoing Green only supported five Fellows.

Obviously, Echoing Green was struggling to survive. Furthermore, in 2001, General Atlantic notified Echoing Green that it cannot continue supporting the organization anymore. At that point, Echoing Green hired Cheryl Dorsey, a previous Echoing Green Fellow in 1992 as the new president who will lead to transform the organization to survive. When Cheryl Dorsey was named as the president, there was almost nothing but great records of Echoing Green Fellows. In mid-2001, Echoing Green just had two full-time employees, and the organization was facing so much uncertainty around the future of the organization. Since Dorsey was named as the new president of Echoing Green in 2001, she has focused on developing a base of donors and reconstructing the organization almost from scratch (Battilana et al., 2015). To enhance the organization's strategic focus and sustainability, Dorsey brought in consultants who can help her to examine Echoing Greens' strategic options. In late 2006, Boston Consulting Group (BCG) outlined several options for Echoing Green. These options include 1) Stay the course, do not make any significant changes, 2) Grow the existing program - more fellows, potentially larger or longer funding from Fellows, more coaching and support of fellows, 3) Develop new programs (Battilana et al., 2015). Following their last two suggestions, Echoing Green expanded its focus on young fellows by launching new fellowship program called "Be Bold Initiative" in late 2006, which 
intended to inspire more young people to seek meaningful career in social sector.

Furthermore, Echoing Green increased the number of fellows and prepared itself for

developing new fellowship programs.

Over next six years, Dorsey built a more self-supporting organization (Battilana et al., 2015) and developed Echoing Green as global Fellowship program almost from scratch. Thanks to her leadership, Echoing Green could enhance its influence in the field of social entrepreneurship, and create a wide network of donors to support their philanthropic activities.

\section{Table 4. History of Echoing Green}

\begin{tabular}{|c|c|}
\hline Year & Event \\
\hline 1987 & $\begin{array}{l}\text { - Leadership of General Atlantic launches Echoing Green to maximize its } \\
\text { philanthropic impact. } \\
\text { Edward Cohen, the CEO of General Atlantic serves as Echoing Green's } \\
\text { chairman. }\end{array}$ \\
\hline 1991 & $\begin{array}{l}\text { - Echoing Green invests in Vanessa Kirsch, Founder of Public Allies, and later } \\
\text { provides support to Michelle Obama to run the Chicago office of Public Allies. }\end{array}$ \\
\hline 1995 & $\begin{array}{l}\text { - Edward Cohen retires in 1995, the number of Fellows selected each year began to } \\
\text { fall. }\end{array}$ \\
\hline 1996 & $\begin{array}{l}\text { - Fellow Sara Horowitz launches Working Today (now the Freelancers Union) - a } \\
\text { first of its kind national membership organization that offers benefits to freelancer } \\
\text { workers. The for-profit subsidiary, Freelancers Insurance Company, received a } \\
\$ 340 \text { million government grant in } 2012 \text { to establish nonprofit insurance } \\
\text { companies in three states. }\end{array}$ \\
\hline 2001 & $\begin{array}{l}\text { - Only five Fellows are selected in } 2001 . \\
\text { - Atlantic Philanthropies, one of the two major funding sources of Echoing Green, } \\
\text { notifies that it would not continue to support Echoing Green. } \\
1992 \text { Echoing Green Fellow Cheryl Dorsey becomes president of Echoing Green, } \\
\text { reshaping the organization into a global nonprofit. }\end{array}$ \\
\hline 2007 & $\begin{array}{l}\text { - Felix Brandon Lloyd, Founder of Skill-Life, is the first Fellow to apply with a for- } \\
\text { profit business model. Over the next five years, Echoing Green's Fellowship } \\
\text { portfolio averages } 38 \% \text { for-profit and hybrid business models. }\end{array}$ \\
\hline 2009 & $\begin{array}{l}\text { - Cheryl Dorsey and other notable Fellows serve on The Obama-Biden Presidential } \\
\text { Transition team and assist in standing up the first ever White House Office of } \\
\text { Social Innovation and Civic Participation. }\end{array}$ \\
\hline 2010 & $\begin{array}{l}\text { - SKS Microfinance, founded by } 1998 \text { Fellow Vikram Akula, becomes the largest } \\
\text { micro-lending company to go public in an IPO that raises over } \$ 350 \text { million. }\end{array}$ \\
\hline 2011 & $\begin{array}{l}\text { - } \\
\text { - } \quad \text { Ajay Nagpal, Managing Director at Barclays capital joins the board. } \\
\text { - } \quad \text { Echoing Green publishes Work on Purpose and launches a corresponding } \\
\text { program to help young people build careers that are right for them and good for } \\
\text { the world. }\end{array}$ \\
\hline
\end{tabular}




\begin{tabular}{|c|c|}
\hline 2012 & $\begin{array}{l}\text { - Echoing Green creates a partnership with the Open Society Foundation. } \\
\text { - In partnership with the Open Society Foundation, Echoing Green launches the } \\
\text { Black Male Achievement Fellowship, selecting nine Fellows that are improving } \\
\text { the life of black men and boys in the U.S. } \\
\text { - Robb Vorhoff, Managing Director at General Atlantics joins the board. } \\
\text { - Echoing Green co-authors "In Search of the Hybrid ideal" for the Stanford Social } \\
\text { Innovation Review and initiates a partnership with The Social Entrepreneurs } \\
\text { Fund, a multi-million dollars fund that supports Echoing Green's for-profit } \\
\text { Fellows. }\end{array}$ \\
\hline 2013 & - Echoing Green creates a partnership with Newman's Own Foundation. \\
\hline 2014 & $\begin{array}{l}\text { - Echoing Green creates a partnership with the Zoom Foundation. } \\
\text { - In partnership with the Zoom Foundation, Echoing Green launches the Climate } \\
\text { Fellowship, which is specifically targeted for next-generation social entrepreneurs } \\
\text { committed to working on innovations in mitigation and adaptation to climate } \\
\text { change. } \\
\text { - Echoing Green launches Inflection Cohorts to support Fellows facing key } \\
\text { opportunities to grow their organizations past their initial Fellowship. }\end{array}$ \\
\hline
\end{tabular}

Source: Adapted from Annual Reports (2010-2017) and 25th anniversary and highlights achievements (2012).

\section{STRATEGIC CHANGES AFTER THE FINANCIAL CRISIS: FROM A SINGLE PROGRAM TO A PLATFORM}

For the first time in 2007, Echoing Green selected a fellow relies on a for-profit

business model. Since then, the ratio of Echoing Green fellows fall back on for-

profit/hybrid models are continuously increasing. Additionally, after the financial crisis in

2008, social entrepreneurs began to seriously consider the way of generating revenues

that can sustain their operations and engage in commercial activities to continuously

pursue a social mission. The number of applications from these types of social ventures

was continuously increasing. For instance, in 2006, only $37 \%$ of applicants of Echoing

Green relied on for-profit/hybrid models, while in 2010, almost $50 \%$ relied on it. To call

the need of economically sustainable business model for social entrepreneurship, Echoing

Green announced that it will actively support for-profit/hybrid social ventures. From 
2007, the ratio of for-profit/hybrid social ventures got the support from Echoing Green is continuously increasing (See Figure 6).

Figure 6. Echoing Green Fellows' Organization Model (2008-2017)

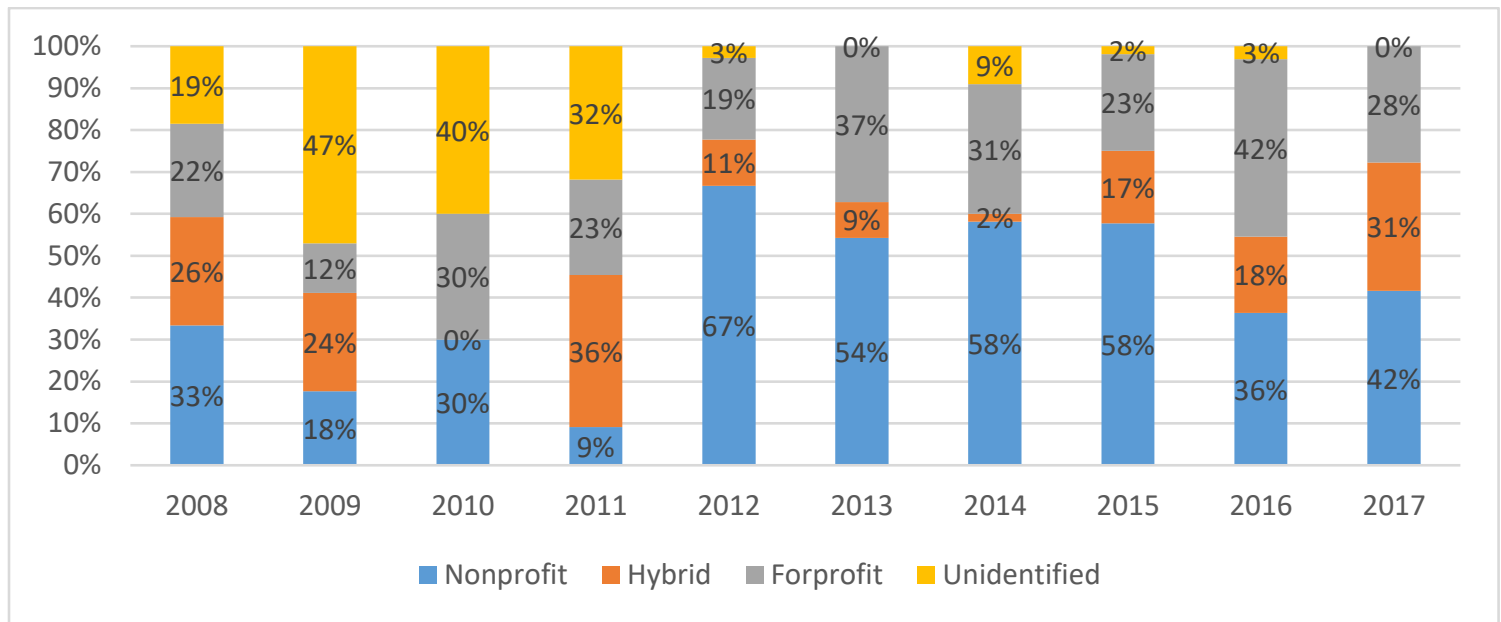

Note. The first Fellow to apply with a for-profit business model was selected in 2007.

Additionally, Echoing Green launched additional fellowship programs in partnership with other philanthropic foundations. It reflects the President Cheryl Dorsey's willingness to shift Echoing Green's strategy from one focused on a single program to a platform strategy that operated programs in many different areas (Battilana et al., 2015). In 2011, Echoing Green began working with The Social Entrepreneurs Fund (TSEF) in order to offer some of for-profit organizations recoverable grants, a form of convertible note that the organization require to repay the grant to TSEF when they become financially successful (Battilana, DeLong, and Weber, 2015). TSEF also provided additional follow-up capital for social entrepreneurs if they need it. In the same year, the ratio of for-profit/hybrid Fellows exceeds that of nonprofit Fellows. Among the entire Fellows, $58 \%$ of social ventures were engaging in economic activities for profit generation at least to some extent. 
Figure 7. Number of Fellows Selected by Year and Organization Model

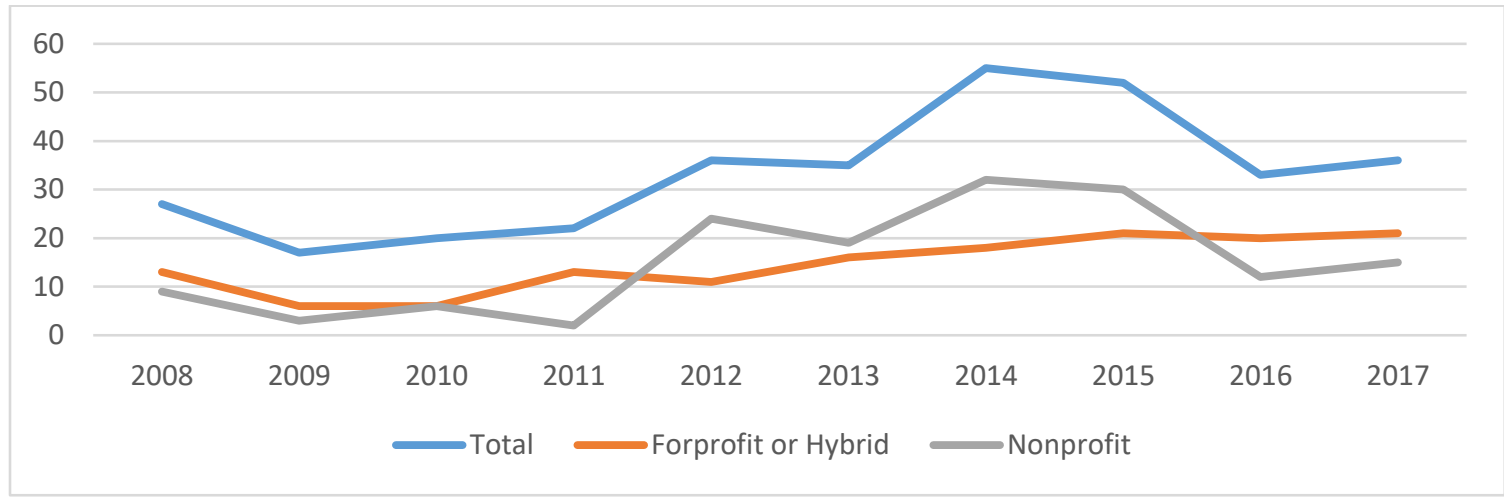

Source: Echoing Green website (www.echoinggreen.org)

Figure 8. GDP growth of the United States from 2008-2017

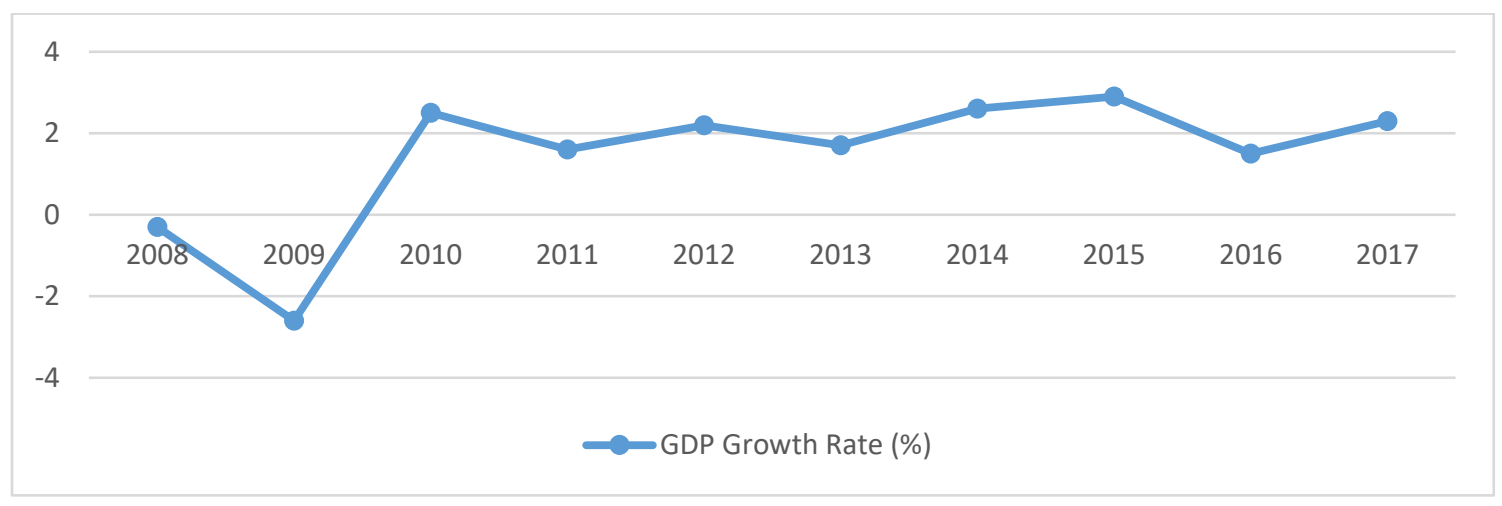


In 2012, Echoing Green formed a partnership with the Open Society Foundations in order to launch a new fellowship program called the Black Male Achievement (BMA) Fellowship. The Open Society Foundations is founded by George Soros in 1979, for originally supporting scholarships for black students at the University of Cape Town in South African and for Eastern European dissidents to study abroad. In 1996, the foundations launched programs in the United States, which focused on eradicating the root causes of poverty and injustice. The foundations have been promoting democratic governance and protecting the rights of minorities, and civil and political liberties. For the BMA Fellowship, the Open society foundations provided the funding and Echoing Green managed the program. The BMA fellows have diverse backgrounds, experience, and identities but share a common vision of addressing the most engrained problems facing black men and boys. Nine fellows were selected as the first BMA fellows in 2012, and most of them took nonprofit business model. As a result, the ratio of fellows relied on nonprofit model exceeds those relied on for-profit/hybrid model in 2012.

In 2013, Echoing Green created a partnership with Newman's Own Foundation. Newman's Own Foundation is a private foundation founded in in 2005 by Paul Newman, an actor and one of co-founder of Newman's Own, to sustain his philanthropic legacy. Echoing Green Fellows in 2013 are supported by Newman's Own Foundation through a partnership with Echoing Green. Newman's Own Foundation had been one of major donors of Echoing Green in 2013 and 2014.

Additionally, Echoing Green launched a new fellowship program called the Climate Fellowship in partnership with the ZOOM Foundation in 2014. The ZOOM Foundation is a private foundation that focuses its investments on innovative efforts that 
have high potential for sustainable and substantial social impact. The foundation concentrates its funding on projects in the areas of education and environment. The new Climate Fellowship is specifically targeted for next-generation social entrepreneurs working on innovations in mitigation and adaptation to climate change. In 2014, twelve social entrepreneurs are named as the first Climate Fellows. From 2014 to 2018, sixty-six Fellows committed to mitigate and adapt to climate changes are supported by Echoing Green.

Now in 2018, Echoing Green is operating three Fellowships: Global Fellowship, Black Male Achievement Fellowship, and Climate Fellowship. Global Fellowship has the longest history and is open to any social entrepreneurs with innovative ideas to tackle the social problem for any issue. Black Male Achievement Fellowship is given to leaders committed to improving the life of black men in the United States. Lastly, Climate Fellowship is for leaders with innovative ideas to face climate change. 
Table 5. Major Donators (Represents donors who contributed $\$ \mathbf{5 0 0 , 0 0 0}$ or more in that fiscal year)

\begin{tabular}{|c|c|c|c|c|c|c|c|}
\hline 2010 & 2011 & 2012 & 2013 & 2014 & 2015 & 2016 & 2017 \\
\hline $\begin{array}{l}\text { David C. } \\
\text { and Laurie } \\
\text { B. } \\
\text { Hodgson }\end{array}$ & $\begin{array}{l}\text { David C. } \\
\text { and Laurie } \\
\text { B. } \\
\text { Hodgson }\end{array}$ & $\begin{array}{l}\text { David C. } \\
\text { and Laurie } \\
\text { B. } \\
\text { Hodgson }\end{array}$ & $\begin{array}{l}\text { David C. } \\
\text { and Laurie } \\
\text { B. } \\
\text { Hodgson }\end{array}$ & Barclays & Barclays & $\begin{array}{l}\text { David C. } \\
\text { and Laurie } \\
\text { B. } \\
\text { Hodgson }\end{array}$ & Barclays \\
\hline $\begin{array}{l}\text { General } \\
\text { Atlantic }\end{array}$ & $\begin{array}{l}\text { General } \\
\text { Atlantic }\end{array}$ & $\begin{array}{l}\text { General } \\
\text { Atlantic }\end{array}$ & $\begin{array}{l}\text { General } \\
\text { Atlantic }\end{array}$ & $\begin{array}{l}\text { David C. } \\
\text { and Laurie } \\
\text { B. } \\
\text { Hodgson }\end{array}$ & $\begin{array}{l}\text { David C. } \\
\text { and Laurie } \\
\text { B. } \\
\text { Hodgson }\end{array}$ & $\begin{array}{l}\text { General } \\
\text { Atlantic }\end{array}$ & $\begin{array}{l}\text { David C. } \\
\text { and Laurie } \\
\text { B. } \\
\text { Hodgson }\end{array}$ \\
\hline $\begin{array}{l}\text { Pershing } \\
\text { Square } \\
\text { Foundation }\end{array}$ & $\begin{array}{l}\text { Pershing } \\
\text { Square } \\
\text { Foundation }\end{array}$ & $\begin{array}{l}\text { Open } \\
\text { Society } \\
\text { Foundation }\end{array}$ & $\begin{array}{l}\text { Newman's } \\
\text { Own } \\
\text { Foundation }\end{array}$ & $\begin{array}{l}\text { General } \\
\text { Atlantic }\end{array}$ & $\begin{array}{l}\text { General } \\
\text { Atlantic }\end{array}$ & JLGreene & $\begin{array}{l}\text { General } \\
\text { Atlantic }\end{array}$ \\
\hline \multirow[t]{7}{*}{$\begin{array}{l}\text { W.K. } \\
\text { Kellogg } \\
\text { Foundation }\end{array}$} & $\begin{array}{l}\text { W.K. } \\
\text { Kellogg } \\
\text { Foundation }\end{array}$ & $\begin{array}{l}\text { Pershing } \\
\text { Square } \\
\text { Foundation }\end{array}$ & $\begin{array}{l}\text { Open } \\
\text { Society } \\
\text { Foundation }\end{array}$ & $\begin{array}{l}\text { Irene } \\
\text { Diamond } \\
\text { Fund }\end{array}$ & JLGreene & $\begin{array}{l}\text { Open } \\
\text { Society } \\
\text { Foundation }\end{array}$ & JLGreene \\
\hline & & $\begin{array}{l}\text { W.K. } \\
\text { Kellogg } \\
\text { Foundation }\end{array}$ & $\begin{array}{l}\text { Pershing } \\
\text { Square } \\
\text { Foundation }\end{array}$ & JLGreene & $\begin{array}{l}\text { Open } \\
\text { Society } \\
\text { Foundation }\end{array}$ & $\begin{array}{l}\text { Steve and } \\
\text { Roberta } \\
\text { Denning }\end{array}$ & $\begin{array}{l}\text { Steve and } \\
\text { Roberta } \\
\text { Denning }\end{array}$ \\
\hline & & & & $\begin{array}{l}\text { Newman's } \\
\text { Own } \\
\text { Foundation }\end{array}$ & $\begin{array}{l}\text { Steve and } \\
\text { Roberta } \\
\text { Denning }\end{array}$ & USAID & $\begin{array}{l}\text { Zoom } \\
\text { Foundation }\end{array}$ \\
\hline & & & & $\begin{array}{l}\text { Open } \\
\text { Society } \\
\text { Foundation }\end{array}$ & USAID & $\begin{array}{l}\text { Walton } \\
\text { Family } \\
\text { Foundation }\end{array}$ & \\
\hline & & & & $\begin{array}{l}\text { Pershing } \\
\text { Square } \\
\text { Foundation }\end{array}$ & $\begin{array}{l}\text { Walton } \\
\text { Family } \\
\text { Foundation }\end{array}$ & $\begin{array}{l}\text { Zoom } \\
\text { Foundation }\end{array}$ & \\
\hline & & & & USAID & $\begin{array}{l}\text { Zoom } \\
\text { Foundation }\end{array}$ & & \\
\hline & & & & $\begin{array}{l}\text { Zoom } \\
\text { Foundation }\end{array}$ & & & \\
\hline
\end{tabular}

Source: Echoing Green Annual Reports (2010-2017). 


\section{CHANGES OF BOARD COMPOSITION}

As the number of partnerships increases, the size of Echoing Green board grows. In 2008, it has seventeen board members, while in 2018 it has twenty four members. David C. Hodgson from General Atlantic has been a Chairman since 2008, and Maya Ajmera, a former Echoing Green Fellow in 1993, became the vice chair in 2010. In 2014, she became the Co-Chair of the board. Echoing Green Fellows had not attended the board except Ajmera and the president Cheryl Dorsey, but recently two former Fellows, Rafiq Kalam Id-Din at Ember Charter Schools and Raj Panjabi at Last Mile Heath became new board members. Currently in 2018, Echoing Green has four board member who are former Echoing Green Fellows. Among twenty four members in 2016, nine serve as board members since 2008.

In 2008, the board was balanced in terms of board members' backgrounds. Among fifteen members, eight members were from social sector, while nine members were from commercial sector, particularly investment banking. However, after the economic downturn in 2008 , new members joined the board were heavily from financial sectors. From 2008 to 2013, Echoing Green brought six new board members from financial institutions, including Ajay Nagpal at Barclays in 2011. During that time, the only new board member with non-financial background was Joshua Mailman at Social Venture Network in 2013. To enhance the base of donors and create partnerships with other foundations, Echoing Green increased the size of the board, and brought in people at financial institutions. From 2010 to 2013, Echoing Green board was dominated by directors from financial institutions. 
However, in 2016, three new board members with social sector background attended the board. Rafiq Kalam Id-Din and Raj Panjabi are former Echoing Green Fellows in 2007 and 2011 accordingly, and Peggy Segal is program director of Hunter College in New York. Seemingly, Echoing Green strive for balancing the background of board members after its financial situations became relatively stable in 2016 .

Surprisingly, when most of board members were from financial institutions, Echoing Green supported more nonprofit social ventures over for-profit/hybrid ventures, except in the year of 2011. On the other hand, after new members with social sector background came to the board, the ratio of Fellows relying on for-profit/hybrid model became exceed that of Fellows relying on nonprofit model. It could be partially interpreted as being consistent with the motives for corporate giving (Peterson \& Su, 2017) that had been largely examined in organization literature. Research on corporate philanthropy suggested that foundations sponsored by industrial-oriented firms tend to make charitable giving decisions more from an altruistic purpose, while foundations sponsored by consumer-oriented firms has marketing-related objective to increase sales through philanthropy (Peterson \& Su, 2017). Expectedly, the primary goal of financial institutions might improve their public image by engaging in philanthropy, rather than increase its sales or financial performance. Like industrial-oriented firms, thus, board of directors represent financial institutions would put much emphasis on charitable purpose of giving. This argument is based on the observation of just one case but opens an interesting research question that future research can investigate. 


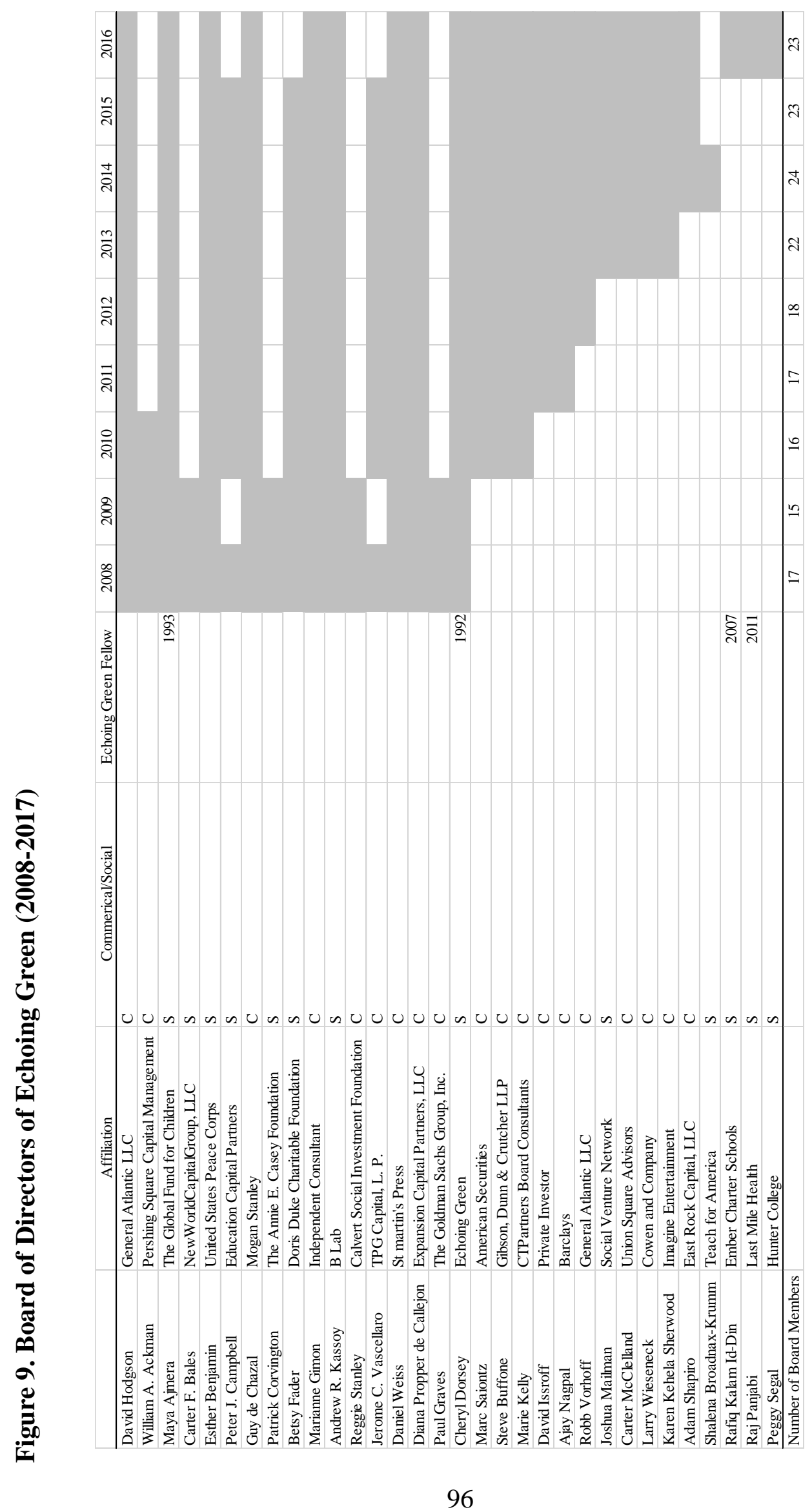




\section{CHANGES IN CHARACTERISTICS OF FELLOWS}

The chart represents the number of Echoing Green Fellows on yearly basis shows similar pattern with that of the GDP growth rate of the United States (Figure 2-1, Figure 2-2). During the economic downturn in 2008-2009, the GDP growth rate and the number of Echoing Green Fellows show similar trajectory. Additionally, when the GDP growth rate increased in 2014, the number of Fellows also increased. While, when the GDP growth rate decreased in 2016, the number of Fellows selected were also decreased, and in 2017, both of them increased again. These graphs look largely different in 2010 and 2011, when the GDP growth rate highly increased while the number of Fellows were still low. It might indicate that there exists a time lag between the improvement of macroeconomic conditions and that of Fellowship foundations' charitable giving. Echoing Green has been slowly increasing the number of Fellows after the economic downturn in 2008-2009.

Echoing Green supports social entrepreneurs with innovative ideas to solve social problems in the area of arts \& culture, civil \& human rights, education, environment, food \& agriculture, health \& healthcare, poverty alleviation \& economic development, and public service $\&$ civic engagement. Fellows were mainly operated in education, environment, and poverty alleviation \& economic development. The number of Fellows in environment and poverty alleviation has continually increased, while that in education showed the same pattern until 2015 and significant decreased in 2016 and 2017. The number of Fellows in environment highly increased after 2014, when the Climate Fellowship was launched. The number of Fellows aiming to alleviate poverty or develop economic situation was the highest in 2008, while it significantly fell down in 2009 , 
assumingly due to the influence of the financial crisis. However, after 2009, the number increased again.

Figure 10. Issue Areas of Echoing Green Fellows by Year

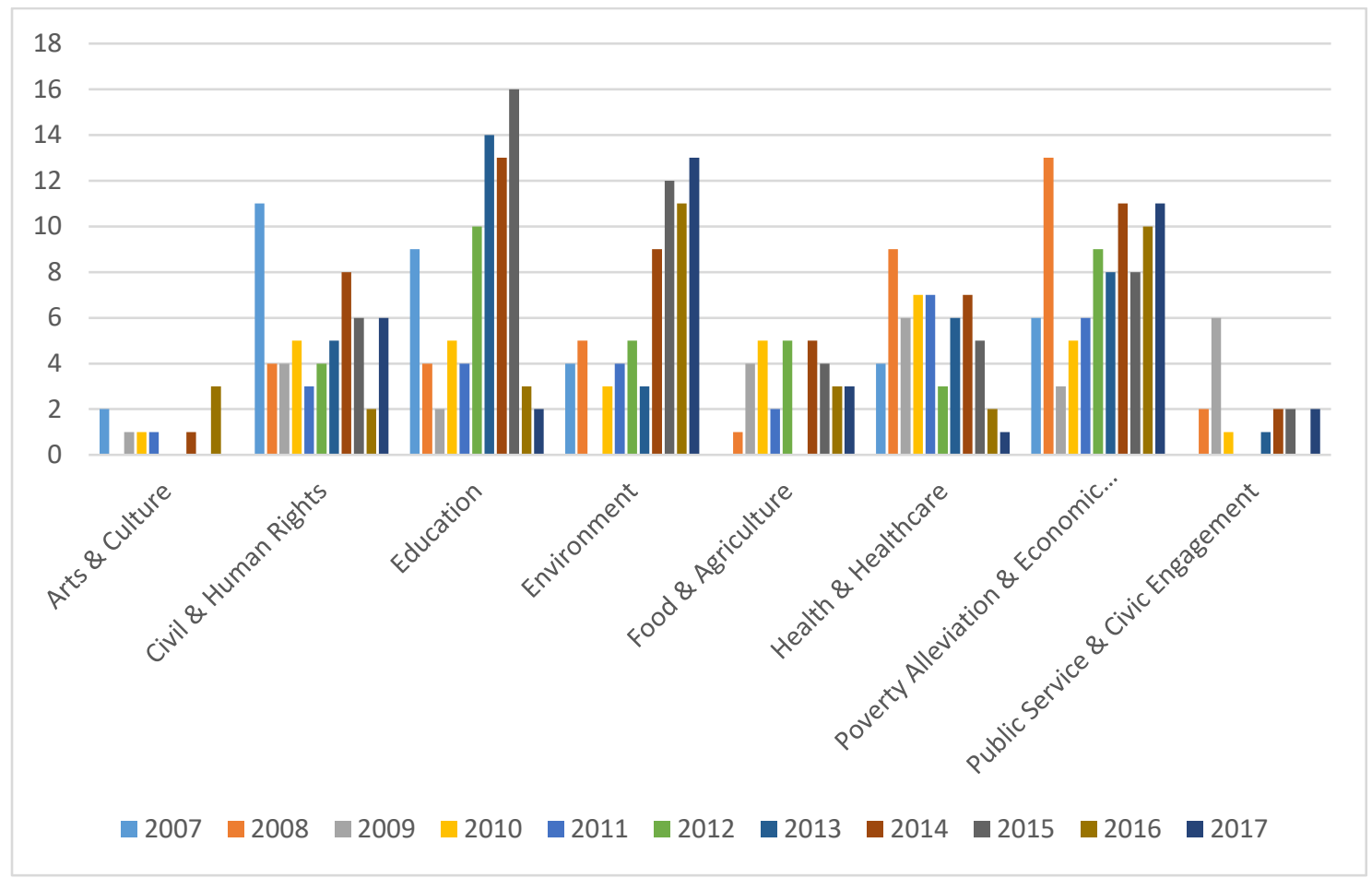

\begin{tabular}{|c|c|c|c|c|c|c|c|c|c|c|c|}
\hline & 2007 & 2008 & 2009 & 2010 & 2011 & 2012 & 2013 & 2014 & 2015 & 2016 & 2017 \\
\hline Arts \& Culture & 2 & 0 & 1 & 1 & 1 & 0 & 0 & 1 & 0 & 3 & 0 \\
\hline Civil \& Human Rights & 11 & 4 & 4 & 5 & 3 & 4 & 5 & 8 & 6 & 2 & 6 \\
\hline Education & 9 & 4 & 2 & 5 & 4 & 10 & 14 & 13 & 16 & 3 & 2 \\
\hline Environment & 4 & 5 & 0 & 3 & 4 & 5 & 3 & 9 & 12 & 11 & 13 \\
\hline Food \& Agriculture & 0 & 1 & 4 & 5 & 2 & 5 & 0 & 5 & 4 & 3 & 3 \\
\hline Health \& Healthcare & 4 & 9 & 6 & 7 & 7 & 3 & 6 & 7 & 5 & 2 & 1 \\
\hline Poverty Alleviation \& Economic Development & 6 & 13 & 3 & 5 & 6 & 9 & 8 & 11 & 8 & 10 & 11 \\
\hline Public Service \& Civic Engagement & 0 & 2 & 6 & 1 & 0 & 0 & 1 & 2 & 2 & 0 & 2 \\
\hline
\end{tabular}




\section{IMPLICATIONS OF ECHOING GREEN'S STRATEGIC CHOICE}

To overcome the financial adversity in 2008, Echoing Green took two major strategic decisions. 1) Building a base of donors by selecting new board members at financial institutions. 2) Creating a partnership with private foundations and cooperatively launch and support fellowship programs. By implementing these strategies, the President Cheryl Dorsey can enhance the finances of the foundation and achieve the vision she had about the fellowship platform. Additionally, Echoing Green continuously provides increasing supports to social entrepreneurs rely on for-profit/hybrid model. It has been emphasizing the importance of sustainability for social ventures.

However, some people in philanthropy have raised concerns about the recent tendency of fellowship foundations highlighting for-profit/hybrid model and using venture-capitalist approach to select social ventures to support. They argued that foundations for social entrepreneurship do not provide resources to people who really need the resources, especially those who were eliminated from opportunities to get the college education. For instance, most of Echoing Green Fellows were young college graduates, and a number of them had a chance to attend the social entrepreneur incubating program in their Universities, specifically designed for developing skills and knowledge about the social entrepreneurship. As a result, they know how to frame their work look innovative, how to use appropriate language in the application, and how to do better presentation. Therefore, they can have better chance of getting funding than people in arduous situations who desperately need resources to improve their living conditions. 
For thirty years, Echoing Green had supported more than 763 social change leaders working in 86 countries, directly invested $\$ 42.5$ million in their development, and created substantial and sustainable social changes. Echoing Green Fellows had been widely successful so far, but there is still a remaining question. One of board members of Echoing Green once asked, "Whether we were really making our fellows successful, or were we simply picking great fellows who will be successful with or without them? (Battilana et al., 2009)." Fellowship foundations need to be better supporting social entrepreneurs from all backgrounds to more effectively create meaningful social changes. 


\section{CHAPTER 5: CONCLUSIONS}

The purpose of this research is to provide useful insights to understand early-stage social ventures' resource acquisition and the first CEO selection, and the survival strategy of funding organizations for early-stage social ventures. Drawing upon insights from signaling theory and team diversity literature, the proposed framework in Chapter 2 describes factors that affect impact investors' investment decisions, and how these factors are created during the formation of social ventures. In doing so, the framework explicates the criteria VPFs tend to rely on when they select social ventures to support. Additionally, it highlights a social entrepreneur's personal experience related to the motivation of starting a social venture as a crucial resource of an early-stage social venture, which can indirectly affect the funding success rate in the early stage. The proposed model has particular implications for social entrepreneurs who are in a nascent stage of organizational development and aim to acquire financial resources and strategic support from impact investors. Suggestions for this research can contribute to early-stage social ventures' chance to succeed in VPFs funding.

The empirical study in Chapter 3 investigates the first CEO selection in earlystage social ventures, where members of groups determine who might be best suited as the first CEO. Findings show that the first CEO selection in this context differs from that in another entrepreneurship context. It indicates that distinctive characteristics of social ventures from other organizations contribute to the unique leadership emergence pattern in early-stage social ventures. Specifically, when core founders had previously worked in social sectors, they were most likely to be perceived as leaders. Additionally, women entrepreneurs' commercial experience is much favorably considered than men 
entrepreneurs' commercial experience in the first CEO selection. By looking into how leadership emerges in early-stage social venture context, it provides implications for scholars interested in leadership emergence or CEO selection in the entrepreneurship context. Additionally, it might be of interest to early-stage social entrepreneurs who compete for the first CEO position. Findings of this chapter also have implications for funding organizations that aim to create concrete social changes by supporting social entrepreneurs with capability and credibility.

Finally, Chapter 4 explores the survival strategy of the Echoing Green Foundation, one of the prominent impact investors that primarily support social ventures in a nascent stage. To overcome the challenge emerged from the financial crisis in 2008, the Echoing Green foundation create many partnerships to improve its economic status and successfully transform itself from a single funding program to a platform which supports a variety of social mission. These strategic decisions lead to significant changes in its board construction and thus have an impact on the type of social ventures that the Echoing Green mainly supports. The Echoing Green's story offers valuable implications for public charities, and private foundations aim to support social entrepreneurship.

While the proposed models and stories in this dissertation offer useful insights to understand decision makings of early-stage social ventures and impact investors, there is still room for improvement. One limitation of this dissertation is its concentration on only for-profit and hybrid ventures, which bounds the generalizability of findings. I believe exploring the proposed model using a different dataset would contribute to the literature by adding richer implications. For instance, nonprofit social ventures can show a different pattern in their leader selection and resource acquisition from for-profit or hybrid social 
ventures. Furthermore, this dissertation suggests a social entrepreneur's personal experience that facilitates founding motivation as an important resource for early-stage social ventures yet does not dig into enough to figure out how does this affect the social entrepreneur's decision-making pattern and outcomes of social venture. For years, some social entrepreneurship scholars have tapped into this topic, but the long-term effect of social entrepreneurs' personal experience with the social problem is not widely studied so far. I believe future research can create a significant contribution to social entrepreneurship literature by further delving into this concept by taking many different approaches.

In this dissertation, I intend to extend the literature on early-stage social ventures and impact investors. Overall, findings suggest that social ventures, especially in its early-stage, provide a unique context to investigate organizational topics, and their distinctive characteristics mainly affect resource acquisition and the CEO selection. It indicates promising future research opportunities for scholars in the field of social entrepreneurship. I also believe that policymakers and practitioners will benefit significantly from additional research examining social entrepreneurship. 


\section{REFERENCES}

Ai, C., \& Norton, E. C. (2003). Interaction terms in logit and probit models. Economics Letters, 80(1), 123-129.

Altman, D. G. (1991). Mathematics for kappa. Practical Statistics for Medical Research, 406-407.

Alvord, S. H., Brown, L. D., \& Letts, C. W. (2004). Social entrepreneurship and Societal Transformation. The Journal of Applied Behavioral Science, 40(3), 260-282.

Amabile, T. M. (1996). Creativity in context: Update to" the social psychology of creativity." Westview Press.

Appelbaum, S. H., Audet, L., \& Miller, J. C. (2003). Gender and leadership? Leadership and gender? A journey through the landscape of theories. Leadership \& Organization Development Journal, 24(1), 43-51.

Austin, J., Stevenson, H., \& Wei-Skillern, J. (2006). Social and commercial entrepreneurship: same, different, or both? Entrepreneurship theory and practice, 30(1), 1-22.

Bamford, C. E., Dean, T. J., \& McDougall, P. P. (2000). An examination of the impact of initial founding conditions and decisions upon the performance of new bank startups. Journal of Business Venturing, 15(3), 253-277.

Baron, J. N., Hannan, M. T., \& Burton, M. D. (1999). Building the iron cage: Determinants of managerial intensity in the early years of organizations. American Sociological review, 527-547.

Baron, J. N., Hannan, M. T., Hsu, G., \& Koçak, Ö. (2007). In the company of women: Gender inequality and the logic of bureaucracy in start-up firms. Work and Occupations, 34(1), 35-66.

Bart, C. K., Bontis, N., \& Taggar, S. (2001). A model of the impact of mission statements on firm performance. Management Decision, 39(1), 19-35.

Barton Rabe, C. (2006). How leaders use Zero-Gravity Thinkers to stimulate innovation. Strategy \& Leadership, 34(6), 38-43.

Bass, B. M., Avolio, B. J., \& Atwater, L. (1996). The transformational and transactional leadership of men and women. Applied Psychology: An International Review, 45(1), $5-34$.

Battilana, J., DeLong, T. J., \& Weber, J. (2009). Echoing Green. Harvard Business School Case 410-013, July 2009. 
Battilana, J., DeLong, T., \& Weber, J. Leadership at Echoing Green. Harvard Business School Case 412-090, March 2012. (Revised January 2015.)

Battilana, J., \& Dorado, S. (2010). Building sustainable hybrid organizations: The case of commercial microfinance organizations. Academy of Management Journal, 53(6), 1419-1440.

Battilana, J., \& Lee, M. (2014). Hybrid organizing - Insights from the study of social enterprises. The Academy of Management Annals, 8(1), 397-441.

Battilana, J., Lee, M., Walker, J., \& Dorsey, C. (2012). In search of the hybrid ideal. Stanford Social Innovation Review, 10(3), 50-55.

Becker, G. S. (1975). Human capital. A theoretical and empirical analysis with special reference to education. The National Bureau of Economic Research, 3, 1-22.

Beckman, C. M. (2006). The influence of founding team company affiliations on firm behavior. Academy of Management Journal, 49(4), 741-758.

Beckman, C. M., \& Burton, M. D. (2008). Founding the future: Path dependence in the evolution of top management teams from founding to IPO. Organization science, 19(1), 3-24.

Beckman, C. M., Burton, M. D., \& O'Reilly, C. (2007). Early teams: The impact of team demography on VC financing and going public. Journal of Business Venturing, 22(2), 147-173.

Berger, J., \& Fişek, M. H. (2006). Diffuse status characteristics and the spread of status value: A formal theory. American Journal of Sociology, 111(4), 1038-1079.

Bettencourt, B. A., \& Charlton, K., Dorr, N., Hume, D. L. (2001). Status differences and In-group bias : A meta- analytic examination of the effects of status stability, status legitimacy , and group permeability. Psychological Bulletin.

Bettenhausen, K. L. (1991). Five years of groups research: What we have learned and what needs to be addressed. Journal of Management, 17(2), 345-381.

Bugg-Levine, A., Kogut, B., \& Kulatilaka, N. (2012). A new approach to funding social enterprises. Harvard business review, 90(1/2), 118-123.

Bunderson, J. S., \& Sutcliffe, K. M. (2002). Comparing alternative conceptualizations of functional diversity in management teams: Process and performance effects. Academy of management Journal, 45(5), 875-893.

Burke, A. E., FitzRoy, F. R., \& Nolan, M. A. (2000). When less is more: distinguishing between entrepreneurial choice and performance. Oxford Bulletin of Economics and Statistics, 62(5), 565-587.

Burt, R., \& Reagans, R. (1997). Homophily, legitimacy, and competition: Bias in manager peer evaluations. Chicago Management Council. 
Buttner, E. ., \& Rosen, B. (1989). Funding new business ventures: Are decision makers blased against women entrepreneurs? Journal of Business Venturing, 4, 249-261.

Cannella, A. A., Park, J. H., \& Lee, H. U. (2008). Top management team functional background diversity and firm performance: Examining the roles of team member colocation and environmental uncertainty. Academy of Management Journal, 51(4), 768-784.

Cannella, A. A., \& Shen, W. (2001). So close and yet so far: Promotion versus exit for CEO heirs apparent. Academy of Management Journal, 44(2), 252-270.

Chowdhury, S. (2005). The role of affect-and cognition-based trust in complex knowledge sharing. Journal of Managerial issues, 310-326.

Chen, G., Liu, C., \& Tjosvold, D. (2005). Conflict management for effective top management teams and innovation in China. Journal of Management Studies, 42(2), 277-300.

Chen, Y.-R., Peterson, R. S., Phillips, D. J., Podolny, J. M., \& Ridgeway, C. L. (2012). Introduction to the special issue: Bringing status to the table-Attaining, maintaining, and experiencing status in organizations and markets. Organization Science, 23(2), 299-307.

Connelly, B. L., Certo, S. T., Ireland, R. D., \& Reutzel, C. R. (2011). Signaling theory: A review and assessment. Journal of Management, 37(1), 39-67.

Crotts, J. C., Dickson, D. R., \& Ford, R. C. (2005). Aligning organizational processes with mission: The case of service excellence. The Academy of Management Executive, 19(3), 54-68.

Cummings, J. N. (2004). Work groups, structural diversity, and knowledge sharing in a global organization. Management Science, 50(3), 352-364.

Dahlin, K. B., Weingart, L. R., \& Hinds, P. J. (2005). Team diversity and information use. Academy of Management Journal, 48(6), 1107-1123.

Daily, C. M., Certo, S. T., \& Dalton, D. R. (2005). Investment bankers and IPO pricing: does prospectus information matter? Journal of Business Venturing, 20(1), 93111.

D’Aveni, R. A. (1990). Top managerial prestige and organizational bankruptcy. Organization Science, 1(2), 121-142.

Davidsson, P., \& Honig, B. (2003). The role of social and human capital among nascent entrepreneurs. Journal of Business Venturing, 18(3), 301-331.

Dees, J. G. (1998). The meaning of social entrepreneurship.

Dees, J. G., \& Anderson, B. (2003). For-profit social ventures. International Journal of Entrepreneurship Education, 2(1), 1-26. 
Dencker, J. C., Gruber, M., \& Shah, S. K. (2009). Individual and opportunity factors influencing job creation in new firms. Academy of Management Journal, 52(6), 1125-1147.

Der Foo, M., Wong, P. K., \& Ong, A. (2005). Do others think you have a viable business idea? Team diversity and judges' evaluation of ideas in a business plan competition. Journal of Business Venturing, 20(3), 385-402.

Dimitriadis, S., Lee, M., Ramarajan, L., \& Battilana, J. (2017). Blurring the boundaries: The interplay of gender and local communities in the commercialization of social ventures. Organization Science, 28(5), 819-839.

Dimov, D. (2010). Nascent entrepreneurs and venture emergence: Opportunity confidence, human capital, and early planning. Journal of Management Studies, 47(6), 1123-1153.

Dimov, D., \& Murray, G. (2008). Determinants of the incidence and scale of seed capital investments by venture capital firms. Small Business Economics, 30(2), 127-152.

Dimov, D. P., \& Shepherd, D. A. (2005). Human capital theory and venture capital firms: Exploring "home runs" and "strike outs." Journal of Business Venturing, 20(1), 121.

Dokko, G., Wilk, S. L., \& Rothbard, N. P. (2009). Unpacking Prior Experience: How Career History Affects Job Performance. Organization Science, 20(1), 51-68.

Dougherty, D. (1992). Interpretive barriers to successful product innovation in large firms. Organization Science, 3(2), 179-202.

Drucker, P. F. (1985). Innovation and entrepreneurship practices and principles. AMACON.

Eagly, A. H., \& Karau, S. J. (1991). Gender and the Emergence of Leaders: A MetaAnalysis. Journal of Personality and Social Psychology, 60(5), 685-710.

Ebrahim, A., Battilana, J., \& Mair, J. (2014). The governance of social enterprises: Mission drift and accountability challenges in hybrid organizations. Research in Organizational Behavior, 34(November), 81-100.

Echoing Green Annual Reports, 2008-2017.

Edmondson, A. (1999). Psychological safety and learning behavior in work teams. Administrative science quarterly, 44(2), 350-383.

Eesley, C. E., Hsu, D. H., \& Roberts, E. B. (2014). The contingent effects of top management teams on venture performance: Aligning founding team composition with innovation strategy and commercialization environment. Strategic Management Journal, 35(12), 1798-1817. 
Eisenhardt, K. M., \& Schoonhoven, C. B. (1990). Organizational Growth: Linking Founding team, strategy, environment, and growth among US semiconductor ventures, 1978-1988. Administrative science quarterly, 504-529.

Elitzur, R., \& Gavious, A. (2003). Contracting, signaling, and moral hazard: a model of entrepreneurs, 'angels,'and venture capitalists. Journal of Business Venturing, 18(6), 709-725.

Ensley, M. D., Carland, J. C., Carland, J. W., \& Banks, M. (1999). Exploring the existence of entrepreneurial teams. International Journal of Management, 16, 276-293.

Estrin, S., Mickiewicz, T., \& Stephan, U. (2016). Human capital in social and commercial entrepreneurship. Journal of Business Venturing, 31(4), 449-467.

Fain, P. 2016. Inside Higher Ed "Foundations and Political Influence". Inside Higher Ed. https://www.insidehighered.com/news/2016/07/20/author-discusses-new-bookshifts-how-foundations-seek-shape-public-policy, July 20, 2016.

Fern, M. J., Cardinal, L. B., \& O'Neill, H. M. (2012). The genesis of strategy in new ventures: escaping the constraints of founder and team knowledge. Strategic Management Journal, 33(4), 427-447.

Finkelstein, S. (2001). Power in top management teams : and Validation. The Academy of Management Journal, 35(3), 505-538.

Fleiss, J. L. (1981). The Measurement of Interrater Agreement. Statistical Methods for Rates and Proportions, 2nd edn pp 212-304.

Forbes, D. P., Borchert, P. S., Zellmer-Bruhn, M. E., \& Sapienza, H. J. (2006). Entrepreneurial team formation: An exploration of new member addition. Entrepreneurship Theory and Practice, 30(2), 225-248.

Francis, D. H., \& Sandberg, W. R. (2000). Friendship within entrepreneurial teams and its association with team and venture performance. Entrepreneurship: Theory and Practice, 25(2), 5-5.

Fraser, S. L., \& Lord, R. G. (1988). Stimulus prototypicality and general leadership impressions: Their role in leadership and behavioral ratings. Journal of Psychology: Interdisciplinary and Applied.

Fuller-Love, N., Lim, L., \& Akehurst, G. (2006). Guest editorial: Female and ethnic minority entrepreneurship. International Entrepreneurship and Management Journal, 2(4), 429-439.

Garg, S. A. M., Eisenhardt, K. M., Sutton, B., Reilly, C. O., Byers, T., Seelig, T., ... Beckman, C. (2017). Unpacking the CEO - Board Relationship: How Strategy Making Happens in Entrepreneurial Firms. Academy of Management Journal, 60(5), $1828-1858$. 
Germak, A. J., \& Robinson, J. A. (2014). Exploring the motivation of nascent social entrepreneurs. Journal of Social Entrepreneurship, 5(1), 5-21.

Gimeno, J., Folta, T. B., Cooper, A. C., \& Woo, C. Y. (1997). Survival of the Fittest? Entrepreneurial Human Capital and the Persistence of Underperforming Firms, Administrative Science Quarterly, 42(4), 750-783.

Gimmon, E., \& Levie, J. (2010). Founder's human capital, external investment, and the survival of new high-technology ventures. Research Policy, 39(9), 1214-1226.

Gompers, P. A., \& Lerner, J. (1999). What drives venture capital fundraising? (No. w6906). National bureau of economic research.

Green, E., \& Galinsky, L. (2018). Be Bold-A Movement Begins with an Idea. In Creating a New Civilization Through Social Entrepreneurship (pp. 109-114). Routledge.

Gruber, M. (2010). Exploring the origins of organizational paths: Empirical evidence from newly founded firms. Journal of Management, 36(5), 1143-1167.

Gupta, V. K., Turban, D. B., Wasti, S. A., \& Sikdar, A. (2009). The role of gender stereotypes in perceptions of entrepreneurs and intentions to become an entrepreneur. Entrepreneurship: Theory and Practice, 33(2), 397-417.

Guthrie, J. P., \& Datta, D. K. (1997). Contextual Influences on Executive Selection: Firm Characteristics and Ceo Experience. Journal of Management Studies, 34(4), 537560 .

Gwet, K. L. (2014). Handbook of inter-rater reliability: The definitive guide to measuring the extent of agreement among raters. Advanced Analytics, LLC.

Hamilton, R. W., \& Thompson, D. V. (2007). Is there a substitute for direct experience? Comparing consumers' preferences after direct and indirect product experiences. Journal of Consumer Research, 34(4), 546-555.

Harding, R. (2007). State of Women's Enterprise in the UK.

Hartmann, D. P. (1977). Considerations in the choice of interobserver reliability estimates. Journal of Applied Behavior Analysis, 10(1), 10-103.

Heilman, M. E. (2012). Gender stereotypes and workplace bias. Research in Organizational Behavior, 32, 113-135.

Hellmann, T., \& Wasserman, N. (2017). The First Deal: The Division of Founder Equity in New Ventures. Management Science, 63(8), 2647-2666.

Hinds, P. J., \& Mortensen, M. (2005). Understanding conflict in geographically distributed teams: The moderating effects of shared identity, shared context, and spontaneous communication. Organization Science, 16(3), 290-307. 
Hoetker, G. (2007). The Use of Logit and Probit Models in Strategic Management Research: Ctirical Issues. Strategic Management Journal, 331-343.

Horwitz, S. K., \& Horwitz, I. B. (2007). The effects of team diversity on team outcomes: A meta-analytic review of team demography. Journal of Management, 33(6), 987-1015.

Hsu, D. H. (2007). Experienced entrepreneurial founders, organizational capital, and venture capital funding. Research Policy, 36(5), 722-741.

Huang, L., \& Pearce, J. L. (2015). Managing the unknowable: The effectiveness of earlystage investor gut feel in entrepreneurial investment decisions. Administrative Science Quarterly, 60(4), 634-670.

Huang, L., \& Knight, A. P. (2017). Resources and relationships in entrepreneurship: an exchange theory of the development and effects of the entrepreneur-investor relationship. Academy of Management Review, 42(1), 80-102.

Janus, K. (2018). Opinion: Steps Foundations Can Take to Give Women and People of Color a Chance to Build Great Nonprofits, The Chronicle of Philanthropy, online published.

Jehn, K. A., Northcraft, G. B., \& Neale, M. A. (1999). Why differences make a difference: A field study of diversity, conflict and performance in workgroups. Administrative science quarterly, 44(4), 741-763.

Johnson, V. (2007). What is organizational imprinting? Cultural entrepreneurship in the founding of the Paris Opera1. American Journal of Sociology, 113(1), 97-127.

Jung, H. (2017). How Do Entrepreneurial Founding Teams Allocate Task Positions? Academy of Management Journal, 60(1), 264-294.

Jussim, L., Coleman, L. M., \& Lerch, L. (1987). The Nature of Stereotypes: A Comparison and Integration of Three Theories. Journal of Personality and Social Psychology, 52(3), 536-546.

Kanter, R. M. (1988). Three tiers for innovation research. Communication Research, 15(5), 509-523.

Kaplan, S. N., Sensoy, B. A., \& Strömberg, P. (2009). Should investors bet on the jockey or the horse? Evidence from the evolution of firms from early business plans to public companies. The Journal of Finance, 64(1), 75-115.

Kark, R. (2004). The transformational leader: Who is (s)he? A feminist perspective. Journal of Organizational Change Management, 17(2), 160-176.

Kark, R., Waismel-Manor, R., \& Shamir, B. (2012). Does valuing androgyny and femininity lead to a female advantage? The relationship between gender-role, transformational leadership and identification. Leadership Quarterly, 23(3), 620640. 
Kim, P. H., \& Longest, K. C. (2014). You can't leave your work behind Employment experience and founding collaborations. Journal of Business Venturing, 29(6), 785-806.

Kor, Y. Y. (2003). Experience-based top management team competence and sustained growth. Organization Science, 14(6), 707-719.

Lanaj, K., \& Hollenbeck, J. R. (2015). Leadership over-emergence in self-managing teams: The role of gender and countervailing biases. Academy of Management Journal, 58(5), 1476-1494.

Larson, A., \& Starr, J. A. (1993). A network model of organization formation. Entrepreneurship: Theory and Practice, 17(2), 5-16.

Lazear, E. P. (2004). Balanced skills and entrepreneurship. The American Economic Review, 94(2), 208-211.

Lee, M., \& Huang, L. (2018). Gender Bias, Social Impact Framing, and Evaluation of Entrepreneurial Ventures. Organization Science, 29(1), 1-16.

Lee, P. M., \& James, E. H. (2007). SHE'-E-OS: Gender effects and investor reactions to the announcements of top executive appointments. Strategic Management Journal, 28(3), 227-241.

Levinthal, W. M. . C. and D. A. (1989). Innovation and Learning: The Two Faces of R \& D Published by: Wiley on behalf of the Royal Economic Society Stable. The Economic Journal, 99(397), 569-596.

Liberman, N., Trope, Y., \& Stephan, E. (2007). Psychological distance. Social psychology: Handbook of basic principles, 2, 353-383.

Lovelace, K., Shapiro, D. L., \& Weingart, L. R. (2001). Maximizing cross-functional new product teams' innovativeness and constraint adherence: A conflict communications perspective. Academy of management Journal, 44(4), 779-793.

Lumpkin, G. T., \& Dess, G. G. (1996). Clarifying the entrepreneurial orientation construct and linking it to performance. Academy of Management Review, 21(1), 135-172.

Lumpkin, G. T., Moss, T. W., Gras, D. M., Kato, S., \& Amezcua, A. S. (2013). Entrepreneurial processes in social contexts: How are they different, if at all? Small Business Economics, 40(3), 761-783.

Lyon, D. W., Lumpkin, G. T., \& Dess, G. G. (2000). Enhancing entrepreneurial orientation Research: Operationalizing and measuring a key strategic decision making process. Journal of Management, 26(5), 1055-1085.

Magnusson, P., \& Boggs, D. J. (2006). International experience and CEO selection: An empirical study. Journal of International Management, 12(1), 107-125.

Mair, J., \& Martí, I. (2006). Social entrepreneurship research: A source of explanation, prediction, and delight. Journal of World Business, 41(1), 36-44. 
Mazzola, E., Perrone, G., \& Kamuriwo, D. S. (2015). Network embeddedness and new product development in the biopharmaceutical industry: The moderating role of open innovation flow. International Journal of Production Economics, 160, 106119.

McEvily, B., Perrone, V., \& Zaheer, A. (2003). Trust as an organizing principle. Organization Science, 14(1), 91-103.

Mchugh, M. L. (n.d.). Lessons in biostatistics Interrater reliability: the kappa statistic, 276-282.

McPherson, M., Smith-Lovin, L., \& Cook, J. M. (2001). Birds of a feather: Homophily in social networks. Annual review of sociology, 415-444.

Marquis, C., \& Tilcsik, A. (2013). Imprinting: Toward a multilevel theory. The Academy of Management Annals, 7(1), 195-245.

Mathias, B. D., Williams, D. W., \& Smith, A. R. (2015). Entrepreneurial inception: The role of imprinting in entrepreneurial action. Journal of Business Venturing, 30(1), 11-28.

Meyskens, M., Robb-Post, C., Stamp, J. A., Carsrud, A. L., \& Reynolds, P. D. (2010). Social ventures from a Resource-Based Perspective: An exploratory study assessing global Ashoka fellows. Entrepreneurship theory and practice, 34(4), 661-680.

Miles, R. E., \& Snow, C. C. (1984). Designing strategic human resources systems. Organizational Dynamics, 13(1), 36-52.

Miller, T. L., Grimes, M. G., McMullen, J. S., \& Vogus, T. J. (2012). Venturing for Others With Heart and Head: How Compassion Encourages Social Entrepreneurship. Academy of Management Review, 37(4), 616-640.

Miller, T. L., Wesley, I. I., \& Curtis, L. (2010). Assessing mission and resources for social change: An organizational identity perspective on social venture capitalists' decision criteria. Entrepreneurship Theory and Practice, 34(4), 705-733.

Morris, M. H., Coombes, S., Schindehutte, M., \& Allen, J. (2007). Antecedents and outcomes of entrepreneurial and market orientations in a non-profit context: Theoretical and empirical insights. Journal of Leadership \& Organizational Studies, 13(4), 12-39.

Moss, T. W., Neubaum, D. O., \& Meyskens, M. (2015). The effect of virtuous and entrepreneurial orientations on microfinance lending and repayment: A signaling theory perspective. Entrepreneurship Theory and Practice, 39(1), 27-52.

Neubert, M. J., \& Taggar, S. (2004). Pathways to informal leadership: The moderating role of gender on the relationship of individual differences and team member network centrality to informal leadership emergence. Leadership Quarterly, 15(2), 175-194. 
Nicholls, A. (2006). Playing the field: A new approach to the meaning of social entrepreneurship. Social Enterprise Journal, 2(1), 1-5.

Nijstad, B. A., \& De Dreu, C. K. (2002). Creativity and group innovation. Applied Psychology, 51(3), 400-406.

Norton, E. C., Wang, H., \& Ai, C. (2004). Computing Interaction Effects and Standard Errors in Logit and Probit Models. Stata Journal, 4(2), 154-167.

Peredo, A. M., \& McLean, M. (2006). Social entrepreneurship: A critical review of the concept. Journal of world business, 41(1), 56-65.

Perrini, F., \& Vurro, C. (2006). Social entrepreneurship: Innovation and social change across theory and practice. In Social entrepreneurship (pp. 57-85). Palgrave Macmillan UK.

Peterson, D. K., \& Su, Y. (2017). Relationship between Corporate Foundation Giving and the Economic Cycle for Consumer-and Industrial-Oriented Firms. Business \& Society, 56(8), 1169-1194.

Pomerantz, M. (2003). The business of social entrepreneurship in a" down economy". IN BUSINESS-EMMAUS PENNSYLVANIA-, 25(2), 25-28.

Prentice, D. A., \& Carranza, E. (2002). What Women and Men Should Be, Shouldn ' T

Be, Are Allowed To Be , and Don' T Have To Be : the Contents of Prescriptive Gender Stereotypes. Psychology of Women Quarterly, 26, 269-281.

Randjelovic, J., O'Rourke, A. R., \& Orsato, R. J. (2003). The emergence of green venture capital. Business strategy and the environment, 12(4), 240-253.

Ridgeway, C. L. (2001). Gender, Status , and Leadership, 57(4), 637-655.

Ridgeway, C. L., \& Correll, S. J. (2004). Unpacking the gender system a theoretical perspective on gender beliefs and social relations. Gender and Society, 18(4), $510-531$.

Robinson, J. (2006). Navigating social and institutional barriers to markets: How social entrepreneurs identify and evaluate opportunities. Social Entrepreneurship, 95-120.

Rosener, J. B., \& Rosener, J. B. (n.d.). Women Lead. Harvard Business Review, 119126.

Ruef, M., Aldrich, H. E., \& Carter, N. M. (2003). The structure of founding teams: Homophily, strong ties, and isolation among US entrepreneurs. American sociological review, 195-222.

Scarlata, M., \& Alemany, L. (2009). How do philanthropic venture capitalists choose their portfolio companies? Society, 1-23.

Scarlata, M., Zacharakis, A., \& Walske, J. (2016). The effect of founder experience on 
the performance of philanthropic venture capital firms. International Small Business Journal: Researching Entrepreneurship, 34(5), 618-636.

Schaumberg, R. L., \& Flynn, F. J. (2017). Self-reliance: A Gender Perspective on its Relationship to Communality and Leadership Evaluations. Academy of Management Journal, 60(5), 1859-1881.

Semler, S. W. (1997). Systematic agreement: A theory of organizational alignment. Human Resource Development Quarterly, 8(1), 23.

Sen, P. (2007). Ashoka's big idea: Transforming the world through social entrepreneurship. Futures, 39(5), 534-553.

Shane, S. (1995). Uncertainty avoidance and the preference for innovation championing roles. Journal of International Business Studies, 26(1), 47-68.

Shane, S., \& Khurana, R. (2003). Bringing individuals back in: the effects of career experience on new firm founding. Industrial and Corporate Change, 12(3), 519543.

Shane, S., Locke, E. A., \& Collins, C. J. (2003). Entrepreneurial motivation. Human Resource Management Review, 13(2), 257-279.

Shane, S., \& Venkataraman, S. (2000). The promise of entrepreneurship as a field of research. Academy of management review, 25(1), 217-226.

Shin, S. J., Kim, T. Y., Lee, J. Y., \& Bian, L. (2012). Cognitive team diversity and individual team member creativity: A cross-level interaction. Academy of Management Journal, 55(1), 197-212.

Short, J. C., Moss, T. W., \& Lumpkin, G. T. (2009). Research in social entrepreneurship: Past contributions and future opportunities. Strategic entrepreneurship journal, 3(2), 161-194.

Smith, K. G., Smith, K. A., Olian, J. D., Sims Jr, H. P., O'Bannon, D. P., \& Scully, J. A. (1994). Top management team demography and process: The role of social integration and communication. Administrative science quarterly, 412-438.

Spence, M. (2002). Signaling in retrospect and the informational structure of markets. The American Economic Review, 92(3), 434-459.

Stevenson, H. H., Roberts, M. J., \& Grousbeck, H. I. (1989). Business ventures and the entrepreneur. Irwin, Homewood, IL.

Stiglitz, J. E. (2000). The contributions of the economics of information to twentieth century economics. Quarterly Journal of Economics, 1441-1478.

Tajfel, H. (1974). Social identity and intergroup behaviour. Social Science Information/sur les sciences sociales.

Tajfel, H. (1981). Human groups and social categories: Studies in social psychology. CUP Archive. 
Taylor, A., \& Greve, H. R. (2006). Superman or the fantastic four? Knowledge combination and experience in innovative teams. Academy of Management Journal, 49(4), 723-740.

Teasdale, S., Mckay, S., Phillimore, J., \& Teasdale, N. (2011). enterprises, 2(1), 57-76.

Tichy, Noel M. Managing strategic change: Technical, political, and cultural dynamics. Vol. 3. John Wiley \& Sons, 1983.

Toft-Kehler, R., Wennberg, K., \& Kim, P. H. (2014). Practice makes perfect: Entrepreneurial-experience curves and venture performance. Journal of Business Venturing, 29(4), 453-470.

Ucbasaran, D., Lockett, A., Wright, M., \& Westhead, P. (2003). Entrepreneurial founder teams: Factors associated with member entry and exit. Entrepreneurship Theory and Practice, 28(2), 107-128.

Unger, J. M., Rauch, A., Frese, M., \& Rosenbusch, N. (2011). Human capital and entrepreneurial success: A meta-analytical review. Journal of Business Venturing, 26(3), 341-358.

Wagner, J. (2006). Are nascent entrepreneurs 'Jacks-of-all-trades'? A test of Lazear's theory of entrepreneurship with German data. Applied Economics, 38(20), 24152419.

Wasserman, N. (2012). The founder's dilemmas: Anticipating and avoiding the pitfalls that can sink a startup. Princeton University Press.

Wasserman, N. (2016). The throne vs. the kingdom: Founder control and value creation in startups. Strategic Management Journal.

Wegge, J., Roth, C., Neubach, B., Schmidt, K. H., \& Kanfer, R. (2008). Age and gender diversity as determinants of performance and health in a public organization: the role of task complexity and group size. Journal of Applied Psychology, 93(6), 1301.

Wellman, N. (2017). Authority or community? A relational models theory of group-level leadership emergence. Academy of Management Review, 42(4), 596-617.

Westphal, J. D., \& Fredrickson, J. W. (2001). Who directs strategic change? Director experience, the selection of new CEOs, and change in corporate strategy. Strategic Management Journal, 22(12), 1113-1137.

Wiklund, J., \& Shepherd, D. (2005). Entrepreneurial orientation and small business performance: a configurational approach. Journal of business venturing, 20(1), 71-91.

Williams, K. Y., \& O'Reilly III, C. A. (1998). DEMOGRAPHY AND. Research in organizational behavior, 20, 77-140. 
Woodman, R. W., Sawyer, J. E., \& Griffin, R. W. (1993). Toward a theory of organizational creativity. Academy of management review, 18(2), 293-321.

Wry, T., \& York, J. G. (2017). An Identity-Based Approach to Social Enterprise. The Academy of Management Review, 42(3), 437-460.

Yitshaki, R., \& Kropp, F. (2016). Entrepreneurial passions and identities in different contexts: a comparison between high-tech and social entrepreneurs. Entrepreneurship \& Regional Development, 28(3-4), 206-233.

Zacharakis, A. L., \& Meyer, G. D. (1998). A lack of insight: do venture capitalists really understand their own decision process? Journal of business venturing, 13(1), 5776.

Zahra, S. A., Nielsen, A. P., \& Bogner, W. C. (1999). Corporate entrepreneurship, knowledge, and competence development. Entrepreneurship: Theory and Practice, 23(3), 169-169.

Zhang, Y. A. N., \& Rajagopalan, N. (2003). Explaining New Ceo Origin : Academy of Management Journal, 46(3), 327-338.

Zheng, Y. (2012). Unlocking founding team prior shared experience: A transactive memory system perspective. Journal of Business Venturing, 27(5), 577-591. 


\section{APPENDIX}

\section{Coding Guideline}

Please thoroughly read given materials (Echoing Green Profile, LinkedIn Profile, Articles) about each founding team member, founding team, and venture, and code the applicable information on the given excel spreadsheet.

1. Read the description of each concept and understand it before you start coding.

2. I have provided examples of the coding of three ventures and venture teams. Please examine those to see how the coding works.

\section{Core founder, other founders, CEO}

- Definition: A core founder is an individual who comes up with the idea of creating the organization and suggests the earliest outline of the venture (Wasserman, 2012; 2017). In some cases, the core founder can be more than one person.

- Non-core founders are the ones who joined the core founder as part of the team.

- The CEO is a member of the founding team who is the highest ranking individual in that team.

\begin{tabular}{|l|l|l|}
\hline Variables & Definition & Coding \\
\hline Core founder & $\begin{array}{l}\text { An individual who comes up } \\
\text { with the idea of creating the } \\
\text { organization and suggests the } \\
\text { earliest outline of the venture }\end{array}$ & $\begin{array}{l}0=\text { Non-Core founder } \\
1=\text { Core founder }\end{array}$ \\
\hline CEO & $\begin{array}{l}\text { Job title: CEO/ Executive } \\
\text { director/ Managing director/Other } \\
\text { title represents the highest } \\
\text { position in the venture }\end{array}$ & $\begin{array}{l}0=\text { Non-CEO } \\
1=\text { CEO }\end{array}$ \\
\hline
\end{tabular}

\section{Commercial experience}

a. Definition: prior working experiences at commercial companies.

i. Commercial company: A company that has to follow normal accepted business practices and operates in order to make a profit (From Longman Business Dictionary) 


\begin{tabular}{|c|c|c|}
\hline Variables & Definition & Coding \\
\hline CE_Month & $\begin{array}{l}\text { Months spent on working at } \\
\text { commercial companies }\end{array}$ & Number $(0 \sim N)$ \\
\hline CE_Type & $\begin{array}{l}\text { Nature of work experiences at } \\
\text { commercial companies; } \\
\text { (Check all that apply) or } \\
\text { (Write down all applicable } \\
\text { numbers) }\end{array}$ & $\begin{array}{l}\text { 1= Venture capital experience } \\
2=\text { Financial experience } \\
3=\text { Senior management } \\
\text { experience } \\
4=\text { Consulting experience } \\
5=\text { Entrepreneurial experience- } \\
\text { founder of a commercially } \\
\text { motivated firm } \\
6=\text { Entrepreneurial experience- } \\
\text { employee of a commercially } \\
\text { motivated firm (startup) } \\
7=\text { Employee of a } \\
\text { commercially motivated firm } \\
\text { (non-startup) } \\
8=\text { Others }\end{array}$ \\
\hline $\begin{array}{l}\text { CE_Background } \\
\text { (Column 1,2,3) }\end{array}$ & $\begin{array}{l}\text { Function of work experiences at } \\
\text { commercial companies } \\
\text { (In the 'CE_background_1 } \\
\text { column, report the most recent } \\
\text { experience, to CE_background_2 } \\
\text { the second most recent, and so } \\
\text { forth) }\end{array}$ & $\begin{array}{l}1=\text { Production and Operations } \\
2=\text { R\&D and Engineering } \\
3=\text { Accounting and Finance } \\
4=\text { Management and } \\
\text { Administration } \\
5=\text { Marketing and Sales } \\
6=\text { Law } \\
7=\text { Personnel and Labor } \\
\text { relations } \\
8=\text { Others }\end{array}$ \\
\hline CE_F500 & $\begin{array}{l}\text { Had worked at least one Fortune } \\
500 \text { company } \\
\text { (Use this link for assessment: } \\
\text { http://fortune.com/fortune500/list/) }\end{array}$ & $1=$ Yes $0=$ No \\
\hline CE_Serial & $\begin{array}{l}\text { The number of commercial } \\
\text { companies an individual has } \\
\text { founded in the past }\end{array}$ & Number $(0 \sim N)$ \\
\hline
\end{tabular}

\section{Social experience}

a. Definition: prior working experiences at organizations with a primary social aim (a non-profit, for profit, or hybrid)

\begin{tabular}{|l|l|l|}
\hline Variables & Definition & Coding \\
\hline SE_Month & $\begin{array}{l}\text { Months spent on working at } \\
\text { organizations with a primary social } \\
\text { aim }\end{array}$ & Number $(0 \sim \mathrm{N})$ \\
\hline
\end{tabular}




\begin{tabular}{|c|c|c|}
\hline SE_Type & $\begin{array}{l}\text { Nature of work experiences at } \\
\text { organizations with a primary social } \\
\text { aim } \\
\text { (Check all that apply) or } \\
\text { (Write down all applicable numbers) }\end{array}$ & $\begin{array}{l}\text { 1= Social venture capital } \\
\text { (SVC) or Philanthropic } \\
\text { venture capital (PhVC) } \\
\text { experience } \\
2=\text { Senior management } \\
\text { experience at an } \\
\text { organization with a } \\
\text { primary social aim } \\
\text { 3= Experiences working } \\
\text { for the government or } \\
\text { government agencies } \\
\text { 4= Entrepreneurial } \\
\text { experience-founder of an } \\
\text { organization with a } \\
\text { primary social aim } \\
\text { 5= Entrepreneurial } \\
\text { experience- employee of } \\
\text { an organization with a } \\
\text { primary social aim } \\
\text { (startup) } \\
6=\text { Employee of an } \\
\text { organization with a } \\
\text { primary social aim (non- } \\
\text { startup) } \\
7=\text { Others }\end{array}$ \\
\hline $\begin{array}{l}\text { SE_Background } \\
\text { (Column 1,2,3) }\end{array}$ & $\begin{array}{l}\text { Function of working experiences at } \\
\text { organizations with a primary social } \\
\text { aim } \\
\text { (In the 'SE_background_1 column, } \\
\text { report the most recent experience, to } \\
\text { SE_background_2 the second most } \\
\text { recent, and so forth) }\end{array}$ & $\begin{array}{l}1=\text { Production and } \\
\text { Operations } \\
2=\mathrm{R} \& \mathrm{D} \text { and Engineering } \\
3=\text { Accounting and } \\
\text { Finance } \\
\text { 4= Management and } \\
\text { Administration } \\
5=\text { Marketing and Sales } \\
6=\text { Law } \\
7=\text { Personnel and Labor } \\
\text { relations } \\
8=\text { Others }\end{array}$ \\
\hline SE_Scope & $\begin{array}{l}\text { The regional scope of the organization } \\
\text { with a primary social aim } \\
\text { (Check all that apply) or } \\
\text { (Write down all applicable numbers) }\end{array}$ & $\begin{array}{l}1=\text { Local } \\
2=\text { National } \\
3=\text { Global }\end{array}$ \\
\hline SE_Serial & $\begin{array}{l}\text { The number of organizations with a } \\
\text { primary social aim that an individual } \\
\text { has founded in past }\end{array}$ & Number $(0 \sim N)$ \\
\hline
\end{tabular}




\section{Research experience}

a. Definition: Prior research experience at an educational institution (mostly at University)

\begin{tabular}{|c|c|c|}
\hline Variables & Definition & Coding \\
\hline RE_Month & $\begin{array}{l}\text { Months spent on working as an } \\
\text { independent researcher/research } \\
\text { assistant at an educational institution }\end{array}$ & Number $(0 \sim \mathrm{N})$ \\
\hline RE_Institution & $\begin{array}{l}\text { Educational institution that an } \\
\text { individual conducted a research at/ } \\
\text { Sponsor of the research program } \\
\text { (Check all that apply) or } \\
\text { (Write down all applicable numbers) }\end{array}$ & $\begin{array}{l}0=\text { None } \\
1=\text { High school } \\
2=\text { University } \\
3=\text { Government } \\
4=\text { Others }\end{array}$ \\
\hline RE_Elite School & $\begin{array}{l}\text { An individual conducted research at } \\
\text { an elite school }{ }^{3} \\
\text { (Use the school where an individual } \\
\text { most recently worked for this } \\
\text { assessment) }\end{array}$ & $\begin{array}{l}0=\text { Non-elite school } \\
1=\text { Elite school }\end{array}$ \\
\hline
\end{tabular}

\section{Balanced entrepreneurs}

\begin{tabular}{|l|l|l|}
\hline Variables & Definition & Coding \\
\hline $\begin{array}{l}\text { Balanced } \\
\text { entrepreneur }\end{array}$ & $\begin{array}{l}\text { He or she had more than 12 months } \\
\text { of work experiences in both } \\
\text { commercial and social area. }\end{array}$ & $\begin{array}{l}0=\text { Non-balanced } \\
\text { entrepreneur } \\
1=\text { Balanced entrepreneur }\end{array}$ \\
\hline
\end{tabular}

\section{Demographic information}

\begin{tabular}{|l|l|}
\hline Variables & Coding \\
\hline Gender & $0=$ Male, $1=$ Female \\
\hline Age & $\begin{array}{l}\text { Year of undergraduate college graduation } \\
\text { (e.g. Class of 2018 } \rightarrow \text { Write down 2018) }\end{array}$ \\
\hline
\end{tabular}

\footnotetext{
${ }^{3}$ See A for the list of elite schools
} 


\begin{tabular}{|c|c|}
\hline $\begin{array}{l}\text { Undergrad major (Column } \\
1,2 \text { ) } \\
\text { (Identify the individual's } \\
\text { major or the first listed of } \\
\text { several majors and enter } \\
\text { that in UG_M-1; if the } \\
\text { individual had a minor, or a } \\
\text { second major, enter that in } \\
\text { column UG_M-2) }\end{array}$ & $\begin{array}{l}0=\text { None } \\
1=\text { Computer science/mathematics } \\
2=\text { Life sciences (agricultural and food, biological, and } \\
\text { environmental life sciences) } \\
3=\text { Physical sciences (chemistry except biochemistry, } \\
\text { earth science, geology, oceanography, physics, and } \\
\text { astronomy) } \\
\text { 4=Social sciences (economics, political science, } \\
\text { psychology, sociology, and anthropology) } \\
\text { 5=Engineering (aerospace, chemical, civil and } \\
\text { architectural, electrical, industrial, and mechanical) } \\
6=\text { Humanities (languages, literatures, philosophy, } \\
\text { religion) } \\
7=\text { Arts } \\
8=\text { Law } \\
9=\text { Medical finance, accounting, } \\
\text { 10=Business administration } \\
\text { management, marketing, entrepreneurship) }\end{array}$ \\
\hline Undergrad elite school $^{4}$ & $\begin{array}{l}0=\text { Non-elite university } \\
1=\text { Elite university }\end{array}$ \\
\hline $\begin{array}{l}\text { Grad major (Column 1,2) } \\
\text { (Identify the individual's } \\
\text { major or the first listed of } \\
\text { several majors and enter } \\
\text { that in GS_M-1; if the } \\
\text { individual had a minor, or a } \\
\text { second major, enter that in } \\
\text { column GS_M-2) }\end{array}$ & $\begin{array}{l}0=\text { None } \\
\text { 1=Computer science/mathematics } \\
2=\text { Life sciences (agricultural and food, biological, and } \\
\text { environmental life sciences) } \\
3=\text { Physical sciences (chemistry except biochemistry, } \\
\text { earth science, geology, oceanography, physics, and } \\
\text { astronomy) } \\
\text { 4=Social sciences (economics, political science, } \\
\text { psychology, sociology, and anthropology) } \\
\text { 5=Engineering (aerospace, chemical, civil and } \\
\text { architectural, electrical, industrial, and mechanical) } \\
6=\text { Humanities (languages, literatures, philosophy, } \\
\text { religion) } \\
7=\text { Arts } \\
8=\text { Law } \\
9=\text { Medical finance, accounting, } \\
\text { 10=Business administration } \\
\text { management, marketing, entrepreneurship) }\end{array}$ \\
\hline 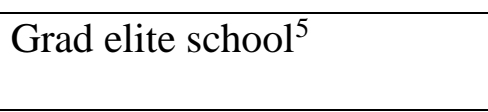 & $\begin{array}{l}0=\text { Non-elite university } \\
1=\text { Elite university }\end{array}$ \\
\hline
\end{tabular}

${ }^{4}$ See A for the list of elite schools.

${ }^{5}$ See A for the list of elite schools. 


\begin{tabular}{|l|l|}
\hline Highest level of completed & 0=None \\
education & 1=High school \\
& 2=Community college \\
& 3=Bachelor \\
& 4=Master \\
& 5=Higher professional degrees \\
\hline Professional degree & 0=None \\
& 1=Medical doctor (M.D.); Doctor of Dental Surgery \\
& (DDS) \\
& 2=MBA \\
& 3=Juris Doctor (J.D.) \\
& 4=The Master of Laws (LL.M.) \\
& 5= Doctor of Theology (ThD) \\
& (Check all that apply) \\
& \\
\hline Nationality & 1= United States \\
& 2= North America outside of US \\
& 3= Latin America \\
& 4= Africa \\
& 5= Asia-Pacific \\
& 6=Europe \\
& 7= Middle East \\
\hline Race/Ethnicity & 1= White \\
& $0=$ Others \\
\hline
\end{tabular}

7. Primary motivation of engaging in social entrepreneurship

\begin{tabular}{|l|l|}
\hline Variables & Coding \\
\hline $\begin{array}{l}\text { Motivation that primarily } \\
\text { drives formation of the } \\
\text { current social venture }\end{array}$ & $\begin{array}{l}0=\text { No personal experience with the social problem } \\
1=\text { Having specific personal experiences with social } \\
\text { problem }\end{array}$ \\
\end{tabular}

\section{Team-level variables}

\begin{tabular}{|l|l|}
\hline Variables & Coding \\
\hline Founding team size & Number of founders \\
\hline
\end{tabular}

${ }^{6}$ See B for details. 


\section{Venture-level variables}

\begin{tabular}{|l|l|}
\hline Variables & Coding \\
\hline Country & Country the social venture operates in \\
\hline Model & 0= Hybrid 1=For-profit \\
\hline Issue Area & 1= Arts \& Culture \\
& 2= Civil \& Human rights \\
& 3= Education \\
& 4= Environment \\
& 5= Food \& Agriculture \\
& 6= Health \& Healthcare \\
& 7= Poverty alleviation \& Economic development \\
& 8= Public service \& Civic engagement \\
\hline
\end{tabular}




\section{A: Elite Education Institutions (Finkelstein, Academy of Management Journal, 1992)}

Amherst College, Brown University, Carleton College, Columbia University, Cornell University, Dartmouth College, Grinnell College, Harvard University, Haverford College, Johns Hopkins University, Massachusetts Institute of technology, New York University, Northwestern University, Oberlin College, Pomona College, Princeton University, Stanford University, Swarthmore College, United States Military Academy, United States Naval Academy, University of California, Berkeley, University of California, Los Angeles, University of Chicago, University of Michigan, University of Pennsylvania, Wellesley College, Wesleyan University, Williams College, Yale University

\section{B: Motivation that primarily drives formation of the current venture (Adapted from Yitshaki \& Kropp, Journal of Small Business Management, 2015)}

- Coding

$0=$ No personal experience with the social problem

$1=$ Having Specific personal experiences with the social problem

- Concept

- Social Entrepreneurs (SEs) in this category connect their motivations to emotional life events in the past or the present. The SEs experienced pain in the past, and each created a social venture that would help alleviate others from experiencing pain, shame, abuse, or confusion that they had experienced. They want to help individuals in similar circumstances.

- Examples

- A SE who developed a venture for educating disabled children: "My middle daughter suffers from cerebral palsy. Due to my disappointment with the national bureaucracy I decided that somebody should do something in order to assist parents of such children to cope with the difficulties."

- A SE who established a venture to support new immigrant families who became drug addicts as a result of her own experience: "look for women that experienced similar problem... I decided to organize them because when you are alone you are vulnerable but if you are unified as a group, you have power."

- A SE who established a venture to empower women through entrepreneurship education said her experience as a young divorced 
women guided her: "I thought that everything a woman needed is love... and then I found myself alone... I could never be active in this field without my experience... entrepreneurship can empower women... I transferred that love I had in my previous life to other women, to internal love." "I invest in my volunteers as if they were my best friends... it is like I am compensating myself from where I was hurt and I had a chance to correct it." (From Yitshaki \& Kropp, 2015) 


\section{VITA}

Nahyun Oh earned her B.A. in English Language Education from Seoul National University in 2011 and received an M.S. in Business Administration from Korea University in 2013. In 2018 she completed a Ph.D. in Business Administration from the Robert J. Trulaske, Sr. College of Business, University of Missouri-Columbia. Her primary research interests include entrepreneurial teams, social entrepreneurship, and team/organizational culture.

Her works are published in Human Resource Management and the Journal of Personnel Psychology. She is a member of the Academy of Management. Her research has been presented at several national and international conferences. She and her colleagues won the Douglas Nigh Award at IM division at the Annual Meeting of the AoM, Atlanta, 2017. She has taught the strategic management capstone courses for six semesters and the introductory entrepreneurship courses for two semesters. 